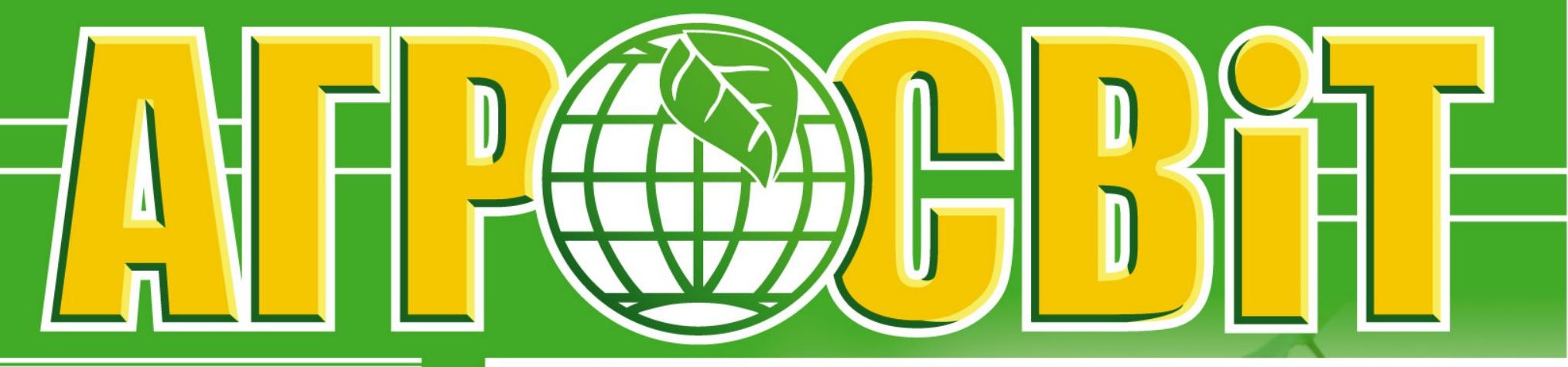

№19 жовтень 2021

Науково-практичнй журнал

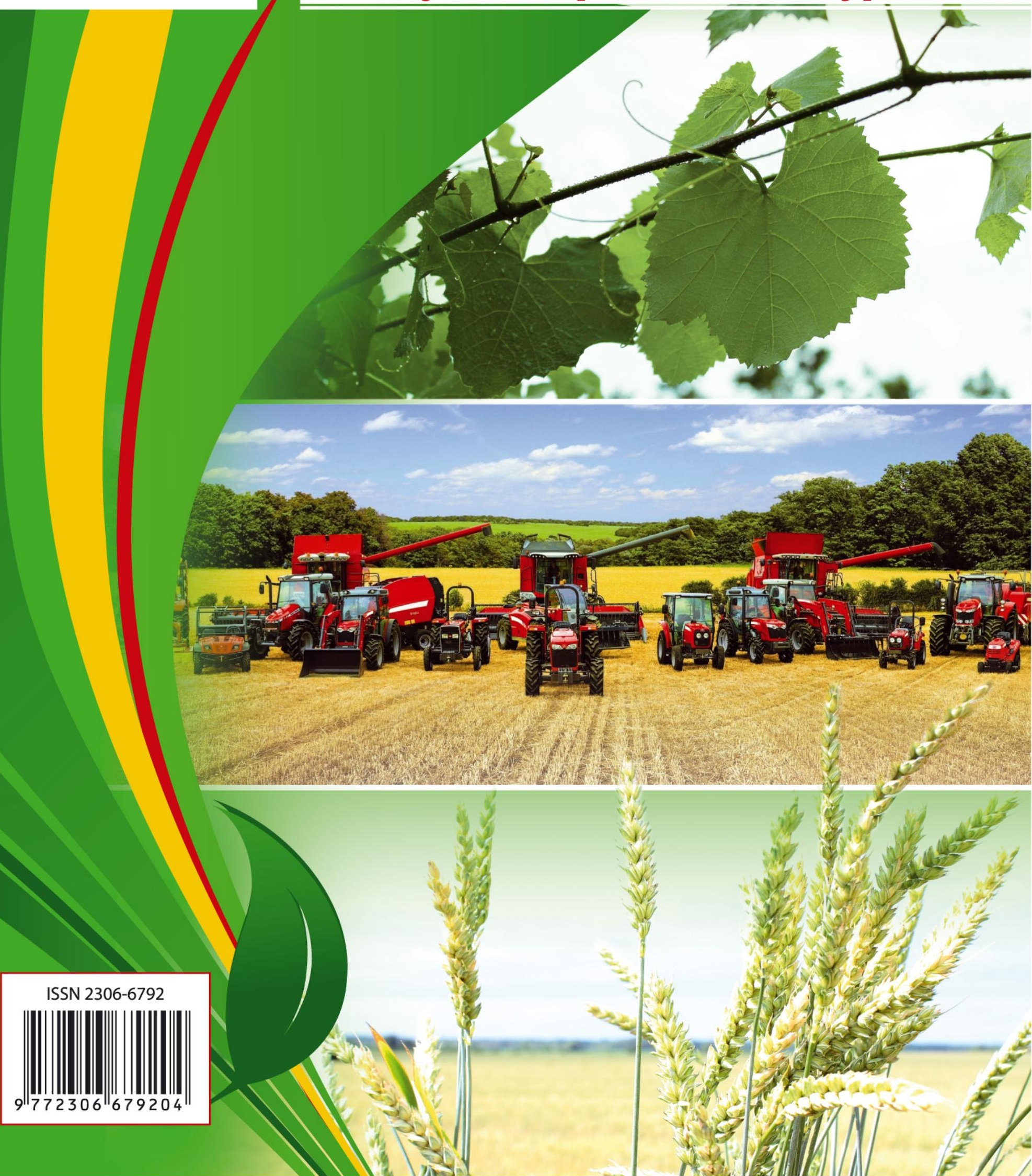


ГОАОВНИЙ РЕААКТОР:

Васильєва Наталя Костянтинівна, доктор економічних наук, професор, завідувач кафедри інформаційних систем і технологій, Аніпровський державний аграрно-економічний університет

ЗАСТУПНИК ГО АОВНОГО РЕААКТОРА: Вініченко Ігор Іванович, доктор економічних наук, професор, завідувач кафедри економіки, Аніпровський державний аграрно-економічний університет

ВІАПОВІАААЬНИЙ СЕКРЕТАР: Кучеренко Г. Б.

\section{ЧАЕНИ РЕААКЦІЙНОÏ КОАЕГІЇ:}

Анарющенко Катерина Анатоліївна, доктор економічних наук, доцент, професор кафедри економіки та підприємництва, $\triangle \mathrm{BH} 3$ «Київський національний економічний університет імені Вадима Гетьмана»

Безус Роман Миколайович, доктор економічних наук професор, професор кафедри маркетингу, Аніпровський державний аграрно-економічний університет

Гончаренко Оксана Володимирівна, доктор економічних наук, професор, професор кафедри економіки, Аніпровський державнии аграрно-економічний університет

Аобровальська Олена Володимирівна, доктор економічних наук, доцент, доцент кафедри фінансів, банківсько справи та страхування, Аніпровський державний аграрноекономічний університет

Козловський Сергій Володимирович, доктор економічних наук, професор, професор кафедри підприємництва корпоративної та просторової економіки, Аонецький національний університет імені Василя Стуса (м. Вінниця)

Каткова Наталя Володимирівна, кандидат економічних наук, доцент, професор кафедри обліку і економічного аналізу, Національний університет кораблебудування ім. адмірала Макарова

Качула Світлана Валентинівна, доктор економічних наук, доцент, професор кафедри фінансів, банківської справи та страхування, Аніпровський державний аграрноекономічний університет

Крючко Иеся Станіславівна, кандидат економічних наук, доцент, доцент кафедри маркетингу, Аніпровський державний аграрно-економічний університет

Кураташвілі Альфред Анзорович (Тбілісі, Грузія), доктор економічних, філософських юридичних наук, професор в галузі суспільних наук, професор Трузинського технічного університету в області Публічного права (Факультет Права і Міжнародних відносин), науковий керівник Інституту Бізнесу і Права факультетів Права і Міжнародних відносин і Бізнестехнологій ГТУ, завідувач відділом економічної теорії Інституту економіки імені П.Гугушвілі Тбіліського державного університету імені Іване Ажавахішвілі

Иозинський Амитро Иеонідович, кандидат економічних наук, доцент, доцент кафедри обліку і аудиту, Аержавний університет «Житомирська політехніка»

Павлова Галина Євгеніївна, доктор економічних наук, професор, професор кафедри обліку, оподаткування та управління фінансово-економічною безпекою, Аніпровський державний аграрно-економічний університет

Самойленко Алла Олександрівна, кандидат економічних наук, доцент кафедри менеджменту та туристичного бізнесу, Аніпровський національний університет імені Олеся Гончара

Пантєлєєва Наталія Миколаївна, доктор економічних наук, кандидат технічних наук, доцент, доцент кафедри фінансів та банківської сп рави, Черкаський навчально-науковий інститут Аержавного вищого навчального закладу «Університет банківської справи»

Трусова Наталя Вікторівна, доктор економічних наук, професор, професор кафедри фінансів, банківської справи та страхування Таврійського державного агротехнологічного університету, Таврійський державний агротехнологічний університет

Федоренко Станіслав Валентинович, кандидат технічних наук, доцент, доцент кафедри охорони праці і навколишнього середовища КНУБА, академік академії будівництва України

Халатур Світлана Миколаївна, доктор економічних наук, професор, професор кафедри фінансів, банківськоі справи та страхування, Аніпровський державний аграрноекономічний університет

Череп ОлексанАр Григорович, доктор економічних наук, доцент, професор кафедри економіки, Запорізький національний університет

Чирва Ольга Григорівна, доктор економічних наук, професор, професор кафедри маркетингу, менеджменту та управління бізнесом, Уманський державний педагогічний університет імені Павла Тичини

Шабатура Тетяна Сергіївна, кандидат економічних наук, доцент, доцент кафедри економічної теорії і економіки підприємства, Одеський державний аграрний університет

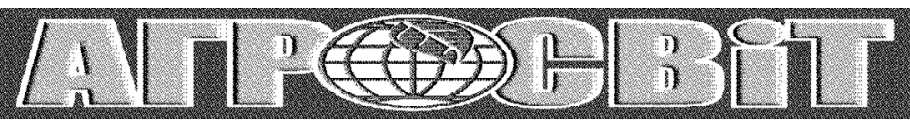

Журнал засновано у січні 2001 року. Виходить 2 рази на місяць.

№ 19 жовтень 2021 р.

Журнал включено до Переліку наукових фахових виАань України 3

ЕКОНОМІЧНИХ НАУК (Категорія «Б»).

Наказ Міністерства освіти і науки України

№ 975 від 11.07 .2019 p.

Спеціальності-051,071,072,073,075, 076, 292

ІНАЕКСАЦІЯ ВИААННЯ В НАУКОМЕТРИЧНИХ БАЗАХ:

- Index Copernicus (IC);

- SIS;

- Google Scholar.

Свідоцтво КВ № 23728-13568ПР від 27.12.2018 року ISSN 2306-6792

Передплатний індекс: 21847

Алреса редакціi:

04112, м. Київ, вул. Аорогожицька, 18, к. 29

Поштова аАреса:

04112, м. Київ, вул. Аорогожицька, 18, к. 29

Телефон: (044) 223-26-28, 537-14-33

Тел. факс: (044) 458-10-73

E-mail: economy_2008@ukr.net

www.agrosvit.info

Засновники:

Аніпровсъкий державний

аграрно-економічний університет,

TOB "АKC Ценmp"

Видавець:

TOB"АКС Центр"

Передрукування дозволяється лише за згодою редакції.

Відповідальність за добір і викладення фактів несуть автори. Редакція не завжди поділяє позицію авторів

публікацій.

За зміст та достовірність реклами несе відповідальність

рекламодавець.

Рекомендовано до друку Вченою Радою Аніпровського державного аграрно-економічного університету 07.10.21 p. Підписано до друку 07.10.21 p.

Формат 60х84 1/8, Ум. друк. арк. 8,7. Наклад - 1000 прим.

Папір крейдований, друк офсетний. Замовлення № 0710/1.

Віддруковано у ТОВ «АКС Центр» м. Київ, пров. Куренівський, 17

Тел. (044) 537-14-34

(C) АгроСвіт, 2021 


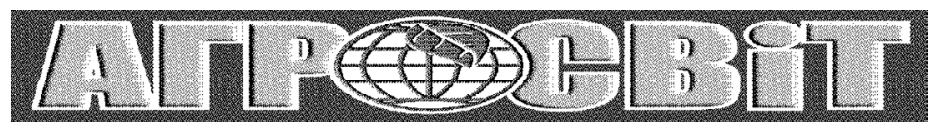

Журнал засновано у січні 2001 року. Виходить 2 рази на місяць.

\section{№ 19 жовтень 2021 р.}

\section{У HOMEPI:}

ВекличО.О.

Формалізація та параметризація оцінювання екосистемних послуг грунтів місцевого екосистемного активу 3

Ходаківська О. В., Орлова-КуриловаО. В., Кирилюк Е. М., Бучнєв М. М.

Моделювання системи управління інноваційним потенціалом та фінансової системи економіки: компенсаторні інструменти державного впливу в умовах глобалізації.....

Шевиук Н. А., Тульчинсъка С. О., Вовк О. А., Темченко О. А.

Успішний розвиток стартап-школи в системі інноваційного простору закладу вищої освіти

Голян В. А., Заставний Ю. Б., Миклуш Т. С.

Органічне сільськогосподарське виробництво в умовах децентралізації: фінансове

та інституціональне забезпечення

Токариук А. М.

Удосконалення організації переробки відходів на біогаз та тверде біопаливо на рівні громад в Україні 31

Удовенко I. О., Шемякін М. В., Кононенко С. І., Мельник М. В.

Історія землеустрою України: від стародавніх часів до сьогодення ..

Ходаківський В. М., Максимович Г. Ю., Садурсъка А. М., Чайківсъка Т. П.

Сучасні умови та альтернативи розвитку інвестиційного забезпечення сільськогосподарських підприємств Житомирської області

КватиркоО.М.

Забезпечення конкурентоспроможності лісового сектору на еколого-економічних засадах: принципи та особливості

\section{№ $19 / 2021$}

\section{CONTENTS:}

Veklych O.

FORMALIZATION AND PARAMETRIZATION OF EVALUATION OF ECOSYSTEM SERVICES OF SOILS

OF LOCAL ECOSYSTEM ASSET

Khodakivska O., Orlova-Kurilova O., Kyryliuk Ye., Buchniev M.

MODELING OF THE INNOVATION POTENTIAL MANAGEMENT SYSTEM

AND THE FINANCIAL SYSTEM OF THE ECONOMY: COMPENSATORY

TOOLS OF STATE INFLUENCE IN THE CONTEXT OF GLOBALIZATION

Shevchuk N., Tulchynska S., Vovk O., Temchenko O.

SUCCESSFUL DEVELOPMENT STARTUP SCHOOL IN THE INNOVATIVE SPACE

OF THE INSTITUTIONOF HIGHER EDUCATION

Golyan V., Zastavnyy Y., Myklush T.

ORGANIC AGRICULTURAL PRODUCTION IN THE CONTEXT OF DECENTRALIZATION:

FINANCIAL AND INSTITUTIONAL SUPPORT

Tokarchuk D.

IMPROVEMENT OF ORGANIZATION OF WASTE PROCESSING FOR BIOGAS

AND SOLID FUEL AT THE COMMUNITY LEVEL IN UKRAINE

Udovenko I., Shemyakin M., Kononenko S., Melnyk M.

HISTORY OF LAND MANAGEMENT IN UKRAINE: FROM ANCIENT TIMES TO THE PRESENT

Khodakyvskyy V., Maksimovich G., Sadurska L., Tchaikivska T.

MODERN CONDITIONS AND ALTERNATIVES FOR THE DEVELOPMENT OF INVESTMENT SUPPORT

OF AGRICULTURAL ENTERPRISES OF ZHYTOMYR REGION

Kvatyrko O.

ENSURING THE COMPETITIVENESS OF THE FOREST SECTOR BASED ON ECOLOGICAL 


\title{
О. О. Веклич,
}

А. е. н., професор, головний науковий співробітник відАілу екосистемного оцінювання природно-ресурсного потенціалу, Аержавна установа "Інститут економіки природокористування та сталого розвитку Національної академії наук України" ORCID ID: 0000-0003-4566-8701

\section{ФОРМААІЗАЦІЯ ТА ПАРАМЕТРИЗАЦІЯ ОЦІНЮВАННЯ ЕКОСИСТЕМНИХ ПОС АУГ ГРУНТІВ МІСЦВОГО ЕКОСИСТЕМНОГО АКТИВУ}

\author{
O. Veklych, \\ Doctor of Economic Sciences, Professor, Chief Scientist of the Department of Ecosystem Assessment \\ of Natural Resource Potential, Public Institution "Institute of Environmental Economics \\ and Sustainable Development of the National Academy of Sciences of Ukraine"
}

\section{FORMALIZATION AND PARAMETRIZATION OF EVALUATION OF ECOSYSTEM SERVICES OF SOILS OF LOCAL ECOSYSTEM ASSET}

\begin{abstract}
Розкрито економічний сенс понять екосистемних послуг і екосистемних активів. Репрезентована логічна послідовність дій щодо порядку оцінювання екосистемних послуг. Уперше у вітчизняній фаховій літературі проведено формалізацію та прикладну параметризацію доходного внеску двох видів екосистемних послуг - регулюючої послуги 3 утримання вуглецю в грунті, що надаються грунтами природного зростання сільськогосподарських культур та забезпечуючої послуги з постачання врожаю, що надаються грунтами земель сільськогосподарського призначення як просторовою зоною місцевого екосистемного активу, орієнтуючи за їх зразком на здійснення анахогічних обчислень по іншим територіально конкретизованим екосистемним активам. Завдяки проведеним розрахункам внеску цих Авох видів екосистемних послуг грунтів спростовано поширений у загальній свідомості стереотип начебто дарових природних благ. Наголошено, що вартість екосистемної послуги з постачання врожаю, що надається грунтами земель сільськогосподарського призначення місцевого екосистемного активу, може бути врахована при визначенні ї орієнтовної ціни, що є важливим з огляду на відкриття ринку землі в Україні.
\end{abstract}

The value of local ecosystems belonging to local communities, biodiversity, their components as natural factors of normal life and meeting the needs of households and the community itself is to obtain socially and economically stable various benefits from the supply of these natural assets ecosystem services, and thus the dependence of the capacity of the territorial community on access to ecosystem services and the volume of their provision by ecosystem assets is fixed. Valuing the benefits of ecosystem services produced by these assets is the most influential factor in raising awareness of members of local communities about the economic contribution of community-owned ecosystems, especially in the current environment where ecosystems and their services are traditionally assigned an implicit zero value. Hence, the need to monetize ecosystem services provided by ecosystem assets owned by a particular territorial community is obvious.

The solution of this problem will be facilitated by the representation of the estimated income contribution of specific ecosystem services produced by the ecosystem asset of a certain territorial community, due to scientifically substantiated formalization of such contribution with subsequent parameterization of its calculation. At the same time, there is a lack of assessment of the monetary value of the contribution of soil ecosystem services in domestic professional sources, due

* Статтю підготовлено за результатами дослідження в рамках прикладної НАР III-33-20 "Оцінювання екосистемних активів територіальних громад", що виконується в АУ "Інститут економіки природокористування та сталого розвитку НАН України". 
to significant methodological complexity and lack of widely available source statistics, although such ecosystem services are basic for households and the most consumed members of the grassroots community. Therefore, the presented results of the author's research contribute to the elimination of this scientific gap.

In particular, for the first time in the domestic professional literature the formalization and parameterization of the income contribution of two types of ecosystem services - soil quantity regulation service provided by soils of natural growth of crops, and crop provisioning service provided by agricultural land as local ecosystem asset, focusing on their model on the implementation of similar calculations for other territorially specified ecosystem assets. The calculations show impressive but significant figures of the contribution of two types of soil ecosystem services, convincingly refuting the common stereotype of seemingly gifted natural goods. At the same time, the cost of the ecosystem crop supply service provided by the soils of agricultural lands of the local ecosystem asset can be taken into account when determining their approximate price, which is important given the opening of the land market in Ukraine. Applied results with appropriate popularization can serve as a numerical basis not only for awareness of local communities of the value of natural resources consumed by them, which produced by their ecosystem assets, intensifying, in turn, environmental measures and environmental management, but also to make communities aware of the availability of strong ecosystem potential and the ecosystem services, which allow communities to receive additional income from other users / beneficiaries of these services.

Ключові слова: екосистемні послуги, екосистемні активи, математичні методи очінювання екосистемних послуг, параметризачіл доходного внеску екосистемних послуг, територіальні громади.

Keywords: ecosystem services, ecosystem assets, namenamuчнi methods of assessment of ecosystem services, parameterization of the income contribution of ecosystem services, territorial communities.

\section{ПОСТАНОВКА ПРОБЛЕМИ}

Численними зарубіжними дослідженнями переконливо доведена залежність спроможності народонаселення до існування завдяки отримуваним вигодам і доходам від екосистемних послуг і на глобальному, і національному (особливо в країнах з низьким і середнім рівнем доходів), і на регіональному / субрегіональному рівнях, і на рівні територіально локальному (громади). Згідно з метою та положеннями Закону України "Про Основні засади (стратегію) державної екологічної політики України на період до 2030 року" щодо всебічного упровадження екосистемного підходу в управлінську практику, очевидна нагальна потреба в формуванні інституціональних умов для імплементації екосистемного підходу в практику господарювання територіальних громад і проведення відповідної інформаційно-просвітницької роботи. Безумовно, що започаткуванню такої широкомасштабної та складної роботи має передувати наукове опрацювання й розробка концепту екосистемних послуг, що надасть змогу громадам не лише усвідомити цінність просторово належних їм екосистем і необхідність їх збереження та відтворення, а й надалі визначити додаткові/нові джерела надходжень до власних місцевих бюджетів.
Цінність належних територіальним громадам місцевих екосистем, біорізноманіття, їх компонентів як природних чинників нормального життєзабезпечення та задоволення потреб домогосподарств і самої громади полягає в отриманні соціальних і економічних стабільних різноманітних вигод від постачання цими природними активами екосистемних послуг, а відтак фіксується залежність спроможності територіальної громади від доступу до екосистемних послуг і обсягу їх надання екосистемними активами. Тому проведення вартісної оцінки вигод від продукованих цими активами екосистемних послуг виявляється найвпливовішим чинником підвищення обізнаності членів територіальних громад щодо економічного внеску належних громаді екосистем, особливо в нинішніх умовах, коли екосистемам і генерованим ними послугам традиційно присвоюється неявне значення нуля. Звідси очевидною $є$ необхідність здійснення монетаризації екосистемних послуг, що надаються екосистемними активами, якими володіє та чи інша територіальна громада.

Вирішенню цієї проблеми сприятиме репрезентація оціненного доходного внеску конкретних екосистемних послуг, що продукується екосистемним активом певної територіаль- 
ної громади, завдяки науково обгрунтованій формалізації такого внеску з наступною параметризацією його обчислення.

\section{АНАЛІЗ ПОПЕРЕДНІХ ДОСЛІДЖЕНЬ І ПУБЛІКАЦІЙ}

У фаховій зарубіжній та вітчизняній літературі існує чималий масив розробок щодо методів оцінювання екосистемних послуг за авторством J. Wang, F. Soulard, Zhiyun Ouyang, Changsu Song, Hua Zheng, S. Polasky, Yi Xiao, M. Ruckelshaus, Weihua Xu, C. Daily, A.B. Невєрова, А.А. Тишкова, О.Е. Медведєвої, А.В. Касимова, В.В. Юрак, Н.В. Аегтярь, І.П. Соловія, A.A. Загвойської, G. Sandoval, D. Barton та інших, в яких представлено оцінки економічної вартості екосистемних послуг, що продукуються екосистемами певної місцевості.

Водночас у вітчизняних фахових джерелах спостерігається відсутність оцінювання грошової вартості внеску екосистемних послуг грунтів, зважаючи на значну методичну складність і відсутність широко доступних вихідних статистичні даних для проведення такого оцінювання, хоча саме такі екосистемні послуги є базовими для функціонування домогосподарств і найбільш споживаними членами територіальної громади низового рівня сільської територіальної громади. Тому викладені результати проведеного авторського дослідження сприяють усуненню цієї наукової прогалини.

\section{МЕТА ДОСЛІДЖЕННЯ}

Метою дослідження є репрезентація логічної послідовності дій щодо порядку оцінювання екосистемних послуг і розкриття конкретних математичних підходів до вартісного оцінювання внеску двох видів екосистемних послуг грунтів з відповідними формулами обчислення, на основі яких можливо здійснити прикладний розрахунок цих внесків.

\section{ВИКЛАД ОСНОВНОГО МАТЕРІАЛУ ДОСЛІДЖЕННЯ}

За офіційним міжнародним усталеним визначенням, наведеним у документі ООН, ФАО, Світового банку "Система еколого-економічного обліку 2012 р. - облік екосистем. Остаточний варіант" ("The System of EnvironmentalEconomic Accounting 2012 - Ecosystem Accounting. Final Draft"), що був затверджений у березні 2021 року Статистичною комісією ООН як базовий і фінальний, екосистемні послуги "є внесками екосистем у вигоди, які використовуються в економічній та іншій людсь- кій діяльності" [1, с. 335]. Тобто внесками екосистемних послуг у загальний добробут є вигоди або доходи, які отримують споживачі цих послуг у вигляді сприятливого для життя та суспільного виробництва навколишнього природного середовища, наприклад, економічного прибутку від природогосподарської діяльності, якісних продуктів харчування, оздоровлення населення, культурологічного та естетичного задоволення, нових знань і іншого.

Отже, вихідним і провідним у визначенні екосистемних послуг є поняття саме їх економічного внеску в добробут місцевої спільноти, тобто продукування економічних вигід для споживачів функцій та послуг, що забезпечуються локальними екосистемами. Таке розуміння дає змогу не лише ідентифікувати спектр екосистемних послуг 3 позиції ї господарської доцільності, а й включити їх як товар в економічний обіг, а надалі - i в систему прийняття економічних рішень, починаючи 3 вихідного низового рівня суб'єктів природокористування - територіальних громад.

Продуцентами екосистемних послуг $€$ екосистемні активи, причому, як наголошено в міжнародному глосарії з еколого-економічного обліку, "екосистемні активи забезпечують екосистемні послуги або з одного екосистемного активу, або з кількох екосистемних активів, що діють спільно" [2]. Попередньо проведеним авторським дослідженням доведено $\mathrm{i}$ встановлено: екосистемні активи територіальних громад - це сукупність нагромаджених і функціонуючих природних активів, що надають екосистемні послуги та мають грошову вартість, створюючи матеріальну й нематеріальну вигоду територіальній громаді як суб'єкту природокористування внаслідок права власності на них протягом деякого періоду часу. Право власності територіальних громад на екосистемні активи як на об'єкти права комунальної власності реалізується їх присвоєнням, володінням, розпорядженням і використанням в сукупності чи в окремих часткових проявах цього права, а також згідно з положеннями вітчизняної правової бази щодо права власності на природні об'єкти. Таким чином, екосистемним активам територіальних громад притаманний сутнісний дуалізм, який полягає у тому, що ці активи одночасно є і природним, і специфічним економічним активом [3].

Спираючись на тематичні положення міжнародних документів з еколого-економічного обліку, виявлено, що процедурі вартісного оцінювання екосистемних активів територіальних громад має передувати процес поетапного 
обчислення біофізичної та економічної цінності екосистемних послуг шляхом застосування комплексу взаємообумовлених відповідних методів [4]. Аоведено, що вихідна дія щодо вимірювання екосистемних активів полягає насамперед у здійснені оцінки екосистемних послуг, які продукуються цими активами.

Виходячи 3 викладених цих документах відповідних положень і орієнтуючись на результати проведеного аналітичного огляду численних зарубіжних розробок з зазначеної проблематики, окреслимо алгоритм формалізації оцінювання екосистемних послуг, що продукуються екосистемним активом. Аля цього необхідно виконати таку поетапну послідовність дій. Зокрема:

1. Насамперед необхідно означити у вигляді формальної системи природно-фізичні прояви екосистемних активів як виду природних активів, відрізняючи їх від інших структурних складових екологічних активів і не допускаючи помилкового ототожнення їх сутнісних властивостей. Такі дії, своєю чергою, реалізуються: i) аналітичним зонуванням території, належній конкретній громаді, та ідентифікацією екосистем даної території; iі) ідентифікацією екосистемних послуг, що надаються визначеним екосистемним активом територіальної громади.

2. Важливо обрати базову групу екосистемних активів та їх відповідні основні біотичні компоненти з вибіркою цільового використання. Варто зазначити, що проведеним дослідженням обгрунтовано та розкрито базові групи екосистемних активів 3 притаманними їм основними біотичними компонентами $[4$, табл. 1]. Зокрема, в контексті нашого дослідження та 3 огляду на існуючі теоретичні здобутки щодо оцінювання екосистемних послуг грунтів місцевого екосистемного активу й прикладну можливість здійснення їх параметризації, обрано такі дві базові групи екосистемних активів: 1) органічний вуглець - iз таким притаманним йому біотичним компонентом як гумус, що утримується в грунтах для підвищення їх родючості; 2) грунти земель для природного зростання зернових, технічних і кормових культур (землі природного зростання сільськогосподарських культур). При цьому основними біотичними компонентами цієї базової групи екосистемного активу є рілля; полезахисні смуги на землях сільськогосподарського призначення; природні луки; сіножаті; пасовища (вигони, пасовищні угіддя), а також землі, зайняті полезахисними смугами на землях сільськогоспо- дарського призначення, та землі, вкриті чагарниковою рослинністю природного походження [4]. Аоречно нагадати, що площі земель багаторічних насаджень виключено із розрахунку загальної площі земель природного зростання сільськогосподарських культур екосистемного активу, оскільки багаторічні насадження як біологічно культивовані не входять до складу основних біотичних компонентів базових груп екосистемних активів згідно з міжнародною установчою класифікацією екологічних активів, і відносяться не до екосистемних активів, а до екологічних активів [5, с. 156].

3. Встановлюються конкретні числові значення (в натуральних показниках) біофізичних характеристик виділеної для дослідження просторової зони екосистемного активу конкретної територіальної громади, тобто обраних видів базових груп екосистемних активів та їх біотичних компонентів, екосистемні послуги яких надалі підлягатимуть монетарному оцінюванню; здійснюються необхідні розрахунки та узагальнення їх чисельних значень.

4. Виокремлюються ті екосистемні послуги, що продукуються відповідною просторовою зоною екосистемного активу, які надалі підлягатимуть монетарному оцінюванню. Аоречно наголосити на тому, що саме з огляду на існуючі методологічні, методичні та статистичні вихідні можливості здійснення прикладних розрахунків щодо економічної цінності екосистемних послуг, які надаються грунтами екосистемного активу, і було обрано, зокрема, два види екосистемних послуг: 1) регулюючої послуги 3 утримання вуглецю в грунті (soil quantity regulation service), яка надається грунтами земель природного зростання сільськогосподарських культур; 2) забезпечуючої послуги 3 постачання врожаю (crop provisioning service) $)^{1}$, яка надається грунтами земель сільськогосподарського призначення екосистемного активу.

5. 3дійснюється грошова оцінка доходного внеску обраних видів екосистемних послуг завдяки, по-перше, віднаходженню адекватних методів їх оцінки з відповідними формулами обчислення, i, по-друге, параметризації вихідних даних, потрібних для визначення їх чисельних значень. Аетальніше ідеться про таке.

Справді, опрацювання зарубіжної фахової літератури по проблематиці застосування математичних підходів і методів вартісного оцінювання екосистемних послуг дало змогу вибудувати логічну послідовність визначення

\footnotetext{
${ }^{1}$ Вказано офіційно прийняті англомовні назви досліджуваних екосистемних послуг грунтів.
} 
внесків обраних двох видів екосистемних послуг грунтів місцевого екосистемного активу, а саме: за першим дослідницьким кроком провести формалізацію розрахунку їх вартостей, а за другим кроком - безпосередню параметризацію їх внесків.

Тоді спочатку за першим кроком, керуючись існуючими в наукових джерелах методами оцінки екосистемних послуг грунтів сільськогосподарських угідь (наприклад, [6, с. 96; 7]), підсумкову вартість внеску регулюючӧ̈ екосистемної послуги грунту з утримання вуглецю нами запропоновано визначати за такою формулою:

$$
\mathrm{V}=\mathrm{P} * \mathrm{R}
$$

де $\mathrm{V}$ - вартість внеску регулюючої екосистемної послуги грунту 3 утримання вуглецю (value of soil quantity regulation service), євро/ долар США або грн;

P - ціна 1 тони вуглецю, що міститься в грунті (price of 1 ton of carbon contained in the soil), євро/долар США або грн;

$\mathrm{R}$ - запаси органічного вуглецю в грунтах природного зростання сільськогосподарських культур (reserves of organic carbon in the soils of natural growth of agricultural crops), тон.

Своєю чергою ціна 1 тони вуглецю, що міститься в грунті $(\mathrm{P})$, розрахована за таким рівнянням:

$$
\mathrm{P}=\mathrm{CD} * \mathrm{~A}
$$

де $\mathrm{CD}$ - депонування вуглекислого газу (carbon dioxide deposition) однією тоною вуглецю, що міститься в грунті, т;

A - середня ринкова ціна на викиди двоокису вуглецю (average market price for $\mathrm{CO}_{2}$ emissions), євро/долар США.

Запаси органічного вуглецю в грунтах природного зростання сільськогосподарських культур (R) розраховані за формулою:

$\mathrm{R}=\mathrm{H} * \mathrm{~L}_{\mathrm{i}}$

де $\mathrm{H}$ - запас гумусу (humus reserve) $)^{2}, \mathrm{~T} /$ га;

$\mathrm{L}$ - площа земель природного зростання сільськогосподарських культур (land area of natural growth of agricultural crops), га;

і - певний вид територіальної громади (села, селища або добровільного об'єднання відповідно до Закону України "Про місцеве самоврядування" та статті 140 Конституції України).

Аотримуючись наведеної формалізації розрахунку економічної цінності регулюючої послуги з утримання вуглецю в грунті, надалі можливо провести їі параметризацію, яка завжди конкретизована до певного, територіаль- но визначеного екосистемного активу. Прикладом цьому слугує послідовний розрахунок вартості регулюючої екосистемної послуги грунту з утримання органічного вуглецю землями територіальної громади с. Семенівка Благодатненської об'єднаної територіальної громади Первомайського району Миколаӥвської області.

Оже, шляхом послідовних авторських розрахунків відповідно до наведених формул здійснено вартісну оцінку внеску регулюючої екосистемної послуги грунту з утримання органічного вуглецю земель природного зростання сільськогосподарських культур екосистемного активу територіальної громади с. Семенівка, а саме: у 2020 році він становив 4 млрд 504 млн 283,6 тис. грн (у доларовому еквіваленті - 150 млн 343,2 тис. дол.). Перерахунок вартості внеску цієї послуги в гривнях за гектар і в доларах за гектар показав відповідно такі величини: 1 млрд 106 млн 458,9 тис. грн/га та 36 млн 931,1 тис. дол./га.

Надалі, додержуючись наведеній логічній послідовності виконання прикладних розрахунків вартісного оцінювання екосистемних послуг, також проведено монетарну оцінку забезпечуючої екосистемної послуги 3 постачання врожаю, що надається землями сільськогосподарського призначення цієї територіальної громади. Зокрема, скориставшись оцінкою грошових значень для кожної екосистемної послуги на біом, які здійснені групою провідних вчених світового рівня під керівництвом професора Р. Аегрюта і професора Р. Констанци [8, с. $256 ; 9$, с. 54] та застосувавши вибірковий метод і метод трансферу вартості, обчислено внесок цієї послуги в загальний дохід територіальної громади с. Семенівка. Аоречно нагадати, що метод трансферу вартості дає змогу визначити економічну цінність послуги, застосовуючи існуючі оцінки тієї чи другої екосистемної послуги інших територій, виконаних раніше в даній країні або за кордоном. Після отримання даних проводиться коригування оцінки в поточних чи постійних цінах і грошових одиницях.

Так, за отриманими розрахунками, вартість внеску забезпечуючої екосистемної послуги 3 постачання врожаю, що надається землями природного зростання сільськогосподарських культур села Семенівка, в 2020 році становила 41 млн 224 тис. 780 грн (в доларовому еквіваленті - 1 млн 375, 99 тис. дол.). Іі перерахунок у гривнях за гектар і в доларах за гектар пока-

\footnotetext{
2 Запаси гумусу - величина, яка характеризує вміст гумусу в генетичному горизонті або будь-якому шарі грунту в розрахунку на певну площу. URL: https://monographies.ru/en/book/section?id=16413\#
} 
зав відповідно такі величини: 11 млн 575, 4 тис. грн/га та 386,363 тис. дол./га.

Наразі маємо вихідні числові дані для здійснення грошової оцінки екосистемних послуг грунтів місцевого екосистемного активу територіальної громади с. Семенівка у 2020 році. Тоді загальний внесок означених двох послуг грунтів екосистемного активу територіальної громади с. Семенівка визначається сумою двох доданків - вартістю регулюючої послуги з утримання вуглецю в грунті та вартістю екосистемної забезпечуючої послуги з постачання врожаю, яка надана землями сільськогосподарського призначення, належними цій сільській територіальній громаді. За розрахунками, цей доходний внесок становив 4 млрд 545 млн 508,371 тис. грн; а в доларовому еквіваленті - 151 млн 719,238 тис. дол., або 1 млрд 118 млн 034,3 тис. грн/га та 37 млн 317,46 тис. дол./га.

Отже, як показують наведені приклади алгоритмізації розрахунку економічної цінності двох видів послуг грунтів місцевого екосистемного активу, для розрахунку кожного виду екосистемних послуг, що продукуються просторовими зонами і біотичними компонентами екосистемних активів, необхідно насамперед віднаходити і застосовувати специфічні математичні підходи та методи їх вартісного оцінювання, адекватні досліджуваним екосистемним послугам по черзі. А надалі вже встановлена та розкрита формалізація розрахунку економічної цінності кожної досліджуваної екосистемної послуги конкретизується її параметризацією відповідно до вихідних статистичних даних щодо функціонування визначеного місцевого екосистемного активу територіальної громади чи спільноти певного рівня.

\section{ВИСНОВКИ 3 ПРОВЕДЕНОГО ДОСЛІДЖЕННЯ}

Підсумовуючи результати дослідження, варто наголосити на такому.

По-перше, уперше у вітчизняній фаховій літературі проведена формалізація та параметризація доходного внеску двох видів екосистемних послуг - регулюючой послуги з утримання вуглецю в грунті, що надаються грунтами природного зростання сільськогосподарських культур, та забезпечуючої послуги з постачання врожаю, що надаються грунтами земель сільськогосподарського призначення як просторовою зоною місцевого екосистемного активу, орієнтуючи за їх зразком на здійснення аналогічних обчислень по іншим територіально конкретизованим екосистемним активам.
По-друге, проведені розрахунки показують вражаючі за величиною, але достовірні цифри внеску двох видів екосистемних послуг грунтів, доказово спростовуючи поширений у загальній свідомості стереотип начебто дарових природних благ.

По-третє, вартість екосистемної послуги 3 постачання врожаю, що надається грунтами земель сільськогосподарського призначення місцевого екосистемного активу, може бути врахована при визначенні їх орієнтовної ціни, що є важливим 3 огляду на відкриття ринку землі в Україні.

По-четверте, сумарні результати грошового обчислення економічної цінності/вартості доходного внеску розглянутих двох екосистемних послуг грунтів разом з ймовірними розрахунками внесків інших конкретних видів екосистемних послуг формують відправну числову платформу подальшого розрахунку загальної вартості екосистемного активу певної територіальної громади.

По-п'яте, одержані прикладні результати за відповідної популяризації можуть слугувати числовою базою не лише для усвідомлення територіальними громадами цінності споживаних ними природних благ, продукованих належними їм екосистемними активами, активізуючи своєю чергою проведення природоохоронних заходів і раціональне природокористування, а й для усвідомлення громадами наявності потужного екосистемного потенціалу, за продуковані яким екосистемні послуги допустимо отримувати додатковий дохід від інших користувачів/бенефіціарів цими послугами.

\section{$\Lambda$ ітература:}

1. System of Environmental-Economic Accounting- Ecosystem Accounting. Final Draft / United Nations, European Union, Food and Agriculture Organization of the United Nations, Organisation for Economic Cooperation and Development, World Bank Group. New York, Version 5, February 2021. - 350 p. URL: http:// unstats.un.org/unsd/statcom/52nd-session/ documents/BG-3f-SEEA-EA_Final_draft-E.pdf

2. What are ecosystem assets? System of Environmental-Economic Accounting. URL: https://seea.un.org/content/frequentlyaskedquestions\#Does $\% 20$ monetary $\% 20$ valuation $\% 20$ amount $\% 20$ to $\% 20$ putting $\% 20 \mathrm{a} \%$ 20 price $\% 20$ on \%20nature

3. Веклич О.О. Сутнісна характеристика екосистемних активів територіальних громад. О.О. Веклич // Ефективна економіка. 2020. № 5. URL: http://www.economy.nayka.com.ua/ 
?o $\mathrm{p}=1 \& \mathrm{z}=7888$ DOI: $10.32702 / 2307-2105$ 2020.5.17

4. Веклич О.О. Структурна характеристика комплексу ключових методів оцінювання екосистемних активів місцевих територіальних громад/ О.О. Веклич // Ефективна економіка. 2021. № 5. URL: http://www.economy.nayka.com.ua/?op $=1 \& z=8870$. DOI: $10.32702 / 2307$ 2105-2021.5.1

5. System of Environmental-Economic Accounting 2012 - Experimental Ecosystem Accounting / United Nations, European Union, Food and Agriculture Organization of the United Nations, Organisation for Economic Cooperation and Development, World Bank Group. - New York, 2014. 177 p. URL: https://unstats.un.org/ unsd/envaccounting/seeaRev/eea_final_en.pdf (дата звернення: 14.07.2021).

6. Артеменков А.И. Оценка стоимости земли в системе национальных счетов. Курс лекций / А.И. Артеменков, О.Е. Медведева, С.В. Соловьева. - M., 2015. - 111 с. URL: http:// anohraniteli.ru/upload/medvedevao.pdf

7. Стеценко А.В. Почвы. Запасы органического углерода в сельскохозяйственных почвах / А.В. Стеценко // Влияние глобального изменения кдимата и Киотского протокола на развитие защитного земледелия. Семинар. - М., 14 марта 2005 года. URL: http://rudocs.exdat.com/docs/index-220303.html

8. Costanza R. The Value of the World's Ecosystem Services and Natural Capital [Electronic resource] / R. Constanza, R. d'Arge, R. de Groot et al. // Nature. 1997. № 387 (6630). P. 253-260. URL: https://www.biodiversity.ru/ programs/ecoservices/library/common/doc/ Costanza_1997.pdf

9. de Groot R. Global estimates of the value of ecosystems and their services in monetary units / L.Brander, S. der Ploeg, R. Costanza et al. // Ecosystem Services. 2012. Vol. 1 (1). P. 50-61. URL: https://reader.elsevier.com/reader/sd/pii/ S2212041612000101? token $=6$ F11473827CD90603F816D24CC103645BB431D88A68336421CE3C7AA8BEBC978EEE807C3193384EF956617EA02D2EF 15 \& origin Region $=$ eu - west $-1 \&$ originCreation $=20210615174807$

\section{References:}

1. United Nations (2021), "System of Environmental-Economic Accounting- Ecosystem Accounting. Final Draft", Version 5 of February, available at: http://unstats.un.org/unsd/statcom/ 52 nd-session/documents/BG-3f-SEEAEA_Final_draft-E.pdf (Accessed 21 September 2021).
2. System of Environmental-Economic Accounting (2021), "What are ecosystem assets?", available at: https://seea.un.org/content/frequently-asked-questions\#Does $\% 20$ monetary\%20 valuation $\% 20$ a mount $\% 20$ to $\% 20$ putting $\%$ 20 a $\% 20$ price $\% 20$ on\%20nature (Accessed 21 September 2021).

3. Veklych, O.O. (2020), "Essential characteristic of ecosystem assets of territorial communities", Efektyvna ekonomika, [Online], vol. 5, available at: http://www.economy.nayka.com.ua/ ?op $=1 \& z=7888$ (Accessed 21 September 2021).

4. Veklych, O.O. (2021), "Structural characteristic of the complex of key methods of assessment of ecosystem assets of local territorial communities", Efektyrna ekonomika, [Online], vol. 5, available at: http://www.economy.nayka.com.ua/?op $=1 \& z=8870 \quad$ (Accessed 21 September 2021).

5. United Nations (2014), "System of Environmental-Economic Accounting 2012 - Experimental Ecosystem Accounting", available at: https:// unstats.un.org/unsd/ envaccounting/seeaRev/ eea_final_en.pdf (Accessed 21 September 2021).

6. Artemenkov, A.I. and Medvedeva, O.E. (2015), "Assessment of the value of land in the system of national accounts. Course of lectures", available at: http://anohraniteli.ru/upload/medvedevao.pdf (Accessed 21 September 2021).

7. Stetsenko A.V. (2005), "Soils. Stocks of organic carbon in agricultural soils", Vliyaniye globalnogo izmeneniya klimata i Kiotskogo protokola na razvitiye zashchitnogo zemledeliya. Seminar 14 marta [Impact of global climate change and the Kyoto Protocol on the development of protective agriculture. Seminar of March 14], Moscow, Russia, available at: http:// rudocs.exdat.com/docs/index-220303.html (Accessed 21 September 2021).

8. Costanza, R. and d'Arge, R. (1997), "The Value of the World's Ecosystem Services and Natural Capital", Nature, vol. 387 (6630), pp. 253-260, available at: https://www.biodiversity.ru/programs/ecoservices/library/common/doc/ Costanza_1997.pdf (Accessed 21 September 2021).

9. de Groot, R. and Brander, L. (2012), "Global estimates of the value of ecosystems and their services in monetary units", Ecosystem Services, vol. 1 (1), pp. 50-61, available at: https://reader.elsevier.com/ reader/sd/pii/S2212041612000101? token=6F11473827CD90603F816D24CC103645BB431D88A 68336421 CE3C 7 A A 8BEBC 978 EEE 807 C3193384EF956617EA02D2EF15\&originRegion=euwest-1\&originCreation=20210615174807 (Accessed 21 September 2021).

Стаття надійшла до редакиї 21.09.2021 p. 
УАK 330.341.2:338.242.2

О. В. Ходаківська,

А. е. н., професор, заступник директора ННЦ "Інститут аграрної економіки", м. Київ, Україна ORCID ID: 0000-0002-3421-8361

О. В. Орлова-Курилова,

А. е. н., Аоцент, завідувач кафедри менеджменту, права, статистики та економічного аналізу, Ауганський національний аграрний університет, м. Старобільськ, Україна

ORCID ID: 0000-0001-8382-8070

E. М. Кирилюк,

А. е. н., професор, завідувач кафедри економіки та міжнародних економічних відносин, Черкаський національний університет імені Богдана Хмельницького, м. Черкаси, Україна ORCID ID: 0000-0001-7097-444X

М. М. Бучнєв,

к. е. н., Аоцент, Аоцент кафеАри публічного управління, менеАжменту

та маркетингу, Східноукраїнський національний університет

імені Володимира Ааля, м. Сєвєродонецьк, Україна

ORCID ID: 0000-0002-7503-5705

DOI: $10.32702 / 2306-6792.2021 .19 .10$

\title{
МОАЕАЮВАННЯ СИСТЕМИ УПРАВАІННЯ ІННОВАЦІЙНИМ ПОТЕНЦІАЛОМ ТА ФІНАНСОВОЇ СИСТЕМИ ЕКОНОМІКИ: КОМПЕНСАТОРНІ ІНСТРУМЕНТИ АЕРЖАВНОГО ВПЛИВУ В УМОВАХ ГЛОБАЛІЗАЦІї
}

\author{
O. Khodakivska, \\ Doctor of Economic Sciences, Professor, Deputy Director, National Scientific Center \\ "Institute of Agrarian Economics", Kyev, Ukraine \\ O. Orlova-Kurilova, \\ Doctor of Economic Sciences, Associate Professor, Head of the Department of Management, Law, \\ Statistics and Economical Analysis, Luhansk National Agrarian University, Starobilsk, Ukraine \\ Ye. Kyryliuk, \\ Doctor of Economic Sciences, Professor, Head of the Department of Economics and International \\ Economic Relations, Bohdan Khmelnytsky Cherkasy National University, Cherkasy, Ukraine \\ M. Buchniev, \\ $\mathrm{PhD}$ in Economics, Associate Professor, Associate Professor of the Department of Public Administration, \\ Management and Marketing, Volodymyr Dahl East Ukrainian National University, Severodonetsk, Ukraine
}

MODELING OF THE INNOVATION POTENTIAL MANAGEMENT SYSTEM

AND THE FINANCIAL SYSTEM OF THE ECONOMY: COMPENSATORY

TOOLS OF STATE INFLUENCE IN THE CONTEXT OF GLOBALIZATION

У статті розглянуто компенсаторні інструменти державного впливу в умовах глобалізації в системі моделювання системи управління інноваційним потенціалом та фінансової системи економіки. Аоведено, що масштабність та складність реалізації процесу впровадження ідей в інноваційному підприємництві вказує на необхідність дотримання певних взаємозв'язаних етапів його реалізації, виконання яких сприяє якнайшвидшій комерціалізації нововведень на вітчизняному ринку. За такого процесу спостерігається тісний зв'язок між державною підтримкою та початковим 
плануванням бізнесу підприємця, який реалізує інноваційні ідеї. ВіАзначено, що інноваційний процес зАійснюється самостійно підприємцем за рахунок реалізації ініціативної, систематичної та високоризикованої діяльності, що переслідує мету освоєння та дифузії інновацій, а також досягнення ефективної комерціалізації продуктів інноваційного процесу при розповсюдженні на ринку нових товарів і послуг. Інноваційний процес відтворюється стейкхолдерами підприємництва 3 метою досягнення економічних і соціальних результатів та одержання прибутку при найменших витратах. Такий процес являє собою складну логічну Аіяльність, що включає сукупність послідовних циклів, які відтворюються в межах життєвого циклу підприємства або інноваційного проєкту. Реалізація інноваційного процесу на макрорівні передбачає аАаптивну комбінаторику чинників виробництва, комунікацію зі світовим суспільством, ринком споживачів і засвоєння надбань науково-технічного прогресу.

The article considers the compensatory tools of state influence in the context of globalization in the system of modeling the management system of innovation potential and the financial system of the economy. The innovative economy is the main source or key to the formation of the nation's competitive advantages, especially in an unfavorable external environment, where technological breakthroughs and trade liberalization must be under the close attention of state institutions. A particularly important issue of modernity in the process of state formation is to determine the determinants of state regulation in the period of exacerbation of political contradictions, the COVID-19 pandemic and the imbalance of the socio-economic system, which further determine the manifestations of crisis in the national economy. It is proved that the scale and complexity of the implementation of the process of implementing ideas in innovative entrepreneurship indicates the need to comply with certain interrelated stages of its implementation, the implementation of which facilitates the rapid commercialization of innovations in the domestic market. In this process, there is a close link between government support and the initial business planning of an entrepreneur who implements innovative ideas. It is noted that the innovation process is carried out independently by the entrepreneur through the implementation of initiative, systematic and high-risk activities that pursue the development and diffusion of innovations, as well as achieving effective commercialization of innovation products in the market of new goods and services. The innovation process is reproduced by business stakeholders in order to achieve economic and social results and make a profit at the lowest cost. This process is a complex logical activity that includes a set of consecutive cycles that are reproduced within the life cycle of the enterprise or innovation project. Implementation of the innovation process at the macro level involves adaptive combinatorics of factors of production, communication with the world community, the consumer market and the assimilation of scientific and technological progress.

Ключові слова: моделювання, система управління, інновачійний потениіал, фінансова система економіки, компенсаторні інструменти, державний вплив, глобалізачія.

Keywords: modeling, management system, innovation potential, financial system of economy, compensatory instruments, state influence, globalization.

\section{ПОСТАНОВКА ПРОБЛЕМИ У ЗАГАЛЬНОМУ ВИГЛЯДІ ТА ІІЇ ЗВ'ЯЗОК ІЗ ВАЖЛИВИМИ НАУКОВИМИ ЧИ ПРАКТИЧНИМИ ЗАВДАННЯМИ}

Формування державної інноваційної політики є ключовою рушійною силою економічного зросту та підвищення добробуту населення. Нововведення, винаходи, ноухау все більше визначають макроекономічні показники держави, забезпечують нові можливості диверсифікації виробництва та підвищують конкурентоспроможність промисловості. Інноваційна економіка є основним джерелом або ключем формування кон- курентних переваг нації, особливо в умовах несприятливого зовнішнього середовища, де технологічні прориви та лібералізація торгівлі повинні знаходитися під пильною увагою державних інституцій. Особливо важливим питанням сучасності в процесі державотворення $є$ визначення детермінантів державного регулювання в період загострення політичних протиріч, пандемії COVID-19 та порушенні рівноваги соціально-економічної системі, які ще більше обумовлюють прояви кризових явищ у національній економіці. Зазначені факти обумовлюють актуальність цього дослідження. 


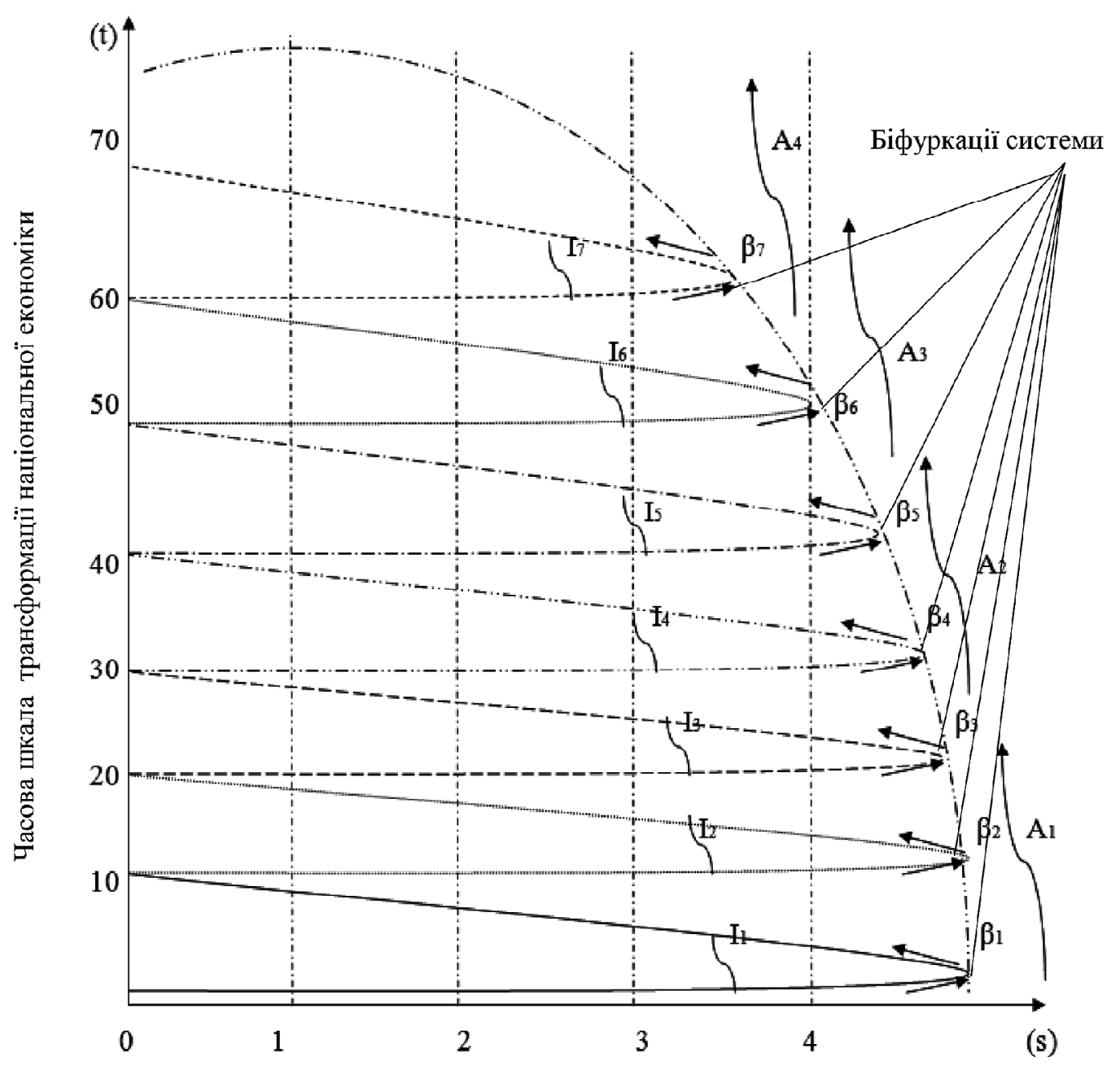

Ресурсний потенціал та інституціональне середовище

Рис. 1. Еволюційні цикли системи трансформації національної економіки

\section{АНАЛІЗ ОСТАННІХ ДОСЛІДЖЕНЬ І ПУБЛІКАЦІЙ, В ЯКИХ ЗАПОЧАТКОВАНО РОЗВ'ЯЗАННЯ ДАНОЇ ПРОБЛЕМИ І НА ЯКІ СПИРАЮТЬСЯ АВТОРИ, ВИДІЛЕННЯ НЕ ВИРІШЕНИХ РАНІШЕ ЧАСТИН ЗАГАЛЬНОЇ ПРОБЛЕМИ, КОТРИМ ПРИСВЯЧУЄТЬСЯ ОЗНАЧЕНА СТАТТЯ}

Проведення ООС на Сході України, експансія окремих східних та південних регіонів, неефективна державна регуляторна політика у сфері інноваційної діяльності призвели до скорочення умов екстенсивного економічного зростання, що терміново вимагає формування державної стратегії засобами повного оновлення та перезавантаження державної системи управління. Причому таке оновлення повинно грунтуватися з урахуванням того, що перспективний сталий економічний розвиток держави буде прямопропорційно залежати від наявного інноваційного потенціалу та оптимізації фінансової системи, а не від донорської фінансової підтримки $[2 ; 3 ; 10]$.
Аетермінанти державного регулювання інноваційним підприємництвом в умовах трансформації національної економіки особливо під час криз національної системи досліджували закордонні та вітчизняні вчені: П. Арукер, М. Крупка, М. Кондратьєва, А. Кляйнкнехта, О. Аапко, А. Аьвов, П. Майєрс, Х. Менш, К. Оппенлендер, О. Пригожин, П. Ромер, Б. Санто, В. Семиноженко, М. Скиба, Р. Солоу, Б. Твісс, М. Хаммер, П. Хоувітт, К. Фрімен, Й. Шумпетер, Юхновський, А. Яковлєв та інші $[1 ; 4 ; 5 ; 8$; 9]. Ми маємо значну дослідну теоретичну базу для формування детермінантів державної підтримки інноваційної діяльності та підвищення потенціалу підприємництва в період криз. Одночасно із зазначеним багато аспектів цієї проблематики потребують систематичного переусвідомлення та удосконалення з урахуванням сьогодення. Слід враховувати, що кризи в трансформаційній економіці України можна обернути, як основу майбутнього зростання та ключову можливість прогресивного розвитку 
вітчизняної промисловості, заснованої на інноваційних знаннях. Зазначене можливо досягти при вірно обраних детермінантах державного регулювання інноваційним підприємництвом [6; 7]. Таким чином, нова державна посткризова парадигма розвитку інноваційного підприємництва повинна формуватися з урахуванням інноваційних стимулів, компенсаторних стратегій особливо в часи хаотизації та реформування старих неефективних інститутів в національній економіці.

\section{META CTATTI}

Метою статті є дослідження компенсаторних інструментів державного впливу в умовах глобалізації у процесі моделювання системи управління інноваційним потенціалом та фінансової системи економіки.

\section{ВИКЛАД ОСНОВНОГО МАТЕРІАЛУ ДОСЛІДЖЕННЯ 3 ПОВНИМ ОБГРУНТУВАННЯМ ОТРИМАНИХ НАУКОВИХ РЕЗУЛЬТАТІВ}

Впровадження компенсаторних стратегій державою досить часто призводить до гістерезису та незадоволень суспільства від непопулярних адміністративних дій. Аосвід формування еволюційної парадигми інноваційного підприємництва доводить, що розвиток інноваційних зрушень за різних типів економічних систем держав відбувається нерівномірними циклами або спіралями розвитку. На вихідних спіралях спостерігається формування нових підприємств, які комунікують та конкурують між собою. Аеформації інституціонального середовища збуджують зовнішнє оточення підприємництва та сприяють наближенню підприємства до точки біфуркації, що підвищує турбулентність і організаційну дезорганізованість внутрішньої системи, призводить до накопичення імпліцитних проблем або протиріч, флуктуація яких наближує стейкхолдерів до системної кризи через низьку компенсаторіку супротиву. У такому контексті, інноваційну діяльність підприємництва слід розглядати під кутом просторових циклів еволюційної системи трансформаційної економіки, а планування такої діяльності повинне здійснюватися відповідно фазової моделі саморозвитку економіки, що трансформується (рис. 1).

Відповідно до рисунка 1 еволюція трансформаційної економіки відбувається в часовому асинхронному циклічному режимі. По осі абсцису зображена часова асинхронність трансформаційної економіки, що визначається ресурсним потенціалом та інституціональ- ним середовищем. По осіб ординат - відповідно ресурсний потенціал та інституціональне середовище національної економіки. $A 1 \ldots A 4$ - траєкторія зросту параметричної системи, що трансформує економіку та переводить її на новий стан розвитку.

При цьому $\beta 1 \ldots \beta 7$ - точки біфуркації, які обумовлюють трансформацію та визначають найоптимальніший період державного впливу на інноваційне підприємництво. Цикл $I 1 \ldots$ I7 вказує на оберненість системи економіки та перехід їі на новий стан розвитку. Розглянемо один 3 циклів системи трансформації національної економіки, з метою визначення найоптимальнішого часу впровадження державних заходів на інноваційне підприємництво. Так, перехід системи у точки біфуркації $\beta 1 .$. $\beta 7$ актуалізують необхідність якнайшвидшого активного державного впливу та регулювання інноваційного підприємництва. Точки біфуркації - це "революційні етапи", коли під час хаотичної або недосконалої національної системи підприємництва на руїнах неефективних інституцій постає потреба оновлення державної політики відповідно кон'юнктурних змін. Компенсаторними інструментами державного впливу на інноваційну діяльність є відокремлення в інституціональному середовищі окремих тенденцій: негентропії та ентропії; креативності та акцепторності; узгодженості та розбалансованості; випадковості та синхронності тощо. Вірне визначення зазначених тенденцій та оцінювання їх результатів у процесі державного регулювання потребує урахування наявних внутрішніх ресурсів і резервів перетворення державної політики для досягнення ефективного результату інноваційної діяльності у проміжку $I 1$.

Під час трансформації національної економіки та ї̈ наближення до точок біфуркації активно збільшується ентропія системи, що призводить до їі хаотичності або наближення до неврівноваженого стану, саме цей період $€$ найбільш сприятливим для флуктацій, тобто управлінських рішень зорієнтованих на кардинальне перетворення державної політики. Причому найліпший термін для реалізації державної політики є відрізок часу - I1, в якому знаходиться система. Чим більш наближена система до точки біфуркації тим ризиковані державні заходи впливу на підприємницьке середовище за рахунок мінімізації часу на їх реалізацію, що може при низькій швидкості їх впровадження призвести до повної деградації та руйнації системи підприємництва. Тобто оновлення системи підприємництва і перехід остан- 
ньої до нового циклу розвитку або самооновлення вимагає часу та швидкості реакції на експліцитні та імпліцитні проблеми розвитку інноваційної діяльності.

Складність державного регулювання і відповідно визначення його детермінантів, з огляду еволюційних циклів системи трансформації національної економіки позначається тим, що незадовільний результат від впровадження державних заходів при наближенні до точки біфуркації особливо підвищується, бо ентропія системи викликає ще більший супротив та опортуністичну поведінку стейкхолдерів підприємництва, внаслідок недостатності часу реагування на таку поведінку може призвести до низької ефективності державних регуляцій. Вчасний державний вплив у період $I 1$, дозволяє адаптуватися інституціональному середовищу до впроваджених державних заходів. $\Lambda$ ише окремі більш адаптовані підприємства виживають та, відповідно, допомагають стейкхолдерам пристосуватися до впроваджувальних змін, що мінімізує гістерезис.

\section{ВИСНОВКИ З ПРОВЕДЕНОГО ДОСЛІДЖЕННЯ I ПЕРСПЕКТИВИ ПОДАЛЬШИХ РОЗВІДОК У ЦЬОМУ НАПРЯМІ}

Акцентовано увагу на тому, що масштабність та складність реалізації процесу впровадження ідей в інноваційному підприємництві вказує на необхідність дотримання певних взаємозв'язаних етапів його реалізації, виконання яких сприяє якнайшвидшій комерціалізації нововведень на вітчизняному ринку. За такого процесу спостерігається тісний зв'язок між державною підтримкою та початковим плануванням бізнесу підприємця, який реалізує інноваційні ідеї. Відзначено, що інноваційний процес здійснюється самостійно підприємцем за рахунок реалізації ініціативної, систематичної та високоризикованої діяльності, що переслідує мету освоєння та дифузії інновацій, а також досягнення ефективної комерціалізації продуктів інноваційного процесу при розповсюдженні на ринку нових товарів і послуг. Інноваційний процес відтворюється стейкхолдерами підприємництва 3 метою досягнення економічних і соціальних результатів та одержання прибутку при найменших витратах. Такий процес являє собою складну логічну діяльність, що включає сукупність послідовних циклів, які відтворюються в межах життєвого циклу підприємства або інноваційного проєкту. Реалізація інноваційного процесу на мак- рорівні передбачає адаптивну комбінаторику чинників виробництва, комунікацію зі світовим суспільством, ринком споживачів і засвоєння надбань науково-технічного прогресу.

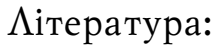

1. Гнатенко I.A. Визначення інновацій як інструментарію національного підприємництва. Науковий вісник Одеського національного університету імені I.I. Мечникова. Серія "Економіка". 2018. Т. 23. Вип. 5 (70). С. 38-42.

2. Гнатенко I. Вплив національного інноваційного підприємництва на сталий розвиток ринку праці. Вісник Херсонського державного університету. 2018. № 32. С. 69-72.

3. Гнатенко I.A. Методологічні основи інституціонального аналізу національної системи інноваційного підприємництва. Науковий журнал "Економічний вісник Запорізької державної інженерної академії". 2018. № 6 (18). C. $70-74$.

4. Гнатенко I.A. Методологічні аспекти розвитку інноваційного підприємництва: теорія та практика: монографія. Харків: СГ НТМ "Новий курс", 2019. 253 с.

5. Ходаківська О.В., Гнатенко I.А., Аяченко T.О., Сабій I.М. Моделі підприємництва в умовах інноваційної економіки та економіки знань: управління ресурсами та витратами. Інвестиції: практика та досвід. 2021. № 15. С. 5-11.

6. Brockova K., Rossokha V., Chaban V., ZosKior M., Hnatenko I., Rubezhanska V. Economic mechanism of optimizing the innovation investment program of the development of agroindustrial production. Management Theory and Studies for Rural Business and Infrastructure Development. 2021. Vol. 43. № 1. P. 129-135.

7. Hnatenko I., Kuksa I., Orlova-Kurilova O. Paragenesis of entrepreneurship and innovation as drivers of the future economy. Strategic Management: Global Trends and National Peculiarities. Collective monograph. Poland: Publishing House "Baltija Publishing", 2019. P. 48-61.

8. Hnatenko I., Kuksa I., Orlova-Kurilova O., Moisieieva N., Rubezhanska V. State regulation of innovative employment in the context of innovative entrepreneurship development. Management Theory and Studies for Rural Business and Infrastructure Development. 2019. № 41 (2). P. 228-236.

9. Lozhachevska O., Navrotska T., Melnyk O., Kapinus L., Zos-Kior M., Hnatenko I. Management of the logistical and marketing behavior of innovation clusters in territorial communities in the context of digitalization of society and the online market. Laplage In Review. 2021. № 7 (3). P. $315-323$. 
10. Zos-Kior M., Hnatenko I., Isai O., Shtuler I., Samborskyi O., Rubezhanska V. Management of Efficiency of the Energy and Resource Saving Innovative Projects at the Processing Enterprises. Management Theory and Studies for Rural Business and Infrastructure Development. 2020. Vol. 42. № 4. P. 504-515.

\section{References:}

1. Hnatenko, I. (2018), "Definition of innovations as tools of national entrepreneurship", Naukovyy visnyk Odeskoho natsionalnoho universytetu imeni I. I. Mechnykova. Seriya "Ekonomika", vol. 23, 5 (70), pp. 38-42.

2. Hnatenko, I. (2018), "The Impact of National Innovative Entrepreneurship on Sustainable Development of the Labor Market", Visnyk Khersonskoho derzhavnoho universytetu, vol. 32, pp. 69-72.

3. Hnatenko, I. (2018), "Methodological bases of institutional analysis of the national system of innovative entrepreneurship", Ekonomichnyj visnyk Zaporizjkoji derzhavnoji inzhenernoji akademiji, vol. 6 (18), pp. 70-74.

4. Hnatenko, I. (2019), Metodolohichni aspekty rozvytku innovatsijnoho pidpryiemnytstva: teoriia ta praktyka [Methodological aspects of innovative entrepreneurship development: theory and practice], New Course, Kharkiv, Ukraine.

5. Khodakivska, O.V. Hnatenko, I.A. Dyachenko, T.O. and Sabiy, I.M. (2021), "Models of entrepreneurship in terms of innovation economy and knowledge economy: resource and cost management", Investytsiyi: praktyka ta dosvid, vol. 15 , pp. 5-11.

6. Brockova, K. Rossokha, V. Chaban, V. ZosKior, M. Hnatenko, I. and Rubezhanska, V. (2021), "Economic mechanism of optimizing the innovation investment program of the development of agro-industrial production", Management Theory and Studies for Rural Business and Infrastructure Development, vol. 43.1, pp. 129-135.

7. Hnatenko, I. Kuksa, I. and Orlova-Kurilova, O. (2019), "Paragenesis of entrepreneurship and innovation as drivers of the future economy", Strategic Management: Global Trends and National Peculiarities. Collective monograph. Poland: Publishing House "Baltija Publishing", pp. 48-61.

8. Hnatenko, I. Kuksa, I. Orlova-Kurilova, O. Moisieieva, N. and Rubezhanska, V. (2019), "State regulation of innovative employment in the context of innovative entrepreneurship development", Management Theory and Studies for Rural Business and Infrastructure Development, vol. 41 (2), pp. 228-236.
9. Lozhachevska, O., Navrotska, T., Melnyk, O., Kapinus, L., Zos-Kior, M. and Hnatenko, I. (2021), "Management of the logistical and marketing behavior of innovation clusters in territorial communities in the context of digitalization of society and the online market", Laplage In Review, vol. 7 (3), pp. 315-323.

10. Zos-Kior, M. Hnatenko, I. Isai, O. Shtuler, I. Samborskyi, O. and Rubezhanska, V. (2020), "Management of Efficiency of the Energy and Resource Saving Innovative Projects at the Processing Enterprises", Management Theory and Studies for Rural Business and Infrastructure Development, vol. 42.4, pp. 504-515.

Стаття надійшла до редакиї 21.08.2021 p.

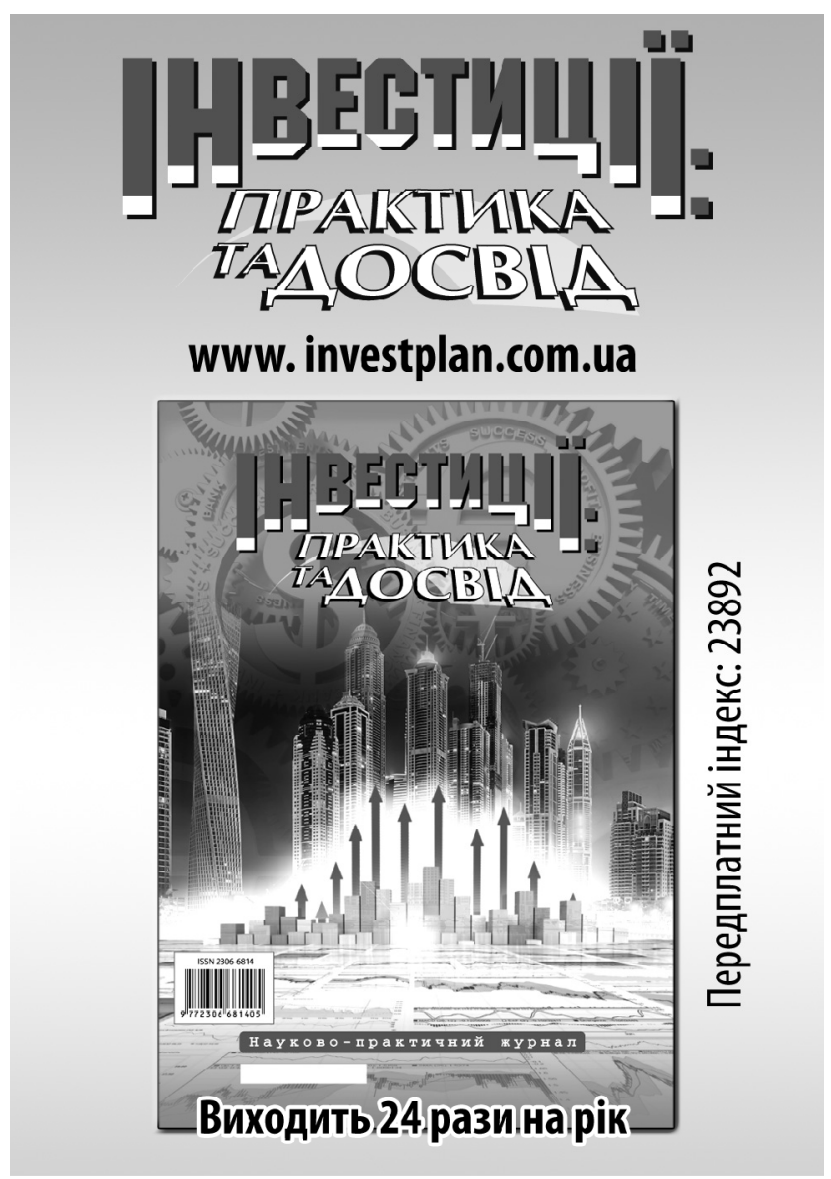

Журнал включено до переліку наукових фрахових видань України (Категорія «Б») 3

ЕКОНОМІЧНИХ НАУК та ДЕРЖАВНОГО УПРАВЛІННЯ

(Наказ Міністерства освіти і науки України № 886 від 02.07.2020)

Спеціальності - 051, 071, 072, 073, 075, 076, 281, 292 
УAK $330.332 ; 316.422 .4$

\title{
Н. А. Шевчук,
}

к. т. н., Аоцент, факультет менеАжменту та маркетингу, кафеАра економіки

і підприємництва, Націонадьний технічний університет України

"Київський політехнічний інститут імені Ігоря Сікорського"

ORCID ID: 0000-0003-0355-9793

C. О. Тульчинська,

А. е. н., професор, факультет менеджменту та маркетингу, кафедра економіки

і підприємництва, Національний технічний університет України

"Київський політехнічний інститут імені Ігоря Сікорського"

ORCID ID: 0000-0002-1409-3848

\section{О. А. Вовк,}

А. т. н., професор, Інститут енергозбереження та енергоменеджменту, кафедра геоінженерії, Національний технічний університет України

"Київський політехнічний інститут імені Ігоря Сікорського"

ORCID ID: 0000-0002-7531-9847

\section{O. А. Темченко,}

А. т. н., професор, Навчально-науковий економічний інститут, кафеАра економіки та підприємництва, Аержавний університет економіки і технологій

ORCID ID: 0000-0003-0020-2430

\section{УСПІШНИЙ РОЗВИТОК СТАРТАП-ШКОАИ В СИСТЕМІ ІННОВАЦІЙНОГО ПРОСТОРУ ЗАКАААУ ВИЩОЇ ОСВІТИ}

\author{
N. Shevchuk, \\ PhD in Technical Sciences, Associate Professor, National Technical University \\ of Ukraine "Igor Sikorsky Kyiv Polytechnic Institute", Ukraine \\ S. Tulchynska, \\ Doctor of Economic Sciences, Professor, National Technical University \\ of Ukraine "Igor Sikorsky Kyiv Polytechnic Institute \\ O. Vovk, \\ Doctor of Technical Sciences, Professor, National Technical University \\ of Ukraine "Igor Sikorsky Kyiv Polytechnic Institute" \\ O. Temchenko, \\ Doctor of Technical Sciences, Professor, Department of Economics and entrepreneurship, \\ Economics institute, State University of economics and technology, Kryvyi Rih, Ukraine
}

\section{SUCCESSFUL DEVELOPMENT STARTUP SCHOOL IN THE INNOVATIVE SPACE OF THE INSTITUTIONOF HIGHER EDUCATION}

У статті запропоновано розвиток стартап школи в системі інноваційного простору закладу вищої освіти як якісної інфраструктури з метою активізації наукових досліджень, підтримки розробок і впроваАження інновацій у виробництво. Наукова новизна полягає у налагодженні симбіозу освіта-наука-бізнес Аля комерціалізації інноваційних розробок, визначення доцільності фінансування стартап проєктів та розроблення критеріїв оцінки інноваційної привабливості і життєздатності проєктів з врахуванням внутрішнього і зовнішнього середовища на різних стадіях його розробки. Результати досліджень: модернізація освітнього процесу в Україні шляхом впровадження європейського 
досвіду комерціалізації інноваційних рішень; розвиток сучасного закладу вищої освіти підприємницького типу, поширення ефективних інструментів бізнес-навчання і підтримка технологічних проєктів на ранніх стадіях розробки; розробка системи критеріїв оцінки інноваційності та життєздатності проєктів.

On the article proposes the development of a startup school in the system of innovation space of a higher education institution as a quality infrastructure with the aim of intensifying research, supporting the development and introduction of innovations in production. The scientific novelty is in establishing symbiosis education-science-business for commercialize innovative developments, determining the advisability of financing startup projects and developing criteria for evaluating the innovation, attractiveness and viability of projects taking into account the internal and external environment at different stages of its development. Actual problem today is to create and support an academic environment which will become a common scientific space for applicants, inventors, scientists, who are studying, communicating, working and will embody their creative innovative ideas and models in life. The goal of research are providing increasing youth participation in advanced research, creation of innovative infrastructure, which will ensure the development and implementation of entrepreneurial directions and experimental operation, formation of innovative thinking, acquisition of skills and professional competences on commercialization of basic scientific and technical developments and will contribute to the successful development of the creative economy and the well-being of the country. Research results are modernization of Ukraine's education process through the introduction of European experience in commercialization of innovative solutions; development of a modern higher education institution of entrepreneurial type; disseminating effective business training tools and supporting technology projects in the early stages of development; development of a system of criteria for evaluating the innovativeness and viability of projects. Solving a problem increasing of a quality specialist training in modern universities necessitates economic justification proposed innovations future specialists in the technical profile and their implementation into the real sector of the country's economy for the purpose of ensuring production efficiency competitive goods and services on the national and world.

Ключові слова: стартап-школа, освіта, наука, бізнес, інновачї, інновачійні продукти. Key words: Startup-school, education, science, business, innovation, innovative products.

\section{ПОСТАНОВКА ПРОБЛЕМИ}

3 метою реалізації цілей сталого розвитку в Україні, запропоновано розвиток якісної, надійної та сталої інфраструктури вищого начального закладу для забезпечення активізації наукових досліджень, підтримки розробок і впровадження інновацій у сфері вітчизняних технологій. Актуальним завданням на сьогодні $є$ створення і підтримка академічного середовища, яке стане креативним простором для здобувачів освіти та науковців, які навчаючись, спілкуючись і працюючи будуть втілювати свої креативні інноваційні ідеї та винаходи у життя. Розв'язання проблеми підвищення ефективності професійної підготовки у технічних університетах зумовлює необхідність економічного обгрунтування пропонованих новацій майбутніми фахівцями технічного профілю та їх впровадження у реальний сектор економіки країни з метою забезпечення ефективності виробництва, конкурентоспроможних товарів і послуг на національному та світовому ринку, поступального розвитку національної еконо- міки та забезпечення її належного місця у світовій спільноті.

\section{АНАЛІЗ ОСТАННІХ ПУБЛІКАЦІЙ І ДОСЛІДЖЕНЬ}

Одним із основних чинників економічного зростання у більшості країн світу є впровадження інноваційних проєктів. Потреба в інноваційній діяльності пов'язана з відновленням країн після світової фінансової кризи, а сучасні технологічні трансформації ефективно будуть сприяти розвитку новітніх технологій та забезпечать реалізацію цілей сталого розвитку, включаючи регіональну та транскордонну інфраструктуру. Цю точку зору можна знайти у працях [1].

Стартап - це новітній проєкт, який розвивається в умовах невизначеності, забезпечує пошук економічно ефективних бізнес ідей і їх фінансування та спрямований на розроблення інноваційних товарів, послуг, технологій і виробництв. Вивчення та впровадження інноваційних проєктів на підприємстві 3 метою ство- 


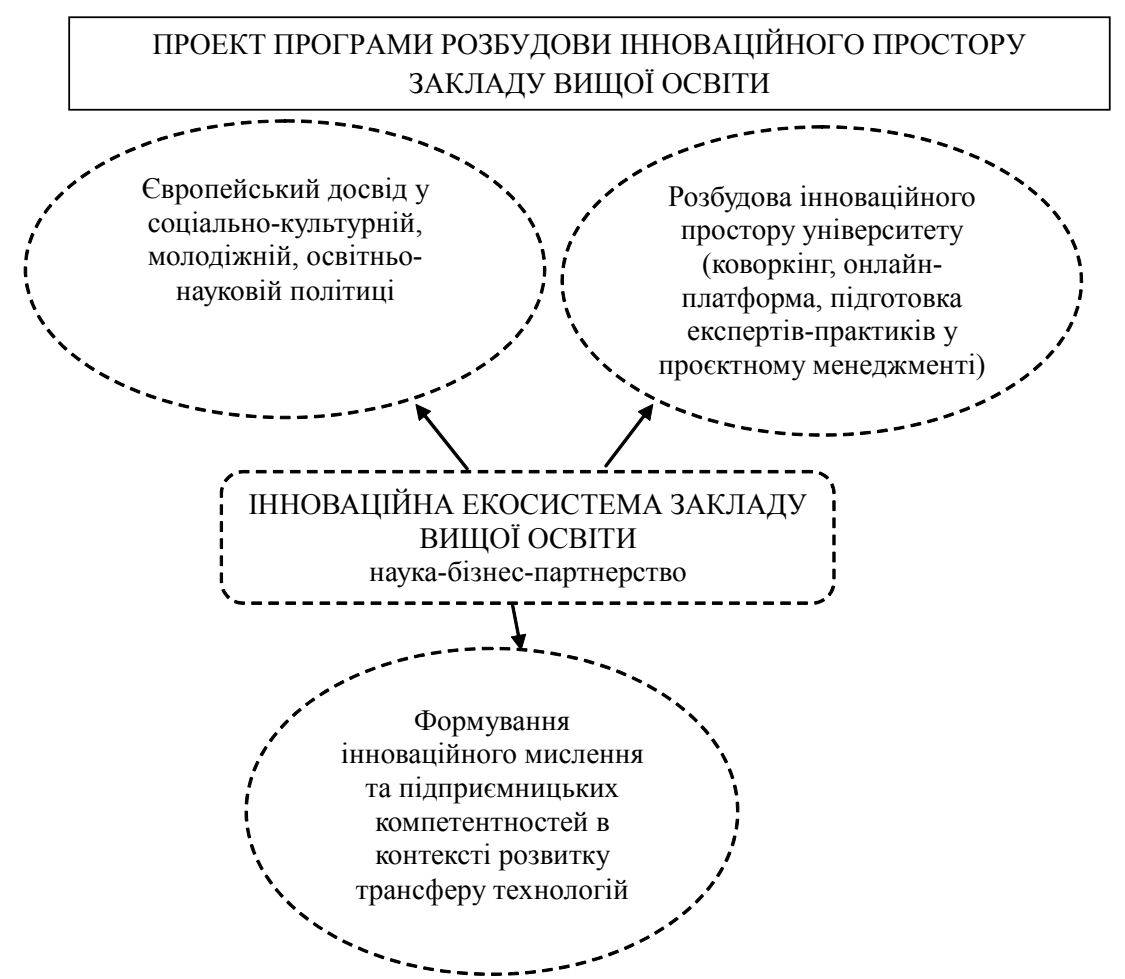

Рис. 1. Проєкт програми розбудови інноваційного простору закладу вищої освіти

рення успішного бізнесу детально було розкрито у працях [2-4].

\section{META CTATTI}

Метою дослідження є забезпечення збільшення участі молоді у наукових дослідженнях, створення інноваційної інфраструктури, яка забезпечить розвиток наукових досліджень та експериментальних розробок, формування інноваційного підприємницького мислення, набуття вмінь комерціалізації основних науково-технічних розробок, що буде сприяти розвитку креативної економіки і добробуту країни.

\section{ВИКЛАД ОСНОВНОГО МАТЕРІАЛУ}

В Україні існує понад 280 закладів вищої освіти III-IV рівнів акредитації. Випускники вишів в Україні часто не працюють за отриманою спеціальністю і не відповідають ринковим потребам. В університетах європейської спільноти формуються інкубатори академічного підприємництва, які стимулюють розвиток підприємництва та підтримують наукові дослідження та розробки. Наприклад, у сусідній Польщі діє понад 60 інкубаторів, які підтримують студентів та науковців, надають консультаційну, фінансову та юридичну допомогу для розвитку і впровадження інноваційних продуктів та технологій.
Розвиток інновацій та стартапів - це динамічний і прогресивний процес, який має відповідати ринковим потребам, об'єднувати інтереси всіх учасників екосистеми. Кожен учасник має певну мету. Інноватор або стартапер прагне реалізувати свою інноваційну ідею або проєкт, університети - отримати додаткові джерела фінансування для підтримки науковців та мати високі світові рейтинги, інвестори - вигідно вкласти кошти і отримувати прибутки, а держава мати інноваційні високоприбуткові підприємства, які будуть розвивати промисловість країни, успішно конкурувати у світовій спільноті та сплачувати податки [5]. Тому для функціонування екосистеми інноваційного підприємництва у закладах вищої освіти необхідно створити проєктні групи зацікавлених студентів, інноваторів, науковців для формування бізнес-ідеї та розробки інноваційного продукту, технології, які будуть співпрацювати з стейкхолдерами та менторами. Також необхідно створити державну підтримку інноваційних підприємств, продуктів і технологій. Необхідно розробити методологію оцінки ринкових перспектив комерціалізації інноваційних продуктів, розробити нормативноправову базу у сфері інвестування стартаппроєктів, забезпечити захист прав інтелектуальної власності, створити фонд страхування інвестицій, організовувати систему підготовки 


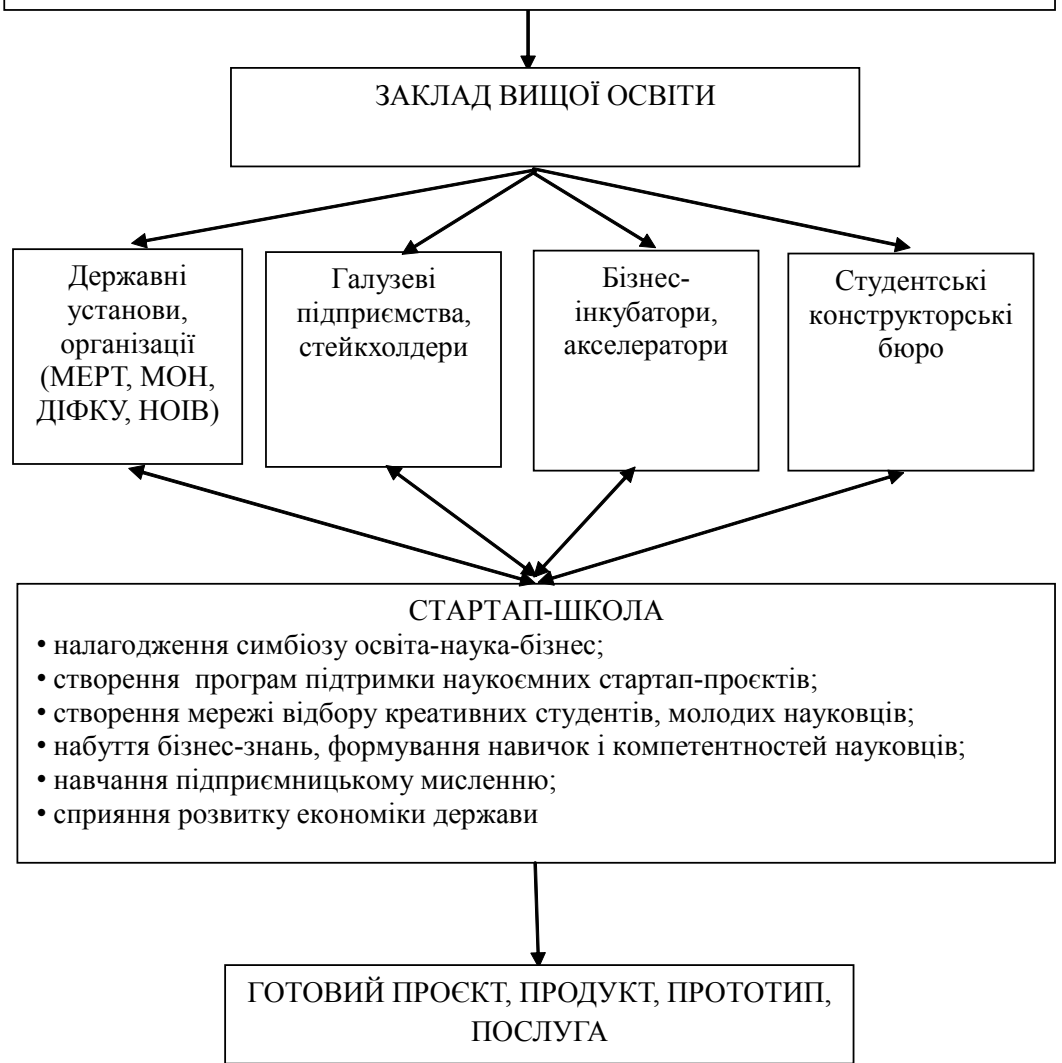

Рис. 2. Екосистема інноваційного простору закладу вищої освіти

управлінських працівників, які будуть супроводжувати розробку та комерціалізацію стартап-проєкту [6].

В Україні відсутня система фінансування фундаментальних наук і розробок, немає стимулів $\mathrm{i}$ системи відбору зацікавлених студентів, інноваторів, науковців і креативної молоді. Відсутня взаємодія між студентами, науковцями - науковими закладами - підприємствами, бізнесом урядом, державою. Практично не має платформ та комплексних програми, які створювали б сприятливі умови для підтримки інновацій [7].

Аля суттєвого покращення інноваційної діяльності пропонується розробити проєкт програми розбудови інноваційного простору закладу вищої освіти за схемою, наведеною на рисунку 1.

Основними цілями успішного розвитку стартап-школи в системі інноваційного простору закладу вищої освіти є:

- запуск у закладі вищої освіти нових ефективних інноваційних проєктів, які будуть сприяти розвитку інноваційного підприємництва у студентів, науковців, креативної молоді та формування шару інноваційно орієнтованих підприємців;
- засвоєння необхідних навичок для переходу від нечітких намірів до перспективних проєктів, забезпечення доступу до європейського досвіду та знань у галузі інновацій, просування та підтримки кращих команд та інноваційних продуктів;

- задоволення існуючих потреб регіону через розвиток підприємництва та необхідних інноваційних рішень;

- створення інструментів для підтримки та розвитку інноваційного підприємництва.

Аля реалізації комплексної системи інноваційного простору закладу вищої освіти необхідно:

- впровадити популяризацію досвіду сучасних європейських технологій підприємництва серед студентів, молодих вчених, активної молоді;

- створити якісну програму на основі європейського досвіду розробки інноваційних проєктів (з деталізацією) яка має бути гнучкою у залежності від потреб ринку, промисловості;

- укласти методику та документацію програми;

- формувати злагоджений колектив науковців, наставників, стейкхолдерів; 


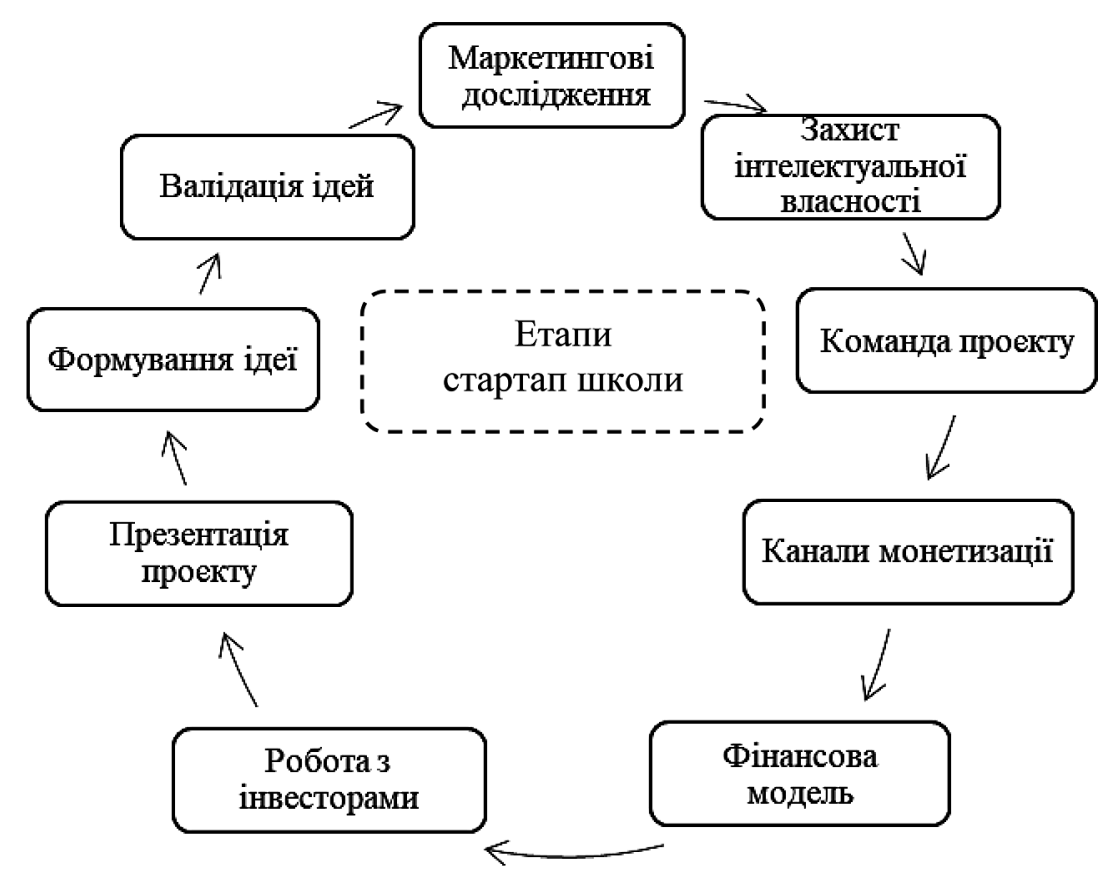

Рис. 3. Етапи розвитку стартап-школи

- створити експертну раду оцінювання стартап-проєктів;

- укласти бюджет програми;

- створити базу пошуку партнерів для підписання угод про співпрацю.

Підтримка та розвиток стартап-школи є комплексним процесом, реалізація якого включає:

- Аля забезпечення розвитку галузей промисловості необхідно збільшити фінансування державою наукових розробок у закладах вищої освіти;

- для сприяння розвитку інноваційного підприємництва розробку відповідних законопроєктів;

- підтримка соціальної спрямованості інноваційних проєктів;

- розвиток підприємницької культури;

- забезпечити захист прав інтелектуальної власності інноваційних стартап-проєктів;

- залучення міжнародних експертів та можливість участі у міжнародних програмах, конкурсах українських стартапів.

Проєкт програми розбудови інноваційного простору закладу вищої освіти передбачає наявність екосистеми (рис. 2).

Розвиток стартап-школи в системі інноваційного простору закладу вищої освіти - це сучасна освіта молоді для розвитку інновацій, яка має виступати каталізатором позитивних інноваційних змін в українському суспільстві, сприяючи розвитку підприємництва, підтри- муючи науково-технічні ідеї та стартові проєкти, спрямовані на вирішення проблем суспільства. Цільовою аудиторією мають бути студенти, молоді вчені, активна молодь, які зацікавленні в інноваційному підприємництві, які мають інноваційні ідеї, хочуть розширити свої проєкти та створити життєздатний бізнес у майбутньому. Перебуваючи в інноваційно-науковому середовищі, створюватимуться передумови для розвитку і реалізації нових ідей та розробки креативних бізнесмоделей. Створена екосистема технологічного підприємництва надасть безсумнівні переваги мережевої співпраці - неформальному об'єднанню студентів, обміну знаннями та досвідом, вільному доступу до широкого пулу експертів та менторів, трансферу техномогій та ідей, розвитку комерційних, та наукових ініціатив.

Екосистема інноваційного простору закладу вищої освіти включає: стартап-школу (рис. 3), бізнес інкубатор і раду інвесторів.

Стартап-школа - це простір, в якому за допомогою амбасадорів можна набути теоретичних знань та придбати практичні навички у галузі розробки інноваційних стартапів.

На етапі доведення актуальності ідеї та бачення вирішення конкретної проблеми необхідно створити центр неформальної освіти, який буде включати команду експертів, менторів, практиків (представників різних галузей) та підприємців. 
Бізнес-інкубатор - це ідеальний полігон для засновників стартапів, створений для отримання можливості налагодження бізнесу та підготовки до інвестиційних раундів, який сприяє створенню MVP (мінімально життєздатного продукту), опрацювання логічної моделі побудови клієнтоорієнтованного і інвестиційно-привабливого стартапу.

Рада інвесторів це майданчик, що створено 3 метою отримання додаткових коштів від мережі інвесторів. Вона включає наступні етапи:

- підготовка до інвестиційних раундів надання пораді найкращого представлення бізнес-ідеї;

- залучення інвестицій для реалізації інноваційних проєктів;

- запуску успішних стартап компаній.

Аля успішного впровадження стартап проєктів необхідно розробити критерії оцінки за показниками: значущість; інноваційність; життєздатність проєкту; потенціал команди.

По значущості запропоновано аналіз за такими ознаками:

- актуальність обраної проблеми, яка вирішується за допомогою стартапу, для цільової аудиторії (наведені вагомі аргументи для її підтвердження, наприклад статистичні дані, опитування тощо);

- соціальний вплив;

- масштаби соціального впливу (цінність і значимість внеску стартап-проєкту в життя суспільства в цілому);

- сформованість візії та місії.

Оцінка інноваційності рекомендується проводити за ознаками:

- новизна рішення і нестандартність підходу до вирішення проблеми;

- переваги рішення в порівнянні з вже існуючими (аналіз ринку, конкурентів);

- рівень, на якому знаходиться конкуренція на ринку цього продукту / технології.

Життєздатність проєкту та його реалізація може бути оцінена за допомогою:

- аналізу існуючої потреби в продукті / технології на ринку (спираючись на результати тестування);

- оцінки продукту, що отримано за допомогою спостережень, опитувань, роботи фокус-груп тощо;

- стадії проєкту, на якій знаходиться розробка продукту / технології;

— перспективності бізнес-моделі, що використовується у стартап-проєкті;

- реалізації організаційної моделі виробництва продукту/технології;
- рівня опрацювання маркетингової стратегії (продажі, аналіз ринку, пізнаванність бренду, ринковий попит, канали маркетингу та продажів);

- рівень опрацювання комунікаційної стратегіï;

- загального рівня ризиків запуску/ масштабування стартапу;

- наявності клієнтів (тих, хто готовий купувати продукт / технологію);

- рівня існуючих перешкод для входу на ринок;

- стадії знаходження фінансового планування (руху коштів);

- наявності фінансових ресурсів.

Потенціал команди може бути оцінений так:

- наявністю досвіду і навичок (професіоналізму) членів команди стартапу у заявленій сфері;

- ступінь мотивації і бажання у членів команди працювати над розвитком стартапу;

- вміння презентувати (продавати) позиціонувати свій продукт / технологію/ стартап.

Після детального опрацювання результатів оцінки стартап-проєктів приймається рішення життєздатності проєкту.

Необхідність оцінки фінансової вартості стартап-проєкту важлива для інвестора і стартапера. Важливо оцінити потенціал проєкту, вартість, ефективність та прибутковість. Принципи оцінки повинні включати фінансові показники на етапах реалізації проєкту та врахувати можливі ризики. Аоцільним є визначення середнього індексу вартості запуску стартаппроєкту:

$$
I_{\text {cost }}=\frac{C}{N}
$$

C - середня вартість запуску одного стартап-проєкту;

$\mathrm{N}$ - кількість поданих проєктів.

Визначення індексу конкурентоспроможності стартап проєкту з врахуванням критеріїв оцінки:

$$
\mathrm{K}=K_{s} \cdot K_{\text {in }} \cdot K_{v} \cdot K_{t}
$$

$\mathrm{K}_{\mathrm{s}}$ - коефіцієнт значущості стартап-проєкту;

$\mathrm{K}_{\text {in }}$ - коефіцієнт інноваційності стартаппроєкту;

$\mathrm{K}_{\mathrm{v}}$ - коефіцієнт життєздатності проєкту стартап-проєкту;

$\mathrm{K}_{\mathrm{t}}$ - коефіцієнт потенціалу команди стартап-проєкту.

Ефективність програми розбудови інноваційного простору закладу вищої освіти буде визначена кількістю підготовлених, впровад- 
жених, успішних і конкурентоспроможних стартап-проєктів, підготовлених на базі закладу вищӧ̈ освіти в симбіозі освіта-наукабізнес. Ці стартап-проєкти українських студентів та науковців будуть готові приймати участь у європейських та світових конкурсах, грантах і зможуть успішно конкурувати на світовому ринку, представляючи українську креативну молодь як потужний потенціал науки і бізнесу.

\section{ВИСНОВКИ}

Аля створення успішного розвитку стартапу-школи в системі інноваційного простору закладу вищої освіти необхідно законодавчі умови, які повинна забезпечити держава для успішної розбудови стартап-екосистеми України. Необхідно створити платформи для розробки та розвитку інноваційних стартаппроєктів. 3 метою реалізації стандартів забезпечення якості у Европейському просторі вищої освіти необхідно інтегрувати потенціал інноваційних проєктів для прискорення модернізації та трансформації промисловості та економіки України. Варто запровадити програму підтримки інноваційних проєктів урядом та державою, а також збільшити фінансування та інвестування в інтелектуальний потенціал технічних наук та студентів, молодих науковців, що здатні створювати та поширювати нові знання на наукові розробки для ефективного впровадження у промисловість країни та світу. Аля здійснення техніко-економічного обгрунтування, супроводу та реалізації інноваційних проєктів необхідно залучати та підвищувати кваліфікацію спеціалістів та експертів.

Запровадження вищевикладених пропозицій сприятиме розвитку взаємодї̈ та підтримки симбіозу освіта-наука-бізнес-влада, розвитку інноваційних технологій, захисту прав інтелектуальної власності, пошуку потенційних інвесторів та зацікавлених підприємств, залученню інвестицій в Україну, Евроінтеграцію та підвищення добробуту країни.

\section{$\Lambda$ iтература:}

1. Seyfang G., \& Smith A. Grassroots innovations for sustainable development: Towards a new research and policy agenda. Environmental Politics. 2007. 16 (4), pp. 584-603.

2. Ries, E. The lean startup: How today's entrepreneurs use continuous innovation to create radically successful businesses. New York: Crown Business. 2011.
3. Blank S., \& Dorf B. The startup owner's manual: The step-by-step guide for building a great company. Pescadero: K \& S Ranch. 2012.

4. Kohn A. The determinants of startup valuation in the venture capital context: a systematic review and avenues for futur. Doi: 10.1007/s11301017-0131-5.

5. Баб'ячок P.І. Основні тенденції розвитку стартапів в україні - проблеми, перешкоди і можливості. Київ, 2018.

6. Shevchuk N.A., Vapnichna V.V. Development and introduction startup project on the example of the geosynthetic module-formwork. Modern problems of economy and entrepreneurship. 2019. Issue 23, pp. 32-40.

7. Tulchynska S, Shevchuk N, Chorniy V, CHorniy B. Using a methodical approach to the evaluation of attractiveness investment resources for electricity distribution companies. Naukovyi visnyk NHU. 2018. № 2. Pp. 130-135.

\section{References:}

1. Seyfang, G. and Smith, A. (2007), "Grassroots innovations for sustainable development: Towards a new research and policy agenda", Environmental Politics, vol. 16 (4), pp. 584-603.

2. Ries, E. (2011), The lean startup. How today's entrepreneurs use continuous innovation to create radically successful businesses, Crown Business, New York, USA.

3. Blank, S. and Dorf, B. (2012), The startup owner's manual. The step-by-step guide for building a great company, K\& S Ranch, Pescadero, USA.

4. Kohn, A. (2018), "The determinants of startup valuation in the venture capital context: a systematic review and avenues for future research", Management Review Quarterly, vol. 68 (1), pp. 3-36.

5. Babyachok, R.I. (2018), Osnovni tendentsii rozvytku startapu v Ukraini - problemy, pereshkody ta mozhlyvosti [The main trends in the development of startups in Ukraine are problems, obstacles and opportunities], Kyiv, Ukraine.

6. Shevchuk, N.A. and Vapnichna, V.V. (2019), "Development and introduction startup project on the example of the geosynthetic module-formwork", Modern problems of economy and entrepreneurship, Issue 23, pp. 32-40.

7. Tulchynska, S. Shevchuk, N. Chorniy, V. and Chorniy, B. (2018), "Using a methodical approach to the evaluation of attractiveness investment resources for electricity distribution companies", Naukovyi visnyk NHU, vol. 2, pp. 130-135.

Стаття надійшла до редакиії 04.10.2021 p. 
УAK 338.439.02

\title{
В. А. Голян,
}

А. е. н., професор, Аиректор, Громадська організація

"Європейський аналітичний центр", м. Київ

ORCID ID: 0000-0002-2502-4573

Ю. Б. Заставний, Аоктор філософії в галузі економіки, м. Київ

ORCID ID: 0000-0002-9033-8018

T. С. Миклуш,

к. е. н., м. $\Lambda_{\mathrm{bB}}$ в

ORCID ID: 0000-0003-2522-1478

DOI: $10.32702 / 2306-6792.2021 .19 .23$

\section{ОРГАНІЧНЕ СІАЬСЬКОГОСПОААРСЬКЕ ВИРОБНИЦТВО В УМОВАХ АЕЦЕНТРААІЗАЦІЇ: ФІНАНСОВЕ ТА ІНСТИТУЦІОНААЬНЕ ЗАБЕЗПЕЧЕННЯ}

\author{
V. Golyan, \\ Doctor of Economic Sciences, Professor, Director, \\ Public Organization "European Analytical Centre", Kyiv \\ Y. Zastavnyy, \\ $\mathrm{PhD}$ in Economics, Kyiv \\ T. Myklush, \\ $\mathrm{PhD}$ in Economics, Lviv
}

\section{ORGANIC AGRICULTURAL PRODUCTION IN THE CONTEXT OF DECENTRALIZATION: FINANCIAL AND INSTITUTIONAL SUPPORT}

Виявлено, що внаслідок стагнаційних процесів у сільськогосподарському виробництві України на значній площі сільськогосподарських угідь роками не застосовувалися засоби захисту рослин та мінеральні добрива, що сформувало сприятливі передумови Аля розвитку органічного землеробства, органічного тваринництва та органічного кормовиробництва. Обгрунтовано, що розвиток органічного сільськогосподарського виробництва має базуватися переАусім на масштабній біологізації (внесення соломи та приорювання сидератів), вапнуванні та гіпсуванні грунтів, внесенні органічних добрив, безплужному обробітку грунту, мульчуванні грунтів, агролісомеліорації та інших меліоративних заходах. Встановлено, що значні резерви щодо нарощення потужностей органічного сільськогосподарського виробництва мають місце в зонах ризикового землеробства, зокрема на гірських територіях, у зонах осушення та зрошення. Аоведено, що вагомим каталізатором нарощення потужностей органічного землеробства та органічного тваринництва на меліорованих територіях є модернізація мережі гідротехнічних споруА, що Аасть можливість забезпечити необхідний Аля повноцінного сільськогосподарського виробництва водно-повітряний режим і відновити траАиційну сільськогосподарську спеціалізацію зони осушення та зони зрошення. Визначено, що поглиблення процесів децентралізації на сільських територіях створює додаткові переваги для розвитку органічного сільськогосподарського виробництва за умови диверсифікації джерел фінансового забезпечення: прямої та непрямої бюджетної підтримки і фінансово-кредитного стимулювання. Аослідження показали, що ефективною інституціональною формою активізації органічного сільськогосподарського виробництва в умовах децентралізації виступає кооперація фермерських та особистих селянських господарств, що дасть можливість підвищити рівень концентрації фінансових ресурсів, необхідних Аля розбудови матеріально-технічної бази зберігання та первинної переробки органічної рослинницької та тваринницької продукції. Обгрунтовано, що введення додаткових потужностей в органічний сегмент регіонального агропромислового комплексу дасть можливість повернути у сільськогосподарський оборот землі, які тривалий пер- 
іод не використовувалися, та зміцнити агроландшафти. Встановлено, що прискорення процесів розширеного відтворення потенціалу органічного сільськогосподарського виробництва в умовах децентралізації виступає вагомим чинником соціально-економічного піднесення сільських територій, оскільки сприяє створенню нових робочих місць та збільшенню надходжень до бюджету місцевого самоврядування, а також забезпечує позитивні зрушення в структурі місцевого господарського комплексу.

It is revealed that due to stagnant processes in agricultural production in Ukraine, plant protection products and mineral fertilizers have not been used on a significant area of agricultural land for years, which has formed favourable prerequisites for the development of organic farming, organic animal husbandry and organic feed production. It is proved that the development of organic agricultural production should be based primarily on large-scale biologization (straw application and green manure ploughing), liming and plastering of soils, application of organic fertilizers, plough-free tillage, soil mulching, agroforestry and other land reclamation measures. It is established that significant reserves for increasing the capacity of organic agricultural production occur in areas of risky agriculture, in particular in mountainous areas, in drainage and irrigation zones. It is proved that a significant catalyst for increasing the capacity of organic farming and organic animal husbandry in reclaimed areas is the modernization of the network of hydraulic structures, which will make it possible to provide the necessary water-air regime for full-fledged agricultural production and restore the traditional agricultural specialization of the drainage zone and irrigation zone. It is determined that the deepening of decentralization processes in rural areas creates additional advantages for the development of organic agricultural production, provided that the sources of financial support are diversified: direct and indirect budget support and financial and credit incentives. Studies have shown that an effective institutional form of activation of organic agricultural production in the context of decentralization is the cooperation of farmers and private farms. Such cooperation will make it possible to increase the level of concentration of financial resources necessary for the development of the material and technical base for storage and primary processing of organic crop and livestock products. It is proved that the introduction of additional capacities in the organic segment of the regional agro-industrial complex will make it possible to return to agricultural turnover land that has not been used for a long period, and strengthen agricultural landscapes. It is established that the acceleration of the processes of expanded reproduction of the potential of organic agricultural production in the context of decentralization is a significant factor in the social and economic recovery of rural areas. As it contributes to the creation of new jobs and increases revenues to the local government budget, as well as provides positive changes in the structure of the local economic complex.

Ключові слова: органічне сільськогосподарське виробниитво, безплужний обробіток грунmy, кооперачія, гідротехнічні споруди, місцеві бюджети, зайнятість.

Key words: organic agricultural production, plough-free tillage, cooperation, bydraulic structures, local budgets, employment.

\section{ПОСТАНОВКА ПРОБЛЕМИ У ЗАГАЛЬНОМУ ВИГЛЯДІ ТА ЇІ ЗВ'ЯЗОК ІЗ ВАЖЛИВИМИ НАУКОВИМИ ЧИ ПРАКТИЧНИМИ ЗАВДАННЯМИ}

Аецентралізація влади та реформа місцевого самоврядування призвели до зміцнення позицій об'єднаних територіальних громад, які отримали значні активи у володіння, користування та розпоряджання у зв'язку із дерегуляцією земельних відносин. Схвалення Закону України "Про внесення змін до деяких законодавчих актів України щодо вдосконалення системи управління та дерегуляції у сфері земельних відносин" [2] дало можливість передати у власність об'єднаних територіальних громад сільськогосподарські землі державної власності поза межами населених пунктів, що значно розширило просторовий базис для формування муніципального сегменту сільськогосподарського виробництва. Створення об'єднаних територіальних громад на основі поєднання потенціалу міських та сільських поселень створює сприятливі передумови для того, щоб запустити нові потужності в органічний сегмент місцевих агропромислових комплексів. Більше того, створення об'єднаних територіальних громад на основі міських та сільських населених пунктів формує додатковий попит на органічну сільськогосподарську продукцію і дає можливість місцевому самоврядуванню координувати діяльність суб'єктів органічного сільськогосподарського виробництва через передачу у користування сільськогосподарських земель та надання різного роду фінансових преференцій за рахунок коштів місцевих бюджетів. Тобто децентралізація створила додаткові можливості для прискореного розвитку органічного сільськогосподарського виробництва, що за умови формування відповідного інституціонального та фінансового забезпечення надасть нових імпульсів соціальноекономічному піднесенню об'єднаних територіальних громад. 


\section{АНАЛІЗ ОСТАННІХ ДОСЛІДЖЕНЬ І ПУБЛІКАЦІЙ}

$\mathrm{У}$ переважній більшості праць вітчизняних вчених органічне сільськогосподарське виробництво розглядається як вагомий фактор екологізації національного АПК та важлива детермінанта зміцнення стійкості агроландшафтів [5-7]. Водночас недостатньо опрацьованими залишаються підходи до формування сучасного фінансового інструментарію підтримки суб'єктів органічного сільськогосподарського виробництва, а також підходи, які стосуються удосконалення інституціонального забезпечення впровадження методів та технологій органічного землеробства, органічного тваринництва та органічного кормо виробництва [1; 3]. Виходячи $з$ передового іноземного досвіду стимулювання розвитку органічних сільськогосподарських виробництв, потребують удосконалення авторські підходи стосовно сертифікації суб'єктів агропромислового підприємництва, що застосовують органічні методи та технології, як необхідної інституціональної передумови ідентифікації виробників органічної рослинницької та тваринницької продукції для отримання фінансової допомоги зі сторони держави в рамках бюджетної підтримки національних товаровиробників [4]. Недостатньо ув'язаними $€$ пріоритети фінансового та інституціонального забезпечення органічного сільськогосподарського виробництва з тими перевагами та вигодами, які створює децентралізація для виробників органічної продукції.

\section{ЦІЛІ СТАТТІ}

Метою статті $є$ виокремлення пріоритетів фінансового та інституціонального забезпечення органічного сільськогосподарського виробництва в умовах децентралізації, виходячи з природно-ресурсних, виробничо-технічних та інфраструктурних передумов запровадження методів та технологій органічного землеробства, органічного тваринництва та органічного кормовиробництва.

\section{ВИКЛАД ОСНОВНОГО МАТЕРІАЛУ ДОСЛІДЖЕННЯ}

Національний аграрний сектор може отримати значні конкурентні переваги на світових ринках сільськогосподарської сировини та продовольства за умови суттєвого нарощення обсягів експорту органічної сільськогосподарської продукції. В останні роки для прискореного впровадження додаткових потужностей в органічний сегмент національного АПК створилися додаткові інституціональні переду- мови, що пов'язані з поглибленням реформи децентралізації, яка забезпечила сприятливі умови для нарощення потенціалу органічного сільськогосподарського виробництва. Отримавши значні площі сільськогосподарських земель поза межами населених пунктів територіальні громади мають змогу маневрувати просторовим базисом розвитку найбільш інвестиційно привабливих видів сільськогосподарського виробництва, якими виступають органічне землеробство, органічне тваринництво та органічне кормо виробництво. Водночас об'єАнані територіальні громади по-різному використовували і використовують потенціал росту органічного сільськогосподарського виробництва, що підтверджується значною територіальною неоднорідністю кількості суб'єктів агропромислового виробництва, які впроваджують методи та технології органічного сільськогосподарського виробництва.

Основною ресурсною умовою розвитку усіх підгалузей органічного сільськогосподарського виробництва виступає органічне землеробство, яке базується на застосуванні грунтозахисних технологій обробітку грунту, зокрема через використання технологій нульового обробітку грунту, застосування грунтозберігаючих технологій вирощування польових культур в умовах схилових земель України, використання технології смугової оранки. Застосування перерахованих технологій дозволяє сформувати сприятливі умови не лише для органічного землеробства, а й для підвищення ефективності використання матеріально-технічних ресурсів.

Зокрема, застосування технологій нульового обробітку грунту дає мождивість знизити витрати на вирощування сільськогосподарської продукції, забезпечити прискорене відновлення родючого шару грунту, запобігти ерозії грунтів, сприяти накопиченню вологи в грунті, що позитивним чином вплине на рівень конкурентоспроможності суб'єктів органічного аграрного виробництва та забезпечить зміцнення агроландшафтів.

Використання грунтозберігаючих технологій вирощування польових культур в умовах схилових земель України сприятиме поліпшенню агрофізичних властивостей грунтів, зменшенню щільності грунту; поліпшенню водопроникності, що дасть можливість зберегти високий рівень родючості грунтів як середньостроковій, так і в довгостроковій перспективі. Застосування технології смугової оранки сприятиме зменшенню кількості операцій та проходів техніки, проведенню в оптимальні строки основних весняно-польових робіт, покращенню 
Таблиця 1. Основні показники розвитку органічного землеробства в Україні станом на 31.12. 2019 року

\begin{tabular}{|c|c|c|c|}
\hline Регіони & $\begin{array}{c}\text { Загальна } \\
\text { кількість } \\
\text { операторів }\end{array}$ & $\begin{array}{c}\text { Загальна площа } \\
\text { сільськогосподарських } \\
\text { земель (органічних та } \\
\text { перехідного періоду), га }\end{array}$ & $\begin{array}{c}\text { Площа } \\
\text { сільськогосподарських } \\
\text { земель } 3 \text { органічним } \\
\text { статусом, га }\end{array}$ \\
\hline АР Крим & 0 & 0 & 0 \\
\hline Вінницька & 64 & 3559 & 2513 \\
\hline Волинська & 19 & 4564 & 4424 \\
\hline Дніпропетровська & 22 & 19111 & 15997 \\
\hline Донецька & 1 & 69 & 69 \\
\hline Житомирська & 34 & 37623 & 33141 \\
\hline Закарпатська & 18 & 1166 & 1080 \\
\hline Запорізька & 18 & 40433 & 16340 \\
\hline Івано-Франківська & 11 & 576 & 495 \\
\hline Київська & 83 & 60423 & 59505 \\
\hline Кіровоградська & 12 & 14478 & 14366 \\
\hline Луганська & 12 & 0 & 0 \\
\hline Львівська & 32 & 15104 & 14495 \\
\hline Миколаївська & 45 & 9430 & 9216 \\
\hline Одеська & 40 & 49608 & 41777 \\
\hline Полтавська & 27 & 25755 & 23564 \\
\hline Рівненська & 22 & 20403 & 9826 \\
\hline Сумська & 7 & 85 & 81 \\
\hline Тернопільська & 10 & 10278 & 10172 \\
\hline Харківська & 25 & 4578 & 3995 \\
\hline Херсонська & 54 & 84540 & 58506 \\
\hline Хмельницька & 25 & 12928 & 12235 \\
\hline Черкаська & 16 & 41428 & 41253 \\
\hline Чернівецька & 4 & 190 & 190 \\
\hline Чернігівська & 16 & 11650 & 11289 \\
\hline
\end{tabular}

Ажерело: за даними Міністерства розвитку економіки, торгівлі та сільського господарства України.

водно-фізичних властивостей грунтів. Тобто створення належних фінансових стимулів та інституціональних передумов для застосування грунтозахисних технологій обробітку грунту дасть змогу на порядок збільшити масштаби органічного землеробства та упередити екологодеструктвині процеси в аграрному природокористуванні.

Нині спостерігається значна територіальна неоднорідність як в розрізі кількості операторів, які реалізують проєкти органічного землеробства, так і в розрізі загальної площі органічних сільськогосподарських земель та сільськогосподарських земель перехідного періоду, зокрема площі сільськогосподарських земель 3 органічним статусом. Така ситуація пов'язана з тим, що в розрізі областей по-різному реалізуються пріоритети введення додаткових потужностей у сектор органічного землеробства, попри те, що фермерські і особисті селянські господарства завдяки застосуванню органічних технологій змогли б покращити своє фінансове становище. На 31.12.2019 року найбільша кількість операторів, які реалізують проєкти органічного землеробства, має місце у Вінницькій (64), Житомирській (34), Київській (83), Миколаївській (45), Одеській (40), Херсонській (54) областях (табл. 1).
Тобто найбільша кількість суб'єктів органічного землеробства спостерігається в регіоні (Київська область), центром котрого виступає найбільший мегаполіс країни. Наявність стабільного ринку збуту органічної сільськогосподарської продукціїє вагомою конкурентною перевагою для розвитку органічного сектора сільськогосподарського виробництва. Також в "столичному" регіоні має місце певний рівень розвитку матеріально-технічної бази та інфраструктурного забезпечення первинної переробки органічної сільськогосподарської продукції, що сприяє диверсифікації виробничої програми сертифікованих органічних господарств і створює передумови для розвитку органічного тваринництва. Також наближеність до адміністративного та ділового центру країни спрощує процес позитивного вирішення проблеми сертифікації органічної сільськогосподарської продукції та створює додаткові можливості для встановлення стабільних зв'язків 3 надійними контрагентами та спеціалізованими комерційними структурами.

Об'єктивною сприятливою передумовою Аля активізації органічного землеробства виступає рівень природної родючості грунтів, що виступає вагомим чинником зменшення капіталомісткості виробництва органічної сільсько- 
господарської сировини. Тому не дивно, що порівняно велика кількість операторів органічного землеробства спостерігається у Вінницькій області, яка характеризується одними 3 найбільш привабливих природно-ресурсних передумов для розвитку високопродуктивного сільськогосподарського виробництва загалом. Також у цьому регіоні високим рівнем розвитку відзначається індустрія переробно-харчових виробництв, що формує фінансові умови для додаткового інвестування проєктів налагодження виробництва органічної сільськогосподарської продукції. Тобто в цій області сформувався високий рівень концентрації капіталу у секторі переробно-харчових виробництв, що спрощує завдання залучення приватного інвестиційного капіталу в розбудову матеріально-технічної бази та інфраструктури виробництва, зберігання та первинної переробки органічної рослинницької та тваринницької продукції.

Порівняно велика кількість органічних сільськогосподарських виробництв в областях Українського Причорномор'я зумовлена наявністю значних площ зрошуваних сільськогосподарських угідь, які тривалий період не використовувалися у продуктивному сільськогосподарському обороті, а це найкращий полігон для застосування методів та технологій органічного землеробства. Також у цих областях створюються умови для відновлення традиційної спеціалізації, зокрема овочівництва, але вже на органічній основі. При цьому необхідною умовою запровадження додаткових потужностей в органічний сегмент овочівництва є модернізація та реконструкція мереж гідротехнічних споруд, що вимагає формування сучасних інституціональних форм аграрного бізнесу та Аиверсифікації джерел інвестиційного забезпечення. Приріст інвестицій в органічне овочівництво можливий на основі кооперації фермерських та соосбистих селянських господарств задля формування матеріальнотехнічної бази впровадження технологій грунтозахисного землеробства та розбудови індустрії зберігання органічної сільськогосподарської продукції.

Прикметною рисою збільшення потужностей в органічному землеробстві є факт того, що значний детермінуючий вплив на створення органічних сільськогосподарських виробництв в цьому регіоні також здійснює наявність великого мегаполіса м. Одеса. Близькість кордонів інших країн, наявність портів та розгалуженої мережі збуту продукції у місті-мільйоннику формують сприятливі інфраструктурні та фінансові передумови для зміцнення сектору органічного землеробства.

Однак ув'язувати прямий зв'язок масштабів поширення органічного землеробства 3 природною родючістю домінуючих грунтів в тому чи іншому регіоні не варто. Підтвердженням даного припущення є те, що порівняно високий рівень розвитку органічного землеробства спостерігається у Житомирській області, де розвиток органічного сектора сільськогосподарського виробництва набув значного розмаху у зв'язку з поєднанням потенціалу закладів вищої освіти та суб'єктів аграрного підприємництва. У цьому регіоні мають місце великі площі осушених сільськогосподарських угідь, які внаслідок руйнації внутрішньогосподарських мереж гідротехнічних споруд, були виведені з продуктивного відтворення і там не застосовувалися засоби захисту рослин від хвороб та шкідників, а також надмірні обсяги мінеральних добрив. На території осушувальних меліорацій склалися сприятливі умови не лише для розвитку органічного землеробства, а й для органічного тваринництва у зв'язку з наявністю значної площі самозаліснених сільськогосподарських угідь та пасовищ. Модернізація мереж гідротехнічних споруд осушувальних систем дасть можливість звести до мінімуму підтоплення сільськогосподарських угідь, що також $є$ фактором підвищення привабливості розвитку органічного сільськогосподарського виробництва на територіях, які роками були поза продуктивним сільськогосподарським оборотом.

Водночас прямої кореляції між кількістю операторів органічного землеробства та загальною площею органічних сільськогосподарських земель і сільськогосподарських земель перехідного періоду у більшості адміністративних областей не спостерігається. Значні площі органічних сільськогосподарських земель і сільськогосподарських земель перехідного періоду у Запорізькій та Черкаській областях при відносно невеликій кількості органічних виробництв свідчить про великотоварну спрямованість даного сектора сільськогосподарського виробництва в цьому регіоні. У Миколаївській області спостерігається один 3 найвищих показників активності в секторі органічних сільськогосподарських виробництв і відносно невисока площа органічних сільськогосподарських земель та сільськогосподарських земель перехідного періоду, що свідчить про домінування малих форм аграрного підприємництва в органічному землеробстві. Тому розроблення регіональних та місцевих програм підтримки органічного сільськогосподарського виробництва має стати важливим 


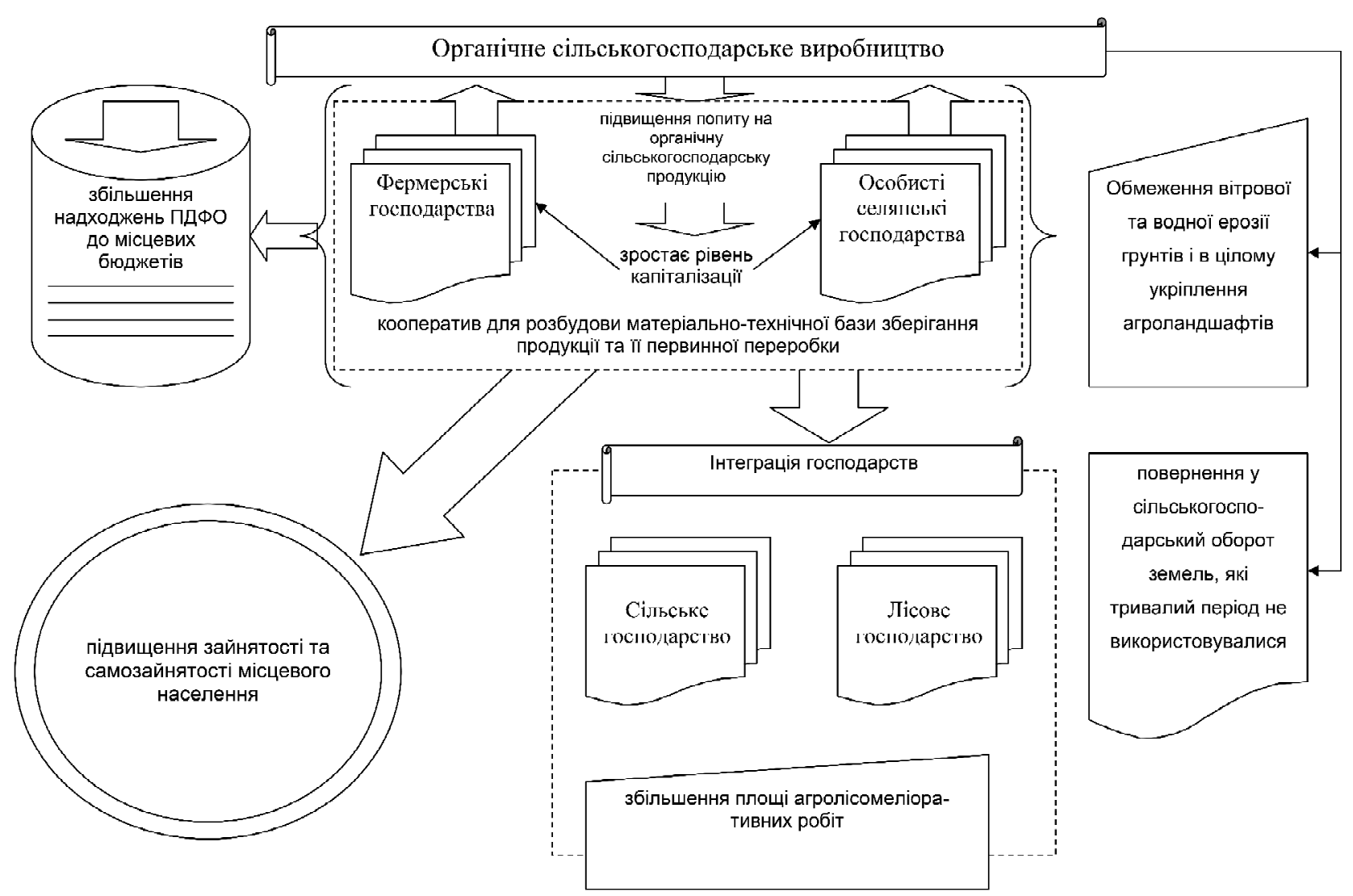

\section{Рис. 1. Органічне сільськогосподарське виробництво в системі соціально-економічного розвитку сільських територій}

пріоритетом місцевого самоврядування, зокрема рад та виконкомів новостворених об'єднаних територіальних громад.

Перспективними територіями для запровадження методів і технологій органічного сільськогосподарського виробництва виступають гірські території, в тому числі для розвитку органічного тваринництва. Явним є відставання Івано-Франківської області від більшості адміністративних областей України як стосовно кількості органічних сільськогосподарських виробництв, так і стосовно площі сільськогосподарських угідь, де здійснюється органічне землеробство. Це зумовлено як дефіцитом орних земель у гірській місцевості, так і відсутністю мотивації у сектора фермерських та особистих селянських господарств впроваджувати методи та технології органічного землеробства. Виходячи з того, що в цьому регіоні $є$ надзвичайно сприятливі передумови для розвитку зеленого та сільського туризму, органічне землеробство ще більше зміцнило б даний сегмент сільської економіки. Значною мірою це стосується і Чернівецької області. 3 огляду на сказане, важливого значення набуває розроблення загальнонаціональної програми підтримки органічного сільськогосподарського виробництва на гірських територіях.

Важливою інституціональною передумовою зміцнення позицій органічного сектора національного АПК є імплементація у практику регуляторного впливу на суб'єктів аграрного та агропромислового підприємництва інституту сертифікації органічного сільськогосподарського виробництва. Схвалення в останні роки нормативно-правових актів, які регламентують сертифікацію органічного сільськогосподарського виробництва, дало можливість сформувати комплекс інститутів-правил та інститутів-організацій такої сертифікації і наблизити тим самим даний сегмент національного АПК до технічних регламентів та стандартів Європейського Союзу.

В умовах поглиблення процесів децентралізації об'єднані територіальні громади отримали додаткові можливості для введення додаткових потужностей в органічне сільськогосподарське виробництво і мають забезпечити всі необхідні передумови, щоб органічний сектор місцевого АПК став одним з основних каталізаторів соціально-економічного піднесення, в першу чергу сільських територій. 
Аослідження показали, що органічне сільськогосподарське виробництво здатне забезпечувати прийнятний рівень капіталізації малих і середніх сільськогосподарських товаровиробників, навіть незважаючи на порівняно невеликі масиви сільськогосподарських угідь. Фактично органічне сільськогосподарське виробництво - це основна конкурентна перевага фермерських та особистих селянських господарств над великими суб'єктами аграрного бізнесу. Ця теза має бути закладена в систему фінансової підтримки органами місцевого самоврядування суб'єктів органічного сільськогосподарського виробництва. Виходячи 3 низького рівня фінансової самодостатності особистих селянських господарств, вони самотужки не можуть забезпечити необхідний рівень товарності органічної сільськогосподарської продукції. Тому необхідною умовою підвищення ефективності ведення органічного сільськогосподарського виробництва є формування обслуговуючих та збутових кооперативів для розбудови матеріально-технічної бази зберігання продукції та її первинної переробки (рис. 1). Саме кооперація є необхідною інституціональною передумовою для концентрації необхідних фінансових ресурсів для формування матеріально-технічної бази органічного сільськогосподарського виробництва.

Практика господарювання доводить, що впровадження додаткових потужностей органічного сільськогосподарського виробництва в секторі фермерських та особистих селянських господарств створює передумови для структурної перебудови сільської економіки, особливо в зоні ризикового землеробства. Особливо великий потенціал органічне сільськогосподарське виробництво має у фермерських та особистих селянських господарств, ареал діяльності котрих наближений до міських агломерацій, оскільки має місце надійний ринок для збуту готової продукції, як продукції рослинництва, так і проАукції тваринництва. Аля органів місцевого самоврядування - це вагомий аргумент для того, щоб формувати в структурі місцевих бюджетів спеціальні фінансові фонди щодо підтримки виробників органічної сільськогосподарської продукції, особливо фермерських та особистих селянських господарств.

Нарощення потужностей в органічному сільськогосподарському виробництві також має важливе значення для наповнення бюджетів місцевого самоврядування, що для депресивних сільських територій $є$ основною детермінантою соціально-економічного піднесення. Крім фіскального та бюджетного зна- чення для розвитку сільських поселень, органічне сільськогосподарське виробництво здійснює вагомий вплив на покращення екологічної ситуації та для збалансування процесів аграрного природокористування. Застосування грунтозахисних систем землеробства дозволяє обмежувати вітрову та водну ерозію грунтів, що загалом сприяє укріплення агроландшафтів та упереджує численні природоруйнівні процеси.

Тобто створюючи сприятливе інституціональне підгрунтя та формуючи фонди фінансової підтримки виробників органічної продукції, органи місцевого самоврядування тим самим вирішують екологічні проблеми підзвітних територій. Більше того, необхідно формувати фінансовий інструментарій для створення природно-ресурсних та виробничо-технічних передумов переходу суб'єктів аграрного підприємництва на модель органічного сільськогосподарського виробництва шляхом фінансового стимулювання впровадження технологій біологізації землеробства, вапнування та гіпсування грунтів, внесення органічних добрив, безплужного обробітку грунту, мульчування грунтів, агролісомеліорації та здійснення інших меліоративних заходів.

Максимальне використання резервів нарощення потенціалу органічного сільськогосподарського виробництва залежить від комплексності його ведення, тобто поєднання органічного землеробства та органічного тваринництва. Більше того, в разі комплексного розвитку органічного сільськогосподарського виробництва, тобто розвитку як органічного землеробства, так і органічного тваринництва, досягається зменшення рівня розораності сільськогосподарських угідь, що в нинішніх умовах галузевих перегинів (гіпертрофований розвиток експортоорієнтованих видів рослинництва) має вирішальне значення для забезпечення екологічної стійкості біогеоценозів. Органи місцевого самоврядування мають виходити 3 того, що збільшення потужностей стосовно запровадження грунтозахисних систем землеробства дасть можливість зміцнювати стійкість агроланшафтів і тим самим забезпечувати природно-ресурсну основу для поступального збільшення обсягів виробництва якісної сільськогосподарської продукції як у середньостроковій, так і в довгостроковій перспективі.

\section{ВИСНОВКИ I ПЕРСПЕКТИВИ ПОДАЛЬШИХ РОЗВІДОК}

Органічне сільськогосподарське виробництво виступає одним з найбільш перспективних 
сегментів національного АПК, а для об'єднаних територіальних громад воно може виступити одним з основних чинників соціально-економічного піднесення передусім сільських населених пунктів. Воно охоплює органічне землеробство, органічне тваринництво та органічне кормовиробництво. Основними природноресурсними та виробничо-технічними передумовами переходу на модель органічного сільськогосподарського виробництва виступають: біологізація землеробства, вапнування та гіпсування грунтів, внесення органічних добрив, безплужний обробіток грунту, мульчування грунтів, агролісомеліорація та інші меліоративні заходи. Створення такого роду передумов потребує фінансової підтримки як зі сторони держави, так і зі сторони органів місцевого самоврядування.

Аослідження показали, що органічне сільськогосподарське виробництво $€$ пріоритетним видом діяльності для сектору фермерських та особистих селянських господарств, які на основі кооперації здатні формувати фінансову основу для розбудови матеріально-технічної бази зберігання та переробки органічної сільськогосподарської продукції. Розвиток органічного сільськогосподарського виробництва $є$ вагомим чинником підвищення зайнятості та самозайнятості місцевого населення, обмеження вітрової та водної ерозії грунтів, укріплення агроландшафтів, повернення у продуктивний сільськогосподарський оборот земель, які тривалий період не використовувалися. Саме такі переваги та вигоди від нарощення потужностей органічного сільськогосподарського виробництва мають стимулювати органи місцевого самоврядування формувати в структурі місцевих бюджетів фінансові фонди підтримки виробників органічної сільськогосподарської продукції.

Органи місцевого самоврядування, отримавши у володіння та користування сільськогосподарські землі державної власності поза межами населених пунктів, значно збільшили свої можливості в частині нарощення потенціалу органічного сільськогосподарського виробництва і мають використати всі можливості для забезпечення необхідної інституціональної та фінансової підтримки виробників органічної сільськогосподарської продукції.

\section{$\Lambda$ ітература:}

1. Грановська В.Г. Механізми стимулювання розвитку підприємств органічного сектору: адаптація світового досвіду. Економіка і суспільство. 2017. № 9. С. 384-390.
2. Закон України "Про внесення змін до деяких законодавчих актів України щодо вдосконалення системи управління та дерегуляції у сфері земельних відносин". URL: https://zakon.rada.gov.ua/laws/show/1423-20\#Text

3. Зіновчук Н.В., Аесь А.В., Ращенко А.В. Мотиваційні чинники організації органічних сільськогосподарських кооперативів в Україні. Економіка АПК. 2016. № 9. С. 33-38.

4. Кипоренко В.В. Формування системи сертифікації органічного сільського господарства в Україні. Агросвіт. 2014. № 24. С. 28-34.

5. Павленко О.П., Аещенко О.Ю. Органічне природне агровиробництво в системі продовольчої безпеки держави та його фінансове забезпечення. Агросвіт. 2017. № 3. С. 17-24.

6. Федоров М.М., Ходаківська О.В., Корчинська С.Г. Розвиток органічного виробництва: монографія. К.: ННЦ IAE, 2011. 146 с.

7. Шкуратов O.І., Чудовська В.А., Вдовиченко А.В. Органічне сільське господарство: еколого-економічні імперативи розвитку. Монографія. К.: TOB AIA, 2015. 248 с.

\section{References:}

1. Hranovs'ka, V.H. (2017), "Mechanisms to stimulate the development of organic sector enterprises: adaptation of world experience", Ekonomika i suspil'stvo, vol. 9, pp. 384-390.

2. Verkhovna Rada of Ukraine (2021), The Law of Ukraine "On amendments to some legislative acts of Ukraine to improve the system of management and deregulation in the field of land relations", available at: https://zakon.rada.gov.ua/ laws/show/1423-20\#Text (Accessed 10 Sept 2021).

3. Zinovchuk, N.V. Les', A.V. and Raschenko, A.V. (2016), "Motivational factors of the organization of organic agricultural cooperatives in Ukraine", Ekonomika APK, vol. 9, pp. 33-38.

4. Kyporenko, V.V. (2014), "Formation of the certification system of organic agriculture in Ukraine", Ahrosvit, vol. 24, pp. 28-34.

5. Pavlenko, O.P. and Leschenko, O.Yu. (2017), "Organic natural agricultural production in the food security system of the state and its financial support", Ahrosvit, vol. 3, pp. 17-24.

6. Fedorov, M.M. Khodakivs'ka, O.V. and Korchyns'ka, S.H. (2011), Rozvytok orhanichnoho vyrobnytstva [Development of organic production], NNTs IAE, Kyiv, Ukraine.

7. Shkuratov, O.I. Chudovs'ka, V.A. and Vdovychenko, A.V. (2015), Orhanichne sil's'ke hospodarstvo: ekoloho-ekonomichni imperatyvy rozvytku [Organic agriculture: ecological and economic imperatives of development], TOV DIA, Kyiv, Ukraine. Стаття надійшла до редакиії 05.10.2021 p. 
А. М. Токарчук, к. е. н., Аоцент, Вінницький національний аграрний університет, м. Вінниця ORCID ID: 0000-0001-6341-4452

DOI: $10.32702 / 2306-6792.2021 .19 .31$

\title{
УАОСКОНААЕННЯ ОРГАНІЗАЦІЇ ПЕРЕРОБКИ ВІАХОАІВ НА БІОГАЗ ТА ТВЕРАЕ БІОПАЛИВО НА РІВНІ ГРОМАА В УКРАЇНI
}

\author{
D. Tokarchuk, \\ $\mathrm{PhD}$ in Economics, Associate Professor, Vinnytsia National Agrarian University, Vinnytsya
}

\section{IMPROVEMENT OF ORGANIZATION OF WASTE PROCESSING FOR BIOGAS AND SOLID FUEL AT THE COMMUNITY LEVEL IN UKRAINE}

Статтю присвячено дослідженню перспектив України в організації використання відходів громаАна енергетичні цілі. Визначено, що такий напрям поводження з органічними відходами практикується в країнах ЄС, де громади мають гарантії віА Аержави при реалізації біоенергетичних проєктів, а органи місцевого самоврядування активно сприяють їх впровадженню. Проаналізовано законодавство України щодо поводження з відходами, зокрема, Національну стратегії управління відходами в Україні до 2030 року та Національний план поводження з відходами до 2030 року, визначено, що енергетичне використання органічних відходів займає вагоме місце сереА ефективних напрямів утилізації, що відповідає європейським стандартам. Обгрунтовано, що сільські громади мають значний біоенергетичний потенціал відходів рослинництва і тваринництва, що утворені як сільськогосподарськими підприємствами так і в господарствах населення. Аналіз динаміки кількості установок для поводження з відходами в Україні у динаміці за 2016-2020 роки показав зменшення їх кількості, зокрема, установок Аля спалювання відходів з метою отримання енергії - на 159 одиниць у 2020 році порівняно з 2020 роком, зроблено висновки про необхідність активізації ефективного поводження з відходами. Запропоновано алгоритм проєктування використання відходів на енергетичні цілі на рівні громад в Україні, що включає стадії: первинна, первинне планування і започаткування, детальне планування і побудова, виробництво і оптимізація, подальший розвиток. Зроблено огляд заходів на кожному із запропонованих етапів з акцентом на необхідності популяризації біовиробництва серед населення громаА, співпраці з органами місцевого самоврядування, пошуку альтернативних шляхів фінансування біоенергетичних проєктів. Наведено Аосвід Німеччини у диверсифікації шляхів фінансування біоенергетичних проєктів на рівні громад та проаналізовано можливості його використання в Україні. Аосліджено можливі проблеми у реалізації проєктів з виробництва біогазу та твердого біопалива з відходів на рівні громад та можливі шляхи їх вирішення.

The article is devoted to the study of Ukraine's prospects in organizing the use of community waste for energy purposes. It is determined that this direction of organic waste management is practiced in the EU countries, where communities have guarantees from the state in the implementation of bioenergy projects, and local governments are actively promoting their implementation. The legislation of Ukraine on waste management is analyzed, in particular, the National Waste Management Strategy in Ukraine until 2030 and the National Waste Management Plan until 2030, it is determined that energy use of organic waste occupies an important place among effective areas of disposal that meets European standards. It is substantiated that rural communities have a significant bioenergy potential of crop and livestock waste generated by both agricultural enterprises and households. Analysis of the dynamics of the number of waste management facilities in Ukraine in the dynamics for 2016-2020 showed a decrease in their number, in particular, waste incineration plants for energy - by 159 units in 2020 compared to 2020 , concluded that the need to intensify efficient waste management. An algorithm of designing the use of waste for energy purposes at the community level in Ukraine is proposed, which includes

* Стаття включає результати досліджень відповідно до НАР "Розробка концепції забезпечення енергетичної безпеки та енергоефективності як пріоритетних напрямів сталого розвитку сільських територій" Вінницького національного аграрного університету (номер державної реєстрації 0121U109443). 
next stages: primary, primary planning and start-up, detailed planning and construction, production and optimization, further development. An overview of measures at each of the proposed stages is made with an emphasis on the need to promote bioproduction among the population of communities, cooperation with local governments, finding alternative ways to finance bioenergy projects. The experience of Germany in diversifying the ways of financing bioenergy projects at the community level is presented and the possibilities of its use in Ukraine are analyzed. It is concluded that funding from own sources is not available to most communities in Ukraine, especially small ones with a population of up to 10 thousand people. Possible problems in the implementation of projects for the production of biogas and solid biofuels from waste at the community level and possible ways to solve them are identified.

Ключові слова: відходи, біоенергетичні проєкти, громада, біогаз, тверде біопаливо, етапи проєктування.

Key words: waste, bioenergy projects, community, biogas, solid biofuels, design stages.

\section{ПОСТАНОВКА ПРОБЛЕМИ}

3 еволюцією енергетичних систем до зростання частки децентралізованої генерації та зростання попиту на електроенергію через електрифікацію, все більша кількість домогосподарств, підприємств, органів державної влади, міст та муніципалітетів готові брати участь як активні гравці в енергетичному переході. Цій тенденції сприяє зростання обізнаності споживачів (щодо цін на енергоносії, екологічні проблеми тощо) та технологічний розвиток у сфері виробництва відновлюваних джерел енергії.

Європейський союз має значний досвід в організації виробництва біопалива та енергії саме на рівні територіальних громад. Громадяни та енергетичні спільноти в ЄС тепер мають ряд гарантій, які забезпечують можливість інвестувати у відновлювані джерела енергії та отримувати вигоду від енергетичного переходу. Визнання їх ролі, підтримка та нові права виробляти, споживати, продавати та зберігати енергію з ВАЕ тепер закріплені в законодавстві ЄС. На практиці це означає:

a) окремі громадяни та енергетичні громади стають партнерами в енергетичній системі;

б) додаткові права громадянам та енергетичним громадам, що хочуть інвестувати в BAE;

в) встановлюються вимоги до національних законодавств щодо розробки засобів підтримки громадян та енергетичних громад;

г) вимагається спрощення адміністративних процедур щодо проєктів ВАЕ окремих громадян та енергетичних громад;

А) органи місцевого самоврядування - ключові гравці впровадження проєктів на місцевому рівні [1].

3 огляду на євроінтеграційні процеси, що мають місце в Україні, необхідним є поширення практики організації виробництва біопалива на рівні громад у нашій державі, що допоможе нам стати повноправним членом $€ \mathrm{C}$ з точки зору енергетичної безпеки та енергозабезпечення.

\section{АНАЛІЗ ОСТАННІХ ДОСЛІДЖЕНЬ І ПУБЛІКАЦІЙ}

Ефективне поводження з відходами $є$ предметом досліджень багатьох науковців, серед яких варто згадати Калетніка Г.М. [2], Березюка С.В. [3], Гончарук I.В. [2; 4], Паламаренко Я.В. [5], Пришляк Н.В. [3; 5; 6] та ін. Проте більшість науковців займаються менеджментом відходів або на рівні держави, або на рівні підприємств, які їх продукують і можуть використати для власної енергетичної автономізації.

Питання поводження з відходами на рівні громад в Україні є недостатньо вивченим, поодинокі впроваджені біоенергетичні проєкти $€$ скоріш винятком, аніж правилом, а для переважної більшості громад відходи залишаються не джерелом енергетичних ресурсів, а вагомою екологічною проблемою.

\section{МЕТА ДОСЛІДЖЕННЯ}

Мета дослідження - на основі врахування європейського досвіду удосконалити процес організації переробки відходів на біогаз та тверде біопаливо на рівні громад в Україні, що внесе свій вклад у їх сталий розвиток.

\section{ВИКЛАД ОСНОВНОГО МАТЕРІАЛУ ДОСЛІДЖЕНЬ}

На сьогодні не викликає сумнівів те, що ефективне поводження з відходами $€$ запорукою сталого розвитку як окремих громад, так і держави загалом. В Україні підтвердженням цьому є схвалення 8 листопада 2017 року Національної стратегії управління відходами в УКраїні до 2030 року.

Стратегія визначає головні напрями державного регулювання у сфері поводження 3 відходами в найближчі десятиліття з урахуванням європейських підходів з питань управління відходами, що базуються на положеннях:

- Рамкової Аирективи № 2008/98/ЄС 
Таблиця 1. Теоретичний та економічний біоенергетичний потенціал відходів рослинництва, що продукуються підприємствами та господарствами населення

в Україні, 2016-2020 рр.

\begin{tabular}{|c|c|c|c|c|c|c|}
\hline \multirow[b]{2}{*}{ Вид відходів } & \multicolumn{5}{|c|}{ Роки } & \multirow{2}{*}{$\begin{array}{c}\text { Відхи- } \\
\text { лення } \\
2020 \mathrm{p} . \\
\text { до } 2016 \mathrm{p} . \\
(+,-)\end{array}$} \\
\hline & 2016 & 2017 & 2018 & 2019 & 2020 & \\
\hline \multicolumn{7}{|c|}{$\begin{array}{c}\text { Відходи рослинництва (теоретичний біоенергетичний потенціал), } \\
\text { що продукуються на підприємствах тис. т: }\end{array}$} \\
\hline зернових культур (солома) & 28703,6 & 275163,9 & 253901,3 & 293176,7 & 254377,1 & 225673,5 \\
\hline кукурудзи на зерно (стебла) & 30314,2 & 265053,1 & 399178,8 & 398637,3 & 341643,3 & 311329,1 \\
\hline буряку цукрового (гичка) & 6674,5 & 71135,9 & 66583,2 & 48291,6 & 43135,7 & 36461,2 \\
\hline соняшнику (стебла) & 22287,2 & 201337,9 & 231678,0 & 248684,4 & 218365,9 & 196078,7 \\
\hline сої (солома) & 3599,6 & 32824,2 & 36918,7 & 30045,6 & 22601,2 & 19001,6 \\
\hline ріпак і кольза (солома) & 2246,2 & 43221,0 & 54417,6 & 64957,0 & 50595,0 & 48348,8 \\
\hline \multicolumn{7}{|c|}{$\begin{array}{c}\text { Економічний біоенергетичний потенціал відходів рослинництва, } \\
\text { що продукуються на підприємствах, тис. т: }\end{array}$} \\
\hline зернових культур (солома) & 8611,1 & 82549,2 & 76170,4 & 87953,0 & 76313,1 & 67702,1 \\
\hline кукурудзи на зерно (стебла) & 12125,7 & 106021,2 & 159671,5 & 159454,9 & 136657,3 & 124531,6 \\
\hline буряку цукрового (гичка) & 3337,2 & 35568,0 & 33291,6 & 24145,8 & 21567,8 & 18230,6 \\
\hline соняшнику (стебла) & 8914,9 & 80535,1 & 92671,2 & 99473,7 & 87346,3 & 78431,5 \\
\hline сої (солома) & 2879,6 & 26259,3 & 29535,0 & 24036,5 & 18080,9 & 15201,3 \\
\hline ріпак і кольза (солома) & 898,5 & 17288,4 & 21767,0 & 25982,8 & 20238,0 & 19339,5 \\
\hline \multicolumn{7}{|c|}{$\begin{array}{c}\text { Відходи рослинництва (теоретичний біоенергетичний потенціал), } \\
\text { що продукуються у господарствах населення, тис. т: }\end{array}$} \\
\hline зернових культур (солома) & 9310,0 & 9732,0 & 8866,0 & 9945,4 & 9205,3 & $-104,7$ \\
\hline кукурудзи на зерно (стебла) & 6182,8 & 5564,1 & 6623,5 & 6780,3 & 5213,1 & $-969,7$ \\
\hline буряку цукрового (гичка) & 331,0 & 327,5 & 325,5 & 273,0 & 261,5 & $-69,5$ \\
\hline соняшнику (стебла) & 3604,3 & 3114,1 & 3744,9 & 4113,5 & 3073,2 & $-531,1$ \\
\hline сої (солома) & 249,8 & 227,0 & 322,8 & 324,3 & 257,8 & 8,0 \\
\hline ріпак і кольза (солома) & 61,6 & 67,5 & 59,4 & 64,9 & 54,9 & $-6,7$ \\
\hline \multicolumn{7}{|c|}{$\begin{array}{c}\text { Економічний біоенергетичний потенціал відходів рослинництва, } \\
\text { що продукуються у господарствах населення, тис. т: }\end{array}$} \\
\hline зернових культур (солома) & 2793,0 & 2919,6 & 2659,8 & 2983,6 & 2761,6 & $-31,4$ \\
\hline кукурудзи на зерно (стебла) & 2473,1 & 2225,6 & 2649,4 & 2712,1 & 2085,2 & $-387,9$ \\
\hline буряку цукрового (гичка) & 165,5 & 163,8 & 162,8 & 136,5 & 130,8 & $-34,7$ \\
\hline соняшнику (стебла) & 1441,7 & 1245,6 & 1498,0 & 1645,4 & 1229,3 & $-212,4$ \\
\hline сої (солома) & 199,8 & 181,6 & 258,3 & 259,4 & 206,2 & 6,4 \\
\hline ріпак і кольза (солома) & 24,6 & 27,0 & 23,8 & 26,0 & 22,0 & $-2,7$ \\
\hline \multicolumn{7}{|c|}{ Загальний теоретичний потенціал, тис. т } \\
\hline Відходи рослинництва, разом & 113564,6 & 907768,1 & 1062619,7 & 1105293,9 & 948783,9 & 835219,3 \\
\hline \multicolumn{7}{|c|}{ Загальний економічний потенціал, тис. т } \\
\hline Відходи рослинництва, разом & 43864,8 & 354984,4 & 420358,6 & 428809,8 & 366638,6 & 322773,9 \\
\hline
\end{tabular}

Ажерело: сформовано автором за даними Аержавної служби статистики України [10].

Європейського парламенту та Ради від 19 листопада 2008 р. "Про відходи та скасування деяких директив";

-Аирективи Ради № 1999/31/ЄС від 26 квітня 1999 р. "Про захоронення відходів";

- Аирективи № 2006/21/ЄС Європейського парламенту та Ради від 15 березня 2006 р. "Про управління відходами видобувних підприємств, та якою вносяться зміни до Аирективи 2004/35/EC";

- Аирективи 94/62/ЄС Європейського парламенту та Ради від 20 грудня 1994 р. "Про упаковку та відходи упаковки";

- Аирективи 2012/19/ЕС Европейського парламенту та Ради від 4 липня 2012 р. "Про відходи електричного та електронного обладнання (BEEO)";

- Аирективи 2006/66/ЕС Європейського парламенту та Ради від 6 вересня 2006 р. "Про батарейки і акумулятори та відпрацьовані батарейки і акумулятори" [7].

На виконання Стратегї, Кабінет Міністрів України 20 лютого 2019 року затвердив Національний план управління відходами до 2030 року, який передбачає запровадження економічного стимулювання впровадження екологічно чистих технологій виробництва та розширення можливостей перероблення (рециклінгу), забезпечення функціонування централізованих потужностей для перероблення (рециклінгу) різних видів відходів [8].

Аля успішного впровадження означених документів необхідною $є$ розробка регіональних планів управління відходами з метою адаптації національної політики до масштабу регіонів та потреб громад. 
Особливе місце у ефективних напрямах поводження з відходами у Стратегії та Національному плані займає їх використання на виробництво енергії, оскільки це шлях до енергонезалежних громад та зменшення енергетичної залежності України. Значний енергетичний потенціал мають відходи сільського господарства та побутові відходи.

Цікавими з точки зору виробництва біопалива і енергії $є$ відходи як галузі рослинництва, так і тваринництва [9, с. 138], при цьому має враховуватися як потенціал сільськогосподарських підприємств, так і домогосподарств, оскільки вони можуть спільно використовуватися при реалізації біоенергетичних проєктів на рівні громад.

Аля обрахунку обсягу утворення відходів галузі рослинництва береться до уваги співвідношення між основною і побічною продукцією (відходами), отриманий обсяг складатиме теоретичний біоенергетичний потенціал. Економічний біоенергетичний потенціал відходів - та частина, яку економічно вигідно використовувати на енергетичні цілі. Аля окремих культур відсоток, який доцільно використовувати для виробництва біопалива і енергії різниться (солома зернових - 30\%, відходи кукурудзи на зерно, соняшнику, солома ріпаку та кользи - 40\%, відходи цукрового буряку $-50 \%$, відходи сої - $80 \%$ ) (табл. 1$)$. ккаїни [10]
Таблиця 2. Утворення відходів тваринництва у підприємствах та господарствах населення в Україні, на 31 грудня відповідного року, 2016-2020 рр.

\begin{tabular}{|c|c|c|c|c|c|c|}
\hline \multirow[b]{2}{*}{ Вид відходів } & \multicolumn{5}{|c|}{ Роки } & \multirow{2}{*}{$\begin{array}{c}\text { Відхи- } \\
\text { лення } \\
2020 \mathrm{p} . \\
\text { до } 2016 \mathrm{p} . \\
(+,-)\end{array}$} \\
\hline & 2016 & 2017 & 2018 & 2019 & 2020 & \\
\hline \multicolumn{7}{|c|}{ Відходи тваринництва, що продукуються на підприємствах, тис. т: } \\
\hline гній ВРX & 12383,6 & 11901,0 & 11610,3 & 10706,4 & 10287,2 & $-2096,4$ \\
\hline Гній свиней & 12835,8 & 11891,6 & 12222,8 & 11879,0 & 13064,7 & 228,9 \\
\hline гній кіз та овець & 205,9 & 205,7 & 200,5 & 185,4 & 166,4 & $-39,5$ \\
\hline пташиний послід & 6042,2 & 6190,2 & 6536,9 & 7029,9 & 6037,5 & $-4,7$ \\
\hline \multicolumn{7}{|c|}{ Відходи тваринництва, що продукуються у господарствах населення, тис. т: } \\
\hline гній ВРX & 25181,3 & 24587,6 & 22454,4 & 20836,5 & 19031,8 & $-6149,4$ \\
\hline гній свиней & 11170,2 & 10096,5 & 9464,0 & 8737,3 & 8087,2 & $-3083,0$ \\
\hline гній кіз та овець & 1240,1 & 1240,8 & 1196,1 & 1139,2 & 1087,8 & $-152,3$ \\
\hline пташиний послід & 5053,2 & 5074,8 & 5105,8 & 5100,9 & 5002,0 & $-51,2$ \\
\hline \multicolumn{7}{|c|}{ Загальний обсяг утворення відходів, тис. т } \\
\hline $\begin{array}{l}\text { Відходи } \\
\text { тваринництва, } \\
\text { разом }\end{array}$ & 74112,3 & 71188,2 & 68790,8 & 65614,6 & 62764,6 & $-11347,7$ \\
\hline
\end{tabular}

Ажерело: сформовано автором за даними Аержавної служби статистики

Таким чином, громади в Україні мають достатній обсяг відходів рослинництва, які можна ефективно використати для забезпечення енергетичних потреб.

За даними Аерженергоефективності, сьогодні частина соломи після збирання пресується у тюки, брикети та пелети і використовується для опалення. На 14 підприємствах олійної промисловості спалюється понад 500 тис. т лушпиння соняшнику і 120 тис. т його гранулюється [11].

Обсяг утворення відходів тваринництва в Україні має тенденцію до зменшення, оскільки

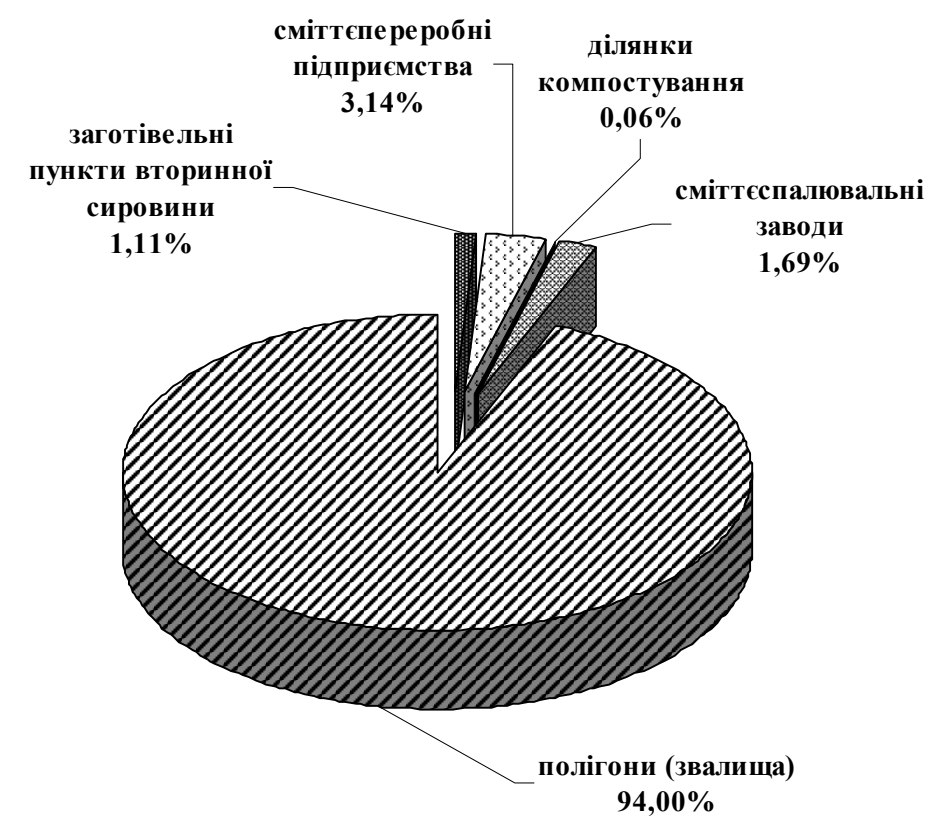

Рис. 1. Структура надходження побутових відходів на утилізацію чи захоронення в Україні, 2020 р., \%

Ажерело: сформовано автором за даними Міністерства розвитку громад та територій України [12]. 
Таблиця 3. Установки для поводження з відходами в Україні на кінець року, 2016-2020 рр.

\begin{tabular}{|c|c|c|c|c|c|c|c|c|c|c|c|c|}
\hline \multirow[b]{3}{*}{ Показник } & \multicolumn{10}{|c|}{ Роки } & \multirow{2}{*}{\multicolumn{2}{|c|}{$\begin{array}{c}2020 \text { p. } \\
\text { до } 2016 \text { p., +/- }\end{array}$}} \\
\hline & \multicolumn{2}{|c|}{2016} & \multicolumn{2}{|c|}{2017} & \multicolumn{2}{|c|}{2018} & \multicolumn{2}{|c|}{2019} & \multicolumn{2}{|c|}{2020} & & \\
\hline & 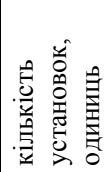 & 总 & 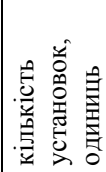 & 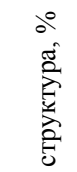 & 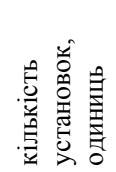 & 总 & 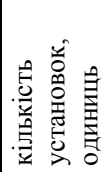 & 总 & 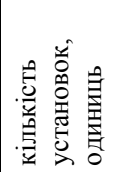 & 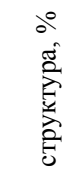 & 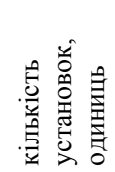 & 总 \\
\hline $\begin{array}{l}\text { Установки для } \\
\text { поводження } 3 \text { відходами, } \\
\text { усього, в т.ч.: }\end{array}$ & 2110 & 100,0 & 2159 & 100,0 & 2190 & 100,0 & 1023 & 100,0 & 782 & 100,0 & -1328 & $\mathrm{x}$ \\
\hline $\begin{array}{l}\text { для спалювання відходів } \\
3 \text { метою отримання } \\
\text { енергії }\end{array}$ & 493 & 23,4 & 556 & 25,8 & 584 & 26,7 & 520 & 50,8 & 334 & 42,7 & -159 & 19,4 \\
\hline $\begin{array}{l}\text { для спалювання відходів } \\
3 \text { метою теплового } \\
\text { перероблення відходів }\end{array}$ & 127 & 6,02 & 140 & 6,48 & 143 & 6,5 & 117 & 11,4 & 105 & 13,4 & -22 & 7,4 \\
\hline $\begin{array}{l}\text { для утилізації } \\
\text { (перероблення) відходів }\end{array}$ & 433 & 20,5 & 429 & 19,9 & 402 & 18,4 & 328 & 32,1 & 316 & 40,4 & -117 & 19,9 \\
\hline $\begin{array}{l}\text { інші установки для } \\
\text { видалення (крім } \\
\text { спалювання) відходів }\end{array}$ & 1057 & 50,1 & 1034 & 47,9 & 1061 & 48,4 & 58 & 5,7 & 27 & 3,5 & -1030 & $-46,6$ \\
\hline
\end{tabular}

Ажерело: сформовано автором за даними Аержавної служби статистики України [10].

поголів'я тварин скорочується (табл. 2). Проте він $€$ достатнім для реалізації проєктів з виробництва біогазу громадами, поєднуючи потенціал відходів тварин, що утримуються як підприємствами, так і господарствами населення.

Значний потенціал виробництва біопалива, зокрема, біогазу, має органічна фракція побутових відходів. За інформацію Міністерства розвитку громад та територій України в країні за 2020 рік утворилось понад 54 млн м³ побутових відходів, або понад 10 млн тонн, які за-

Таблиця 4. Етапи проєктування використання відходів на енергетичні цілі на рівні громад

\begin{tabular}{|c|c|c|}
\hline $\begin{array}{l}№ \\
\text { 유 }\end{array}$ & Стадія & Основні складові \\
\hline 1 & Первинна стадія & $\begin{array}{l}\text { Аналіз потенціалу відходів на виробництво } \\
\text { біопалива. } \\
\text { Аналіз потреб громади в енергетичних ресурсах. } \\
\text { Мотивація і довіра до біоенергетичних проєктів, } \\
\text { соціально-економічне прийняття проєктів }\end{array}$ \\
\hline 2 & $\begin{array}{l}\text { Первинне } \\
\text { планування і } \\
\text { започаткування }\end{array}$ & $\begin{array}{l}\text { Вибір організаційної форми компанії, що } \\
\text { займатиметься біовиробництво (кооператив, } \\
\text { акціонерне товариство, комунальні служби тощо). } \\
\text { Технічна розробка проєктів. } \\
\text { Пошук фінансової підтримки }\end{array}$ \\
\hline 3 & $\begin{array}{l}\text { Детальне } \\
\text { планування і } \\
\text { побудова }\end{array}$ & $\begin{array}{l}\text { Укладення договорів. } \\
\text { Порівняння альтернативних пропозицій. } \\
\text { Забезпечення фінансування }\end{array}$ \\
\hline 4 & $\begin{array}{l}\text { Виробництво і } \\
\text { оптимізація }\end{array}$ & $\begin{array}{l}\text { Навчання персоналу. } \\
\text { Оптимізація системи виробництво біопалива та } \\
\text { енергії з відходів. } \\
\text { Приєднання до системи енергозабезпечення на } \\
\text { основі біогазу та твердого біопалива об'єктів } \\
\text { соціальної інфраструктури громади та підприємств, } \\
\text { що постачатимуть сировину }\end{array}$ \\
\hline 5 & $\begin{array}{l}\text { Подальший } \\
\text { розвиток }\end{array}$ & $\begin{array}{l}\text { Інновації, вдосконалення біо- та енерговиробництва. } \\
\text { Доповнення системи енергопостачання іншими } \\
\text { альтернативними джерелами (напр. сонця, вітру). } \\
\text { Передача знань, поширення інформації серед інших } \\
\text { громад }\end{array}$ \\
\hline
\end{tabular}

Ажерело: узагальнено автором. хоронюються на 6 тис. сміттєзвалищ і полігонів загальною площею майже 9 тис. га. Майже $79 \%$ населення України охоплено послугами з вивезення побутових відходів. Найгірший показник охоплення населення послугами з вивезення побутових відходів у Кіровоградській області - 64,8\% та у Житомирській області $65,3 \%$. Завдяки впровадженню, в 1725 населеному пункті роздільного збирання побутових відходів, роботі 34 сміттєсортувальних ліній, 1 сміттєспалювального заводу і 3 сміттєспалювальних установок перероблено та утилізовано близько 6,0\% побутових відходів (рис. 1) [12].

94\% побутових відходів надійшло на полігони (звалища), корисна утилізація: $1,11 \%$ - потрапило на заготівельні пункти вторинної сировини, $3,14 \%$ - на сміттєпереробні підприємства, 0,06\% - на ділянки компостування, $1,7 \%$ - спалено на спеціалізованих заводах.

Аналіз динаміки кількості і структури установок для поводження з відходами в Україні (табл. 3), показав теденцію до зменшення кількості таких установок у 2020 році порівняно з 2016 роком за усіма напрямами поводження з відходами: для спалювання відходів 3 метою отримання енергії - на 159 одиниць, для спалювання відходів з метою теплового перероблення відходів - на 22 одиниць, для утилізації (перероблення) відходів — на 117 одиниць та на 1030 одиниць - інших установок для видалення відходів (крім спалювання).

За експертними оцінками на 26 полігонах України влаштовано системи вилучення біогазу та експлуатуються установки 


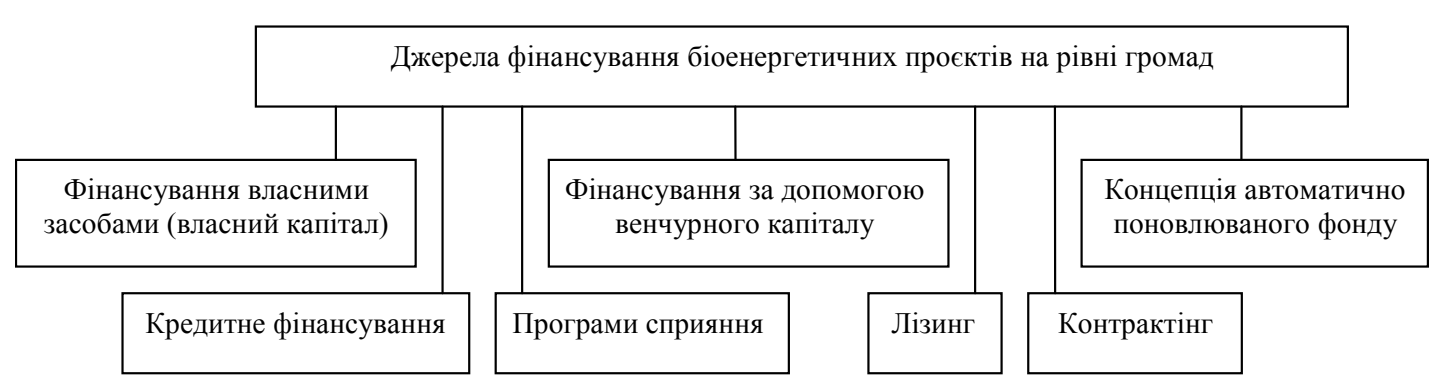

Рис. 2. Джерела фінансування біоенергетичних проєктів громад у Німеччині

Ажерело: узагальнено автором.

для виробництва електроенергії, потужність яких досягла $30 \mathrm{MB}$ т. Кількість утилізованого біогазу у 2020 році склала 64,0 млн м³ $(50 \%$ метану). Кількість виробленої у 2020 році електроенергї̈ - 112,3 ГВт год [12].

Організація переробки відходів сільського господарства та побутових відходів на біопаливо (біогаз, пелети, брикети) є важливим кроком у вирішенні екологічних проблем та забезпечення громад власними енергетичними ресурсами.

Під час реалізації проєктів з використання відходів на виробництво біопалива в громадах необхідною передумовою є детальне проєктування (табл. 4).

1. Первинна стадія проєктування використання біовідходів на виробництво біопалива і енергії передбачає, передусім мотивування окремих ініціаторів, якими можуть бути жителі громади, фермери, представники підприємств. Від рівня їх зацікавленості та обізнаності в біоенергетиці багато в чому залежатиме успіх проєкту.

Важливим початковим етапом $є$ аналіз потенціальної сировини, наявної на території громади. При цьому до уваги потрібно брати увесь потенційний обсяг відходів органічного походження, який продукується як сільськогосподарськими підприємствами, так і населенням.

В ідеальному варіанті дані щодо обсягів утворення відходів, їх морфологічний склад, про кількість оброблення та захоронення відходів розробники проєкту мають отримати з таких офіційних джерел:

- дані статистичного обліку, отримані за достовірними результатами постійно функціонуючої системи обліку (у т.ч. за даними зважування відходів, що надходять на полігон ТПВ або на інші об'єкти оброблення відходів);

- дані експериментальних досліджень обсягів утворення відходів в населених пунктах та сільськогосподарських підприємствах;

- дані експериментальних досліджень морфологічного складу відходів від різних категорій утворювачів в населених пунктах.

На практиці в областях України такі дані, як правило, або відсутні, або носять фрагмен- тарний характер, що не дозволяє покласти їх в основу аналізу [13].

Аля правильної оцінки біоенергетичного потенціалу громади доцільно звернутися за кваліфікованою допомогою до спеціалізованих науково-дослідних установ чи 3ВО, які займаються дослідження ефективності впровадження біоенергетичних проєктів на госпрозрахункових засадах.

Аналіз потреб громади в енергетичних ресурсах передбачає аналіз енергетичних потреб як об'єктів соціальної інфраструктури громади, так і населення та підприємств, що продукують відходи і будь постачати їх в якості сировини для біовиробництва. На практиці це приблизно 50\% будівель великих громад і $80 \%$ - малих.

Соціально-економічне ухвалення рішень за або проти біоенергетичних проєктів залежить від:

- прогнозної рентабельності проєкта/ проєктів;

- усвідомлення вартості і ефекту зайнятості (прибуток керівників виробництвом, дохід від оренди, податкові надходження, створюються нові робочі місця, зменшується імпорт палива).

2. Первинне планування і започаткування передбачає створення робочих груп та діяльність за такими напрямами:

- забезпечення сировинним потенціалом, переговори з постачальниками, укладення попередніх договорів;

- укладення договорів по приєднанню до локальної мережі;

- вибір організаційної форми, розробка цінової моделі і можливостей участі;

- встановлення контакту з уповноваженим банком чи іншим інвестором, визначення можливостей підтримки і можливостей участі громадян;

- розробка технічного концепту, вирівнювання потенціалу, огляд установок, вибір моделі забезпечення;

- робота з громадськістю, особливо контакт із громадянами (поширення інформації, підвищення сприйняття, активна участь). 
У зв'язку з низьким рівнем кредитоспроможності громад і високою вартістю біоенергетичних проєктів, часто не легко забезпечити фінансування. Особливо на початковій фазі проєктам, що реалізовуються на громадських засадах, не вистачає матеріальних засобів для мобілізаційних кампаній, проведення зустрічей, створення перших техніко-економічних обгрунтувань і так далі. Місцеві органи влади можуть надати фінансову підтримку цим проєктам, які ще не отримали ніякого доходу. Отримання гарантій і фінансової підтримки 3 боку місцевої влади може сприяти кредитоспроможності проєктів з біоенергетики.

Європейський досвід, зокрема, досвід Німеччини показує, що джерела фінансування проєктів з виробництва біопалива з відходів на рівні громад можуть бути різноманітними (рис. 2).

1. Фінансування власними засобами (власний капітал). У загальному потреба у власному капіталі біоенергетичних проєктів складає 10$30 \%$. На практиці 70\% громад у Німеччині не здатні вносити необхідний власний капітал.

2. Кредитне фінансування. Кредити найчастіше використовувана форма фінансування для проєктів 3 альтернативних джерелами енергії. Потенційними кредиторами є: федеральні, державні і крупні банки, ощадні банки і кооперативні банки та інші. При використанні послуг регіональних банків (кооперативні і ощадні банки) частина відсотків залишається в регіоні і збільшує додану вартість.

3. Програми сприяння. В країнах ЄС гранти видаються в різних формах - дотації, кредити по вигідних відсотках з дотаціями на погашення або пайовими зобов'язаннями. Гранти можна різним чином комбінувати і нагромаджувати. Подача заявок проводиться на різних рівнях і в різних організаціях, залежно від походження фінансових коштів стимулювання.

Існує підтримка:

- розробок, техніко-економічних обгрунтувань і аналізу потенціалу (серед інших німецький державний банк (KFW), ініціатива по охороні клімату, Європейський фонд регіонального розвитку (EFRE), LEADER).

- інвестиції (серед інших німецький державний банк (KFW), інноваційної програми охорони навколишнього середовища, програми стимулювання ринку).

- постачання електроенергії з альтернативних джерел (Федеральний закон про поновлювані джерела енергії, EEG).

4. Фінансування за допомогою венчурного капіталу. Надається статутний капітал $з$ характеристиками власного капіталу на обмежений термін, він обкладається порівняно високими процентними ставки; мито йде з регіону.

Статутний капітал використовується в тих випадках, коли інші форми фінансування недоступні.

5. Концепція автоматично поновлюваного фонду. Концепція $є$ інноваційним способом сприяння і формою фінансування на території федеральних земель, заходи сприяння довше залишаються в системі і можуть неодноразово використовуватися. Таким чином, на відміну від сприяння, заснованого на дотаціях, можна запустити багатократні інвестиції.

6. Контрактінг. За даної форми часткові завдання даються спеціалізованим підприємствам. Це особлива форма фінансування, яка грунтується на приведенні до виконання певних видів робіт підрядчика.

7. Аізинг. Аізинг - це договір оренди матеріальних благ з подальшим відшкодуванням, це щадна для нерухомості форма, оскільки не потрібно брати кредит. Аізингодавець часто бере на себе заплановані витрати і має у своєму розпорядженні необхідні ноу-хау для успішної реалізації проєкту.

В умовах України фінансування власними засобами проєктів з використання відходів на виробництво біопалива недоступне для переважної більшості громад. Підтвердженням цього є результати аналізу дотаційності бюджетів 806 ОТГ України у 2020 році, які були згруповані за критерієм чисельності населення. Експертами було виділено 5 груп ОТГ з чисельністю населення: 1 - понад 15 тис. жителів; 2 від 10 до 15 тис. жителів; 3 - від 5 до 10 тис. жителів; 4 - менше 5 тис. жителів; 5 - ОТГміста обласного значення.

Найменш залежними від дотаційних ресурсів $з$ державного бюджету є громади - міста обласного значення з групи 5, в яких із 43 ОТГ найвищий рівень дотаційності становить 22,0\%. У групі 1 найвищий рівень дотаційності становить $54,4 \%$. Серед ОТГ групи $2-$ по 7 громадах показник дотаційності перевищує 50\% (або 5,2\% від загальної кількості громад у групі), найвище значення становить $61,5 \%$. У групі 3 по 13 громадах показник дотаційності перевищує $50 \%$ (або 4,7\% від загальної кількості громад у групі), найвище значення становить $64,0 \% . У$ групі 4 лише у 3 громадах показник дотаційності перевищує $50 \%$ (або 1,0\% від загальної кількості громад у групі), найвище значення становить 60,6\% [14].

Зважаючи на високий відсоток дотаційності бюджетів громад зрозуміло, що для них реалізувати великі біоенергетичні проєкти власни- 
ми силами практично неможливо, особливо це стосується невеликих громад 3 чисельністю населення до 10 тис. жителів.

Кредитне фінансування також є ненадійним Ажерелом фінансування проєктів з енергетичного використання відходів, оскільки умови кредитування та високі відсоткові ставки, що пропонуються українськими банками, є неприйнятними для громад.

Цікавим варіантом може бути звернення до міжнародних фінансових організацій, які надають кредити на пільгових умовах у рамках програм для проєктів з енергоефективності і поновлюваної енергетики (ЕБРР: програма фінансування альтернативної енергетики в Україні (USELF), програма Північнӧ̈ Екологічнӧ̈ Фінансової Корпорації (NEFCO), програма інвестицій IFC Групи Всесвітнього Банку, програми Інвестиційних фондів під управлінням Компанії Conning Assets Management Limited [15]).

3. Стадія детального планування і будівництва включає такі етапи:

- укладення спільних договорів - укладення договорів теплопостачання із споживачами тепла і договорів доставки 3 постачальниками палива;

- роз'яснення фінансування - подача договорів про сприяння, кредитних договорів;

- планування дозволів - складання заявки на будівництво, при необхідності - отримання дозволів згідно екологічного законодавства України;

- планування реалізації з процедурою надання державних замовлень - виготовлення документації по конкурсних замовленнях;

- передача замовлень на будівництво і його початок;

- прийом будівельних робіт і введення в експлуатацію біоенергетичних установок.

Важливим завданням цієї стадії є вибір оптимального устаткування та компанії, яка зробить якісне проєктування та вчасно здасть в експлуатацію біоенергетичні установки.

4. Стадія виробництві і оптимізації передбачає:

- навчання персоналу, що обслуговуватиме біоенергетичні об'єкти. Часто компанії-виробники обладнання окрім послуг з будівництва установки пропонують і навчання майбутніх працівників. Аля громади - це можливість створення нових робочих місць Аля місцевого населення;

- оптимізації системи виробництва біопалива і енергії з відходів - експлуатація установок дозолить $з$ часом вибрати найощадніші та найефективніши режими роботи устаткування;
- подальше розширення мережі - приєднання більшої кількості об'єктів, що використовуватимуть отриману біоенергетичну продукцію для забезпечення власних потреб.

5. Стадія подальшого розвитку передбачає, що громади впроваджуватимуть інноваційні ідё̈, вдосконалюватимуть технології біовиробництва. В майбутньому можливе збільшення потужності у разі приєднання додаткових джерел отримання відходів (наприклад, кооперація з сусідніми громадами). Аоповненням біоенергетичних систем на основі відходів можуть статі і інші проєкти з використання альтернативних джерел енергії для самозабезпечення громад - енергії соня, вітру, виробництва біодизелю тощо. Важливим є поширення інформації про успіх громади в енергетичній сфері, оскільки це сприятиме популяризації біоенергетики і вирішенню питань ефективного поводження з відходами інших громад.

Аля успішного втілення алгоритму розробки і реалізації громадами проєктів з використання відходів на виробництво біопалива необхідним є вирішення цілого ряду проблем:

- Сортування відходів. Якщо громади прагнуть зменшити кількість сміттєзвалищ та практикувати енергетичне використання відходів за пркладом європейських стандартів, необхідно навчати населення розумно сортувати сміття, що сприятиме зменшенню потоку відходів, що потрапляють на сміттєзвалища, а також економї̈ на сортувальних лініях. Аби забезпечити потік відходів на енергетичні цілі, необхідно розширити кількість домогосподарств, які мають укладені договори на вивезення побутових відходів та, що важливо - оплачують ці послуги. І це є проблемою, яка стоїть перед сільськими громадами, навіть для спроможних ОТГ.

— Забезпечення комунікації між виробниками відходів та підприємствами, що їх перероблятимуть. Маючи достатню кількість відсортованого сміття, громада може розраховувати на партнерство із переробним бізнесом, який буде його купувати. Підприємці, які працюють у цьому бізнесі, намагаються заручитися гарантіями від місцевої влади, що вона зможе забезпечити їх належною кількістю сировини, адже тільки так інвестиції зможуть окупитися.

- Співпраця 3 іншими громадами. Якщо власного сміття для переробних підприємств не вистачає, громади мають домовлятися із сусідами. Окрім того, регіональні плани передбачатимуть координацію в управлінні відходами між кількома громадами в межах одного кластеру, яких оціночно може бути від 3 до 8 на весь 
регіон. А це може бути реалізовано через механізми співробітництва територіальних громад. Саме це має допомогти об'єднати зусилля та організувати раціональну практику збирання та перероблення [16].

\section{ВИСНОВКИ}

Сталий розвиток громад неможливий без енергоефективних технологій та самозабезпечення енергетичними ресурсами. Потенціал сільських територій України у використанні відходів для виробництва біогазу, твердого біопалива чи енергії $€$ надзвичайно високим. Кооперація між жителями громад і сільськогосподарськими підприємствами на їх території може бути потужним драйвером у вирішенні екологічних проблем, пов'язаних з накопиченням органічних відходів, та перетворення їх на енергетичні ресурси.

Сьогодні лише спроможні громади здатні реалізовувати біоенергетичні проєкти, проте, навіть вони не мають досвіду у проєктуванні, рівень обізнаності населення у перевагах біовиробництва є низьким, недостатньою є співпраця з потенційними інвесторами та не налагоджено державно-приватне партнерство.

Цікавим може бути досвід європейських країн у використанні громадами енергетичного потенціалу відходів та диверсифікації джерел фінансування проєктів з біовиробництва. Пропонований алгоритм проєктування використання відходів на енергетичні цілі на рівні громад в Україні $є$ запорукою найбільш повного використання усіх можливостей громади: сировинного потенціалу, фінансових ресурсів, трудового потенціалу заради енергетичної незалежності та подальшого розвитку.

$\Lambda$ ітература:

1. Офіційний веб-сайт Біоенергетичної асоціації України. URL: https://uabio.org/ (дата звернення: 20.09.21).

2. Kaletnik G., Honcharuk I., Okhota Yu. The Waste-Free Production Development for the Energy Autonomy Formation of Ukrainian Agricultural Enterprises. Journal of Environmental Management and Tourism, 2020. Vol. XI, № 3 (43). P. 513-522. DOI: https://doi.org/ 10.14505//jemt.v11.3(43).02

3. Berezyuk S., Tokarchuk D., Pryshliak N. Resource potential of waste usage as a component of environmental and energy safety of the state. Journal of Environmental Management and Tourism. 2019. Vol. X, Issue 5 (37). P. 1157-1167. DOI: https://doi.org/10.14505//jemt.v10.5(37).23

4. Honcharuk I. Use of wastes of the livestock industry as a possibility for increasing the efficiency of AIC and replenishing the energy balance. Visegrad Journal on Bioeconomy and Sustainable Development. 2020. Vol. 9. № 1. P.914. DOI: https://doi.org/10.2478/vjbsd-2020-0002

5. Пришляк Н.B., Токарчук А.М., Паламаренко Я.В. Забезпечення енергетичної та екологічної безпеки держави за рахунок біопалива з біоенергетичних культур і відходів: монографія. Вінниця: Консоль, 2019. 336 с.

6. Pryshliak N., Lutsiak V., Tokarchuk D., \& Semchuk I. The Empirical research of the potential, awareness and current state of agricultural waste use to ensure energy autonomy of agricultural enterprises of Ukraine. Journal Of Environmental Management And Tourism. 2020. Vol. XI, № 7 (47). P. 1634-1648. DOI: https:// doi.org/10.14505//jemt.v11.7(47).04

7. Про схвалення Національної стратегії управління відходами в Україні до 2030 року: Розпорядження Кабінету Міністрів України від 8 листопада 2017 р. № 820-p. URL: https:// zakon.rada.gov.ua/laws/show/820-2017\%D1\%80\#Text (дата звернення: 22.09.21).

8. Про затвердження Національного плану управління відходами до 2030 року: Розпорядження Кабінету Міністрів України від 20 лютого 2019 p. № 117-p. URL: https://www.kmu.gov.ua/npas/pro-zatverdzhennya-nacionalnogoplanu-upravlinnya-vidhodami-do-2030-roku (дата звернення: 20.09.21).

9. Токарчук А.М. Управління ефективним використанням сільськогосподарських відходів Аля виробництва біогазу. Облік і фінанси. 2018. № 3 (81). С. $133-139$.

10. Офіційний веб-сайт Аержавної служби статистики України. URL: http://www.ukrstat.gov.ua/ (дата звернення: 10.09.21).

11. Тепло з біопалива для вашої родини та громади. Аерженергоефективності. URL: https://saee.gov.ua/sites/default/files/Heat biomass_ua.pdf (дата звернення: 25.09.21).

12. Стан сфери поводження з побутовими відходами в Україні за 2020 рік: Міністерство розвитку громад та територій України. URL: https://www.minregion.gov.ua/napryamki-diyalnosti/zhkh/terretory/stan-sfery-povodzhennyaz-pobutovymy-vidhodamy-v-ukrayini-za-2020rik-2/ (дата звернення: 22.09.21).

13. Аазненко А.О. Визначення параметрів утворення побутових відходів у населених пунктах України для цілей регіонального планування. Київ, 2019 р. URL: https://despro.org.ua/ library/publication/ \%D0 $\% 9 \mathrm{~F} \% \mathrm{D} 0 \% \mathrm{~B} 0 \% \mathrm{D} 1 \%$ $80 \% \mathrm{D} 0 \% \mathrm{~B} 0 \% \mathrm{D} 0 \% \mathrm{BC} \% \mathrm{D} 0 \% \mathrm{~B} 5 \% \mathrm{D} 1 \% 82 \%-$ D1 $\% 80 \% \mathrm{D} 0 \% \mathrm{~B} 8 \% 20 \% \mathrm{D} 1 \% 83 \% \mathrm{D} 1 \% 82 \% \mathrm{D} 0 \%-$ B $2 \% \mathrm{D} 0 \% \mathrm{BE} \% \mathrm{D} 1 \% 80 \% \mathrm{D} 0 \% \mathrm{~B} 5 \% \mathrm{D} 0 \% \mathrm{BD} \%-$ 
$\mathrm{D} 0 \% \mathrm{BD} \% \mathrm{D} 1 \% 8 \mathrm{~F} \% 20 \% \mathrm{D} 0 \% \mathrm{BF} \% \mathrm{D} 0 \% \mathrm{BE} \%$ D0\%B1\%D1\%83\%D1\%82\%D0\%BE \%D0\%B2\%D0\%B $8 \% \mathrm{D} 1 \% 85 \% 20 \% \mathrm{D} 0 \% \mathrm{~B} 2 \% \mathrm{D} 1 \% 96 \% \mathrm{D} 0 \%-$ B4\%D1 $\% 85 \% \mathrm{D} 0 \% \mathrm{BE} \% \mathrm{D} 0 \% \mathrm{~B} 4 \% \mathrm{D} 1 \% 96 \% \mathrm{D} 0 \% \mathrm{~B} 2$. pdf. (дата звернення: 25.09.21).

14. 3 якими фінансовими показниками закінчили 2020 рік об'єднані громади - рейтинг. Аецентралізація. URL: https://decentralization.gov.ua/news/13333 (дата звернення: 29.09.21).

15. Токарчук A.M. Інвестиційне забезпечення виробництва біогазу сільськогосподарськими підприємствами України. Економіка, фінанси, менеджмент: актуальні питання науки і практики. 2016. № 12 (16). С. 26-35.

16. Що громадам робити з відходами. Аецентралізація. URL: https://decentralization.gov.ua/ news/ 9291 (дата звернення: 29.09.21).

\section{References:}

1. The official website of the of the Bioenergy Association of Ukraine (2021), available at: https:/ /uabio.org/ (Accessed 20 Sept 2021).

2. Kaletnik, G. Honcharuk, I. and Okhota, Yu. (2020), "The Waste-Free Production Development for the Energy Autonomy Formation of Ukrainian Agricultural Enterprises", Journal of Environmental Management and Tourism, vol. XI, no. 3 (43), pp. 513-522.

3. Berezyuk, S. Tokarchuk, D. and Pryshliak, N. (2019), "Resource Potential of Waste Usage as a Component of Environmental and Energy Safety of the Sate", Journal of Environmental Management and Tourism, vol. X, no. 1 (33), pp. 149-160.

4. Honcharuk, I. (2020), "Use of wastes of the livestock industry as a possibility for increasing the efficiency of AIC and replenishing the energy balance". Visegrad Journal on Bioeconomy and Sustainable Development, vol. 9. no. 1, pp. 9-14.

5. Pryshliak, N.V. Tokarchuk, D.M. and Palamarenko, Y.V. (2019), Zabezpechennia enerhetychnoi ta ekolohichnoi bezpeky derzhavy za rakhunok biopalyva z bioenerhetychnykh kultur i vidkhodiv [Ensuring energy and environmental security of the state through biofuels from bioenergy crops and waste], Console, Vinnytsia, Ukraine.

6. Pryshliak, N., Lutsiak, V., Tokarchuk, D. and Semchuk, I. (2020), "The Empirical research of the potential, awareness and current state of agricultural waste use to ensure energy autonomy of agricultural enterprises of Ukraine", Journal Of Environmental Management And Tourism, vol. XI, no. 7 (47), pp. 1634-1648.

7. Cabinet of Ministers of Ukraine (2017), Resolution "On approval of the National Waste Management Strategy in Ukraine until 2030", available at: https://zakon.rada.gov.ua/laws/ show/820-2017-\%D1\%80\#Text (Accessed 22 Sept 2021).

8. Cabinet of Ministers of Ukraine (2019), Resolution "On approval of the National Waste Management Plan until 2030", available at: https:/ /www.kmu.gov.ua/npas/pro-zatverdzhennyanacionalnogo-planu-upravlinnya-vidhodami-do2030-roku (Accessed 20 Sept 2021).

9. Tokarchuk, D.M. (2018). "Management of efficient use of agricultural waste for biogas production", Oblik i finansy, vol. 3 (81), pp. 133-139.

10. The official website of the of the State Statistics Service of Ukraine (2021), available at: http://www.ukrstat.gov.ua/ (Accessed 10 Sept 2021).

11. State Agency on Energy Efficiency and Energy Saving of Ukraine (2021), "Biofuel heat for your family and community", available at: https:/ /saee.gov.ua/sites/default/files/Heat_biomass_ua.pdf (Accessed 25 Sept 2021).

12. Ministry of Development of Communities and Territories of Ukraine (2021), "The state of the sphere of household waste management in Ukraine for 2020", available at: https://www.minregion.gov.ua/napryamki-diyalnosti/zhkh/terretory/stan-sfery-povodzhennya-z-pobutovymyvidhodamy-v-ukrayini-za-2020-rik-2/ (Accessed 22 Sept 2021).

13. Laznenko, D.O. (2019), "Determination of parameters of household waste generation in settlements of Ukraine for the purposes of regional planning", available at: https://despro.org.ua/ library/publication/ \%D0\%9F\%D0\%B0\%D1\%$80 \% \mathrm{D} 0 \% \mathrm{~B} 0 \% \mathrm{D} 0 \% \mathrm{BC} \% \mathrm{D} 0 \% \mathrm{~B} 5 \% \mathrm{D} 1 \% 82 \% \mathrm{D} 1 \%-$ $80 \%$ D $0 \%$ B $8 \% 20 \%$ D $1 \% 83 \%$ D $1 \% 82 \%-$ $\mathrm{D} 0 \% \mathrm{~B} 2 \% \mathrm{D} 0 \% \mathrm{~B} \mathrm{E} \% \mathrm{D} 1 \% 80 \% \mathrm{D} 0 \% \mathrm{~B} 5$ $\% \mathrm{D} 0 \% \mathrm{BD} \% \mathrm{D} 0 \% \mathrm{BD} \% \mathrm{D} 1 \% 8 \mathrm{~F} \% 20 \% \mathrm{D} 0 \% \mathrm{BF} \%-$ D $0 \%$ B E \% D $0 \%$ B 1 \% D $1 \% 83 \%$ D $1 \% 82 \%-$ $\mathrm{D} 0 \% \mathrm{BE} \% \mathrm{D} 0 \% \mathrm{~B} 2 \% \mathrm{D} 0 \% \mathrm{~B} 8 \% \mathrm{D} 1 \% 85 \%$ $20 \% \mathrm{D} 0 \% \mathrm{~B} 2 \% \mathrm{D} 1 \% 96 \% \mathrm{D} 0 \% \mathrm{~B} 4 \% \mathrm{D} 1 \% 85 \%$ D0\%BE\%D0\%B4\%D1\%96\%D0\%B2.pdf (Accessed 25 Sept 2021).

14. Decentralization (2021), "Financial indicators with which the united communities end 2020 - rating", available at: https://decentralization.gov.ua/news/13333 (Accessed 29 Sept 2021).

15. Tokarchuk, D. M. (2016), "Investment support for biogas production by agricultural enterprises of Ukraine", Economy, finances, management: current issues of science and practice, vol.12, pp. 26-35.

16. Decentralization (2018), "What should communities do with waste", available at: https://decentralization.gov.ua/news/ 9291 (Accessed 25 Sept 2021).

Стаття надійшла до редакиії 03.10.2021 p. 
УAK 322.2

I. О. УАовенко,

к. е. н., доцент, доцент кафедри геодезії, картографії та кадастру,

Уманський націонадьний університет садівництва

ORCID ID: 0000-0001-5971-8365

М. В. Шемякін,

к. с.-г. н., Аоцент, доцент кафедри геодезії, картографії та каАастру,

Уманський національний університет садівництва

ORCID ID: 0000-0002-8323-5053

C. I. Кононенко,

ст. викладач, ст. викладач кафедри геодезії, картографії та кадастру,

Уманський національний університет садівництва

ORCID ID: 0000-0001-6060-2589

М. В. Мельник,

студентка, Уманський національний університет садівництва

ORCID ID: 0000-0001-7362-3688

DOI: $10.32702 / 2306-6792.2021 .19 .41$

\title{
ІСТОРІЯ ЗЕМЛЕУСТРОЮ УКРАЇНИ: ВIА СТАРОААВНIX ЧАСІВ АО СЬОГОАЕННЯ
}

\author{
I. Udovenko, \\ $\mathrm{PhD}$ in Economics, Associate Professor, Associate Professor of the Department \\ of Geodesy, Cartography and Cadastre, Uman National University of Horticulture \\ M. Shemyakin, \\ $\mathrm{PhD}$ in Agricultural Sciences, Associate Professor, Associate Professor of the Department \\ of Geodesy, Cartography and Cadastre, Uman National University of Horticulture \\ S. Kononenko, \\ Senior Lecturer, Senior Lecturer of the Department of Geodesy, Cartography \\ and Cadastre, Uman National University of Horticulture \\ M. Melnyk, \\ Student, Uman National University of Horticulture
}

\section{HISTORY OF LAND MANAGEMENT IN UKRAINE: FROM ANCIENT TIMES TO THE PRESENT}

У статті зАійснено екскурс в історичному ракурсі щодо виникнення та становлення землеустрою як основного методу організації управління земельними ресурсами. Зазначено, що земля як основний засіб реалізації земельних відносин набуває значення основного фактору розвитку та надає переважного статусу своєму власнику в будь-якому суспільстві, за будь-яких умов чи періоду суспільного розвитку. Незалежно від історичного розвитку господарських форм суспільства, способи виробництва підпорядковуються саме земельним відносинам, а саме тим їх формам, які окресленні та продиктовані відповідним змістом землеустрою. Тобто саме землеустрій скеровує способи використання наявних земельних ресурсів, їх регулювання у чітку і збалансовану систему заходів щодо організації управління та охорони земель. 
Визначено та проаналізовано позитивні та негативні наслідки щодо зняття мораторію на продаж землі та запровадження вільного обігу земельних ресурсів. Актуалізується постулат, що землеустрій виступає як державний важіль регулювання землеволодіння і землекористування при будь-яких змінах земельних відносин. Практична цінність дослідження полягає в аналізі історичних етапів становлення землеустрою як пріоритетного методу управління земельними ресурсами та хронологічне впорядкування основних законодавчих і нормативних актів, які справили свій вплив на формування сучасного типу провадження сучасного землеустрою, а також економічний стан земельноресурсного потенціалу на території нашої держави.

The country's land resource potential should have a well-established algorithm of interaction with all industries and spheres of management. In this regard, according to the authors, it is necessary to study the historical and chronological course of formation and development of land management as an independent economic mechanism and its impact on the modern type of management in the context of the reformist policy of the government, which is now relevant for our state.

The article provides an excursion in the historical perspective on the emergence and formation of land management as the main method of organizing land management. The review of the relevant legislative and regulatory acts on the regulation of land relations on the territory of Ukraine is carried out in chronological order. Attention is accented on close connection of the system of administrative management of characteristic for the corresponding historical period of community development and by the ways of organization of the landed relations in the field of management. Positive and negative consequences are marked, in opinion of authors, removal of moratorium on the sale of earth and input of free turnover of the landed resources. The current state of land management, as well as possible changes in land legislation in connection with the future lifting of the moratorium on land sales have been identified. Outlines the main characteristics of the current state of land management and possible changes in land legislation due to the future lifting of the moratorium on land sales. The main aspects of the functional features of the legal regulation of land relations are highlighted. The postulate that land management acts as the state lever of regulation of land tenure and land use at any changes of the land relations is actualized. The practical value of the study lies in the analysis of historical stages of land management as a priority method of land management and the chronological ordering of the main laws and regulations that have influenced the formation of a modern type of modern land management, as well on the economic condition of land resources in our country.

Ключові слова: земля, землеустрій, регулювання, функиіи, огранізачія, земельні відносини. Key words: land, land management, regulation, functions, organization, land relations.

\section{ПОСТАНОВКА ПРОБЛЕМИ}

Земля - основне національне багатство. Як об'єкт нерухомості, вона має особливий правовий статус та є об'єктом суспільно-економічних відносин. Землеустрій в свою чергу виконує важливі функції організації раціонального використання земельних ресурсів, їх охорони та захисту. Він $є$ однією із функцій держав ного управління в сфері землекористування і поширюється на землі всіх форм власності. Одним з основних методів управління земельними ресурсами на регіональному та місцевому рівнях є землеустрій.

Система управління земельними ресурсами у сучасних умовах еволюційного розвитку суспільних відносин стала більш вузько направленою та більш скорегованою на вирішенні завдань держави більш у галузевому вираженні.
Під час широкомасштабних земельних і економічних перетворень, якими є аграрна і земельна реформи, повсюдної реорганізації виробництва і територій, перерозподілу земель першочергового значення набуває землеустрій. 3 часом землеустрій почав пов'язуватися саме із ви рішенням питань, які забезпечують організацію раціонального та ефективного використання земель, підвищенням культури землеробства та охорони земель.

\section{АНАЛІЗ ОСТАННІХ ДОСЛІДЖЕНЬ І ПУБЛІКАЦІЙ}

Серед базових досліджень становлення землеустрою у історичному аспекті та підходів щодо управління земельними ресурсами необхідно визначити, передусім праці А. Чендлера [1, с. 463] та I. Ансоффа [2, с. 519]. Окремі ас- 
пекти стратегічного планування та управління аналізувалися та розроблялися К. Ендрюсом [3, c. 132]. Вітчизняний дослідник Гуцуляк А. характеризує земельні ресурси як одну з баз розвитку та розміщення народного господарства. Саме народного господарства, що надає пріоритетність системі землеустрою у загальному господарюванні держави [4, с. 52].

\section{ПОСТАНОВКА ЗАВДАННЯ}

Земля як основний засіб реалізації земельних відносин набуває значення основного фактору розвитку та надає переважного статусу своєму власнику в будь-якому суспільстві, за будь-яких умов чи періоду суспільного розвитку. Незалежно від історичного розвитку господарських форм суспільства, способи виробництва підпорядковуються саме земельним відносинам, а саме, тим їх формам, які окресленні та продиктовані відповідним змістом землеустрою. Тобто саме землеустрій скеровує способи використання наявних земельних ресурсів, їх регулювання у чітку і збалансовану систему заходів щодо організації управління та охорони земель. Основна суть землеустрою крізь призму історичних змін це його тісний взаємозв'язок з усіма складовими економічних відносин характерних для певного періоду суспільно-історичного розвитку, якому притаманна постійна боротьба за пріоритетний засіб виробництва, зокрема за земельні ресурси. Тому існує потреба у окресленні тенденцій змін у прив'язці до еволюції суспільного способу виробництва за участі землеустрою як його основної складової, що охоплює організацію землі як засобу виробництва.

\section{ВИКЛАД ОСНОВНОГО МАТЕРІАЛУ ДОСЛІДЖЕННЯ}

Історія землеустрою України бере свої витоки ще з давніх часів. Відомо, що першими державницькими відносинами стало об'єднання земель Руської держави Володимиром, Ярославом та іншими князями Київської Русі. Нестор Мітописець описував реформи Володимира так: "Він поважав своє військо і по всім важливим питанням, як то війна і закони, радився з ним". Ці закони називаються "Устав Земляний" [5, c. 253]. Завдяки йому було зміцнено владу феодалів, сприяло становленню та зміцненню дідичного господарства на княжих землях. Та найголовнішим стало те, що саме ця низка законодавчих документів стали правовою основою для створення "Руської Правди" князя Ярослава Мудрого.
За тих часів, територія тодішньої України поділялась на землі та волості. Волості - це алміністративно-територіальна одиниця у Київській Русі, підпорядкована владі одного князя, що входила до складу повіту [6, с. 662]. Вони входили до складу земель. Території були княжими і народними. Київська Русь була утворена завдяки об'єднанню земель удільних князівств та була феодальною державою 3 князівськодружинним устроєм. У середині XII ст. Київська Русь була поділена на частини: Київське, Галицьке, Волинське, Смоленське, Переяславське, Володимиро-Суздальське князівства. А вони у свою чергу поділялися на менші князівства або волості.

XVI ст. на українських землях відбулись докорінні зміни в землекористуванні селян. Їхню землю поділили на державну та панську. Це закріпилось у III Статуті Великого князівства Иитовського - основному кодексі права Великого князівства Аитовського, Руського, Жемайтійського. Згадані зміни у землеустрої запроваджувалась за допомогою "Уставу на волоки", який видали в 1557 році. Завдяки цьому землі переміряли та поділяли на волоки, а от під фільварки віддавали найкращі землі. Фільварки - це земельні угіддя, на яких феодал-поміщик вів власне господарство [7, с. 421]. Селянам віддавали неродючі землі, ділянки на схилах та покинуті території під ведення господарства. Після затвердження унії життя селян ще більше погіршилось, тому що селян будь-яким способами намагались позбавити права на земельні ділянки. Наприклад, селян заставляли понаднормово працювати на панських землях і вони втрачали можливість займатися своїми земельними ділянками. Також селяни залишились без права переходу від одного пана до іншого. В Галичині вони були позбавлені цього права ще в XV ст., на інших землях Аитовсько-Руської держави - в XVI ст., таким чином селяни все життя могли працювати на одного пана. В другій половині XVI ст. польський та литовський уряд затвердили закони, завдяки яким селянам заборонялось переходити на інше місце без згоди його власника. А от за допомогою "Артикули", яку запровадив Генріх Валуа 20 травня 1573 р. на виборчому сеймі Речі Посполитої, затвердили необмежену панщину у маєтках. Велике князівство Аитовське було досить розвинене у галузі права. Можна сказати, що більшість затверджених принципів з Великого князівства Аитовського після Аюблінської унії, яку прийняли 1 липня 1569 року, стали використовувати і в майбутньому. Проте, III Статут, який затвердили у 
1588 році, став найголовнішим джерелом регулювання та становлення земельного права і земельних відносин.

Протягом другої половини XVI ст. до першої половини XVII ст. відбувалось покозачен-

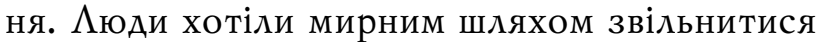
від панщини та отримати право вільно працювати на власній землі. Отже, з появою козаків з'явилась інша система землеустрою. Правові норми земельного регулювання, що склалися на Запорізькій Січі, допомагали підтримувати порядок у користуванні землею та ухваленні різного типу договорів.

У XVII ст. Московське царство провело ревізію українських земель, а у XVI - запровадило Генеральне межування територій на основі проведеної ревізії. Також уряд Катерини II видав Маніфест про розмежування приватних земель (1765р.), а згодом видали "Генеральні правила" і "Настанови землемірам" в 1766 р. Ці акти, більш ніж ціле століття, мали важливу роль у регулюванні земельних відносин та кадастру.

Політика закріпачення, яка проводилась Московським царством та Річчю Посполитою, спонукала селян втікати від переслідування на вільні землі, які були належали до територій земель Запорізької Січі. Подібні земельні відносини були запроваджені Катериною II, яка поширила дію російського законодавства на ці вільні козацькі території.

У XIX ст. земельні відносини змінились. Згідно з указом від 12 грудня 1801 р.: "...міщанам, купцям і всім селянам (звісно, крім поміщиків), було надано право купляти землі", а Селянською реформою від 3 березня 1848 р. це право надали також поміщикам. Завдяки Указу від 20.02.1803 р. "Про вільних хліборобів" поміщикам дозволили відпускати селян на волю за певну плату (викуп), який встановлювався ними ж [8, с. 668].

Відомо, що до 60-років XIX ст., панівною формою господарювання було кріпосницьке господарство, а домінуючою формою управління - клас поміщиків, дворян. Правлячі імператорські особи роздавали землю вельможним людям у власність як "помісні наділи". Маніфест "Про звільнення селян" від 19.02.1861 р. і Положення "Про селян, що звільнились від кріпосної справи", наголосило, що селяни можуть звільнитися від цієї залежності за викуп. Проте за користування землею селяни мали відбувати повинності або їх компенсувати матеріальною Положенням від 19.02.1861р. встановлювалось, що селяни, які звільнились від кріпацтва, мусили об'єднуватись в сільські гро- мади [9, с. 518]. Постановою № 313 ЦК КПУ і Ради Міністрів України від 26.07.1983р. основні положення реформи поширились на удільних селян, а законом від 18.01.1866 р. ще й на державних селян. [10, с. 688]. По положенню від 26.07.1863 р. всіх удільних селян переводили до класу селян-власників. [9, с. 518]. Положення про викуп від 1861 р. наділило членів сільської громади права покинути її при умові дострокового викупу землі. Законом від 14.02.1893 р. право окремих господарів вимагати виділу скасувалось, узгодження про вихід узгоджувалось 3 громадою [11, с. 392]. У Правобережній Україні на той час ввели обов'язковий викуп селянами наділів. На відміну від них, селяни $\Lambda$ івобережжя та Півдня, перевелись на обов'язковий викуп лише у 1886 році. В результаті реформ на Правобережжі, на Півдні та Полтавщині майже вся земля селян перейшла у приватну власність поміщиків.

Після Російської революції у 1905 р. земельна політика на українських землях зазнала великих змін, що знайшла відображення в законах та інших актах, внаслідок чого уряд вирішив створити надійний форпост в обличчі багатого селянства. У 9.11.1905 р. був виданий царський маніфест "Про поліпшення добробуту і полегшення становища селянського населення". Згідно з цим документом, викупні платежі урізались наполовину 3 1906 р., а з 1907 р. скасовувались повністю. 3 цього часу на земельні відносини значний вплив справила Столипінська аграрна реформа, розробником якого був російський державний діяч - П.А. Столипін. Було прийнято укази "Про зменшення і наступне припинення всіх платежів з селян" та "Про полегшення завдань Селянського Поземельного банку по сприянню у збільшенні площі землеволодіння малоземельних селян", останній ввів кредитування для погашення заборгованості селян коштом викупних платежів, що надійшли до банку. В серпні 1906 р. видано указ "Про призначення казенних земель до продажу для розширення селянського землекористування", який почав готувати державу до радикальних реформ землеволодіння [12, с. 24-26]. У вересні того ж року було видано "Про передачу кабінетних земель в розпорядження Головного управління землеробства та землевпорядкування з метою утворення селянських ланок", який регламентував початок переселення селян із займаних територій [13, с. 68-69].

У 1906 році прийняли указ "Про відміну деяких обмежень у правах сільських обива- 
телів та осіб інших бувших податних слоїв". В ньому вказали єдині права для всіх громадян стосовно державної служби "окрім іногородців". Відмінювався податок щодо обов'язкового виключення селян 3 сільського товариства в разі вступу на цивільну службу, отримання орденів, вчених ступенів, закінченні навчання в закладах освіти, призначенні на посади. Селяни могли самі обирати місце проживання. Його визначали за місцем знаходження власності або служби. Волосні органи видавали паспорти по місцю прописки, а поліція - по місцю знаходження власності. Також відмінили підкореність земським начальникам та накладення адміністративних стягнень [14, с. 859].

Столипінський указ від 09.11.1906 р. затверджував вільний порядок виходу з общини та фіксування наділів у селянську власність у будь-який час. Будь-який господар мав право вимагати фіксування наділу землі у приватну власність і виділення 3 общини навіть тоді, коли його розмір перевищував норму, яка встановлювалась на частку двору в конкретній сільській громаді на момент виділення [15, с. 273].

Акт "Про видачу Селянським Поземельним банком позичок під заставу надільних земель", який прийняли в листопаді 1906 року, забезпечував фінансування реформи. В зв'язку 3 цим, відмінялась заборона віддавати під заставу приватним особам та товариствам надільні землі. Основні положення від 9.11.1906 р. закріпились і розвивались від 14.06.1910 р. [16, с. 273].

Завдяки встановленню приватної власності на землю, заможні селяни отримали можливість скуповувати землі бідніших селян і, таким чином, посилити концентрацію надільної селянської землі. Значна частина надільної землі перейшла до багатих селян на підставі договорів про оренду землі. Згідно з указом від 4.03.1906 р. створили систему землевпорядних органів, яка стала головною ланкою в земельній політиці царського уряду. Прийнятий в 29 травня 1911 року Закон "Про землеустрій" детально регламентував порядок землеустрою. Орендарі землі не мали права заперечувати проти їх розверстування [17, с. 388-407]. Закон "Про Землеустрій", який був прийнятий 29.05.1911 p. розгорнуто регламентував порядок землеустрою. Орендарі не мали жодного права суперечити розверстуванню. Затверджено порядок, за яким створювали комісії із землеустрою під керівництвом головних представників дворянства. Земські начальники мали вести збори, які вирішували питання про розверстування земель. Всі суперечки вирішували в уїздній комісії. Всі рішення могли оскаржити в Сенаті $[18$, c. 343].

Виникнення в Росії різних форм власності, володіння і користування землею призвело до створення особливої правової галузі - земельного права. Після перемоги Жовтневої революції, в законодавстві України відбулись великі зміни. Аекрет "Про землю", прийнятий 26.10.1917 року, став тим земельним законодавчим документом СРСР, що назавжди скасував право приватної власності на землю. Він був затверджений в СРСР рішенням Першого Всеукраїнського з'їзду Рад від 12.12.1917 року [19, с. 319]. Він зобов'язував встановити повну координацію у своїх цілях і діях з Росією та іншими частинами Союзу. 3'їд доручив обраній ним ЦВК України поширити на території України всі декрети та розпорядження Робітничо-Селянського Уряду, що мали важливе значення для всієї держави. Аекрет був заснований на "селянському Аекреті про землю", який став обов'язковою частиною Аекрету "про землю". У зв'язку з цим указом вся земля була націоналізована і передана волосним земельним комітетам і повітовим радам селянських депутатів. Землю не забирали лише у рядових селян і козаків [20, с. 205].

Аекрет РНК РРФСР "Про соціалізацію землі" від 19.02.1918 року скасував приватну власність на землю і передав її робочим для вирівнювання землекористування. Маніфестом Тимчасового робітничо-селянського уряду в 1919 році Україна оголосила, що землі поміщицьких прохань повинні бути відібрані і передані селянам. Це було прописано в Конституції Української РСР, а також у постанові РНК Української РСР від 3.04.1920 року [21, с. 268].

Оновлена політика уряду Радянського Союзу вимагала чіткого затвердження земельного законодавства. Так почалося видання земельних кодексів всіх республік СРСР. Першою республікою, яка вийшла в світ, була РРФСР. Земельний кодекс створив основні передумови для формування земельного права в Союзі.

Аосвід Російської соціалістичної республіки щодо генералізації земельного законодавства використовувався й іншими республіками СРСР. 29.11.1922 року третя сесія ВУЦВК 6 скликання прийняла Земельний кодекс СРСР. Він став головною ланкою при створенні земельного законодавства в УРСР. Загалом земельні кодекси всіх республік майже ідентичні. Пер- 
ший Земельний кодекс СРСР скасував приватну власність на землю, продаж, оренду та інші відносини, що пов'язані з відчуженням землі. Також затверджено націоналізацію землі. Право отримати землю в безоплатне і необмежене користування закріплювалось за усіма громадянами незалежно від їхньої статі, віри та національності. 3КУ затвердили постановою 7 Всеукраїнського з'їзду рад від 14.12.1922 року, а резолюція просила селян перейти до більш доскональних форм користування землею. Важливим документом цього періоду була постанова ВРУ та РНК від 18.07.1928 року "Про вилучення та відведення земель для державних і суспільних потреб" [22, с. 62]. Постановою ЦВК і РНК СРСР від 16.03.1927 року "Про колективні господарства" проголошувалося припинення землевпорядкування на землях колгоспу, передачу колгоспам у користування землі із держфонду, надання їм пільг. 3 цього часу земельні фонди всіх республік перетворились в єАиний земельний фонд СРСР, який став єдиним суб'єктом викдючного права державної власності на землю.

01.03.1930 року було прийнято постанову РНК СРСР і Президії ЦВК СРСР "Про затверАження зразкового статуту сільськогосподарської артілі", в якому були знищені всі кордони, що розділяли наділи членів кооперативів $[23$, с. 9]. 25 лютого 1930 року вийшла постанова "Про скасування земельних громад у районах суцільної колективізації", а також у селах, де велика частина бідного населення охоплена виробництвом сільськогосподарської кооперації. У зв'язку з цією постановою функції регулювання землекористування перейшли до колгоспів. Постанова Центральної Виборчої Комісії та РНК Радянського Союзу "Про заборону здачі в оренду земель с/г призначення" забороняла оренду земельних ділянок на державному рівні. Це означало те, що господарі мали право володіти та користуватися лише своєю землею.

Земельний кодекс Української РСР прийняли 08.07.1970 р. Стаття 3 Земельного кодексу УРСР підкреслила, що відповідно до Конституції Радянського Союзу і цієї республіки, земля є державною і може надаватися лише в користування. Основні закони Союзу та республік про землю прийняли 28.02.1990 року [24, c. 672]. Аекларація про державний суверенітет України проголосила верховенство Конституції та законів кожної республіки на своїх територіях, а також самостійність в економічних аспектах та законодавстві. Однак у декларації не було ні слова про чинність на території УРСР законів Союзу. Після розпаду Радянського Союзу Україна стала самостійною державою. Виникло багато питань, які треба було терміново вирішувати. Наприклад, якщо Радянський Союз звик до певного зведення законів, колишня республіка мала встановити своє земельне законодавство. Все почалось з ініціативи створення інституту приватної власності. Фактично, за часів СРСР була лише державна власність на землю, тож запропонована земельна реформа мала змінити як систему ведення землеустрою України, так і ввести певні корективи в законодавство.

У 1992 році, після ухвалення Земельного кодексу України, розпочалися реформи землі. Першим і найголовнішим етапом стало розпаювання території. Ці землю ділили на земельні частки. Члени підприємств отримували сертифікати єдиного зразка. Вони гарантували право на земельну частку, тобто пай. Також власники сертифікатів могли покинути підприємство, проте залишитися зі своїми земельними частками та виділити їх на місцевості. Ао 2000 року завершився перший етап земельної реформи. Наслідком стало те, що понад 6000000 селян отримали сертифікати на виділення паїв у приватну власність [25].

Новим етапом стало реформування колективних сільськогосподарських підприємств. На думку аграріїв, ця форма господарювання була прототипом колгоспу, тож не могла відповідати новим вимогам. Міжнародний валютний фонд активно надавав поради Україні щодо приватизації землі, тому необхідно було реформувати землю в господарські структури на приватній власності. Власники паїв почали отримувати ділянки реформованих колективних сільськогосподарських підприємств у натурі та оформлювати державні акти на право власності на землю. Це тривало аж до кінця 2000-х років. Ао Аержземкадастру земельні ділянки продовжують вносити до сьогодні.

Переломним моментом в землеустрої України стало запровадження мораторію на продаж землі в березні 1992 року. Це було реалізовано в новій редакції Земельного кодексу України [26, с. 5-15]. У результаті 15-річноїдії мораторію основна форма земельних відносин в Україні - це орендні договори з пайовиками. Ринок оренди характеризується локальними монополіями, бо навіть якщо на території умовних сільради/району землю обробляють кілька орендарів, то їхні цінові пропозиції, як правило, ідентичні [27, с. 89-90]. 
Відомо, що близько $96 \%$ сільськогосподарських земель підпадають під дію мораторію, $68 \%$ земель знаходиться у власності селян-пайовиків. Не секрет, що українській земельній реформі, фундаменту земельного законодавства - 28 років. Це світовий рекорд. Ао цього першість тримала Мексика [28]. Позитивними наслідками, на нашу думку, зняття мораторію на продаж землі, стала б для власників земельних ділянок сільськогосподарського призначення, які самостійно її не обробляють, можливість продати іншій юридичній особі. Також для землекористувачів, відносними плюсами дії мораторію, є користування земельними активами за низькою ціною, а також направлення вільних коштів на оновлення технічного парку, інфраструктури, придбання насіння, добрив, засобів захисту рослин тощо. Аля суб'єктів розпорядження державними та комунальними землями сільськогосподарського призначення перевагою дії мораторію є можливість незаконної передачі земель у користування та привласнення коштів.

Відтак розглянемо всі мінуси впровадження вільного продажу землі. За рахунок продажу землі селян місцеві поповнюватимуться в будь-якому випадку й розширюватимуться. Земля буде переходити з одних рук в інші. Можливо це буде інвестор - вітчизняний, або іноземний. Українські фермери не мають змоги скуповувати землі через обмеженість у фінансах. Тому, скоріш за все, паями володітимуть іноземці. Важливим фактором $є$ також контроль за тим, чи використовується земля за цільовим призначенням. Іншою ланкою створення земельної біржі, яка б слідкувала за тим, як земля переходить від одного власника до іншого. Аише при затвердженні всіх необхідних законів Україна зможе відкрити ринок землі. Нині наше законодавство не готове для таких рішучих змін.

\section{вИСНОВКИ}

В Україні при організації сучасного типу землеустрою доцільно було б звернутися до світового досвіду країн із цивільною ринковою економікою, в тому числі й стосовно ринку сільськогосподарських земель. Більшість держав з так званим вільним оборотом земель вже давно запровадили дозвільну систему на відчуження сільськогосподарських земель, що знімає переважну частку недоліків у систему землевпорядкування. Результатом такого запозичення досвіду могло б бути те, що у процесі перерозподілу земель потрібно формувати такий ринок землі, який би був контрольованим з боку суб'єктів земельних відносин та відносно жорстко обмеженим з боку держави, i, з одночасним дотриманням вільного обігу земель серед учасників земельного ринку. Тому кожна реформа має бути законодавчо обгрунтованою. Насамперед найголовнішим кроком сучасного керівництва держави є донесення до народу вірогідної інформації щодо зняття мораторію на продаж землі та всі подальші кроки земельної реформи. На нашу думку, найважливішою задачею на шляху формування сталих земельних відносин в Україні $є$ розроблення законопроєкту про внесення змін і доповнень до Закону України "Про землеустрій" та інших законодавчих актів щодо закріплення правових підстав проведення землеустрою, вилучення декларативних та непрацюючих правових положень, об'єднання та спрощення землевпорядних процедур, запровадження саморегулювання у сфері землеустрою.

\section{$\Lambda$ ітература:}

1. Chendler A. D. Strategy and strukture. Cambridge: chapters in the history of the industrial enterprise: MIT Press, 1962. $463 \mathrm{p}$.

2. Ансофф И. Стратегическое управление. Москва: Экономика, 1989.519 с.

3. Andreus K. The Consept of the Corporate Strategy. 3rd. Ed. Homewood III: Richasd D., $1987.132 \mathrm{p}$.

4. Гуцуляк Г.А. Земельно-ресурсний потенціал Карпатського регіону. Аьвів: Світ, 1991. 152 с.

5. Боряк Г.В., Верстюк В.Ф. Енциклопедія історії України: в 10 т. / ред. В.А. Смолій. Київ: Наук. думка, 2013. Т.10. 253 с.

6. Юридична енциклопедія / редкол.: Ю.С. Шемшученко та ін. Київ: Українська енциклопедія, 1998. Т. 1.662 с.

7. Смолій В., Кульчицький С., Майборода О. Малий словник історії України. Київ: Аибідь, 1997.457 c.

8. Аазанська T.I. Енциклопедія історії України: в 11 т. Київ: Наук. думка, 2003. Т. 1: Вільні хлібороби. $688 \mathrm{c}$.

9. Аазанська T.I. Енциклопедія історії УКраїни: в 11 т. Київ: Наук. думка, 2012. Т. 9: Селянська реформа $1861.518 \mathrm{c}$.

10. Юридична енциклопедія / редкол.: Ю.С. Шемшученко та ін. Київ: Українська енциклопедія. 2003. Т. 5.392 с.

11. Бєлая О., Распутіна $\Lambda$. Погляд крізь століття. Землевпорядники та Столипінська реформа. Землевпорядний Вісник. 2018. № 1. C. 24-26. 
12. Кульчицький В., Настюк М., Тишик Б. Історія держави і права України. Київ: Юрінком Інтер, 1999, С. 68-69.

13. Волковинський В.М., Хоптяр Ю.А. Столипінська аграрна реформа. Київ: Наук. думка, 2012. 859 с.

14. Музиченко П.П. Історія держави і права України. Київ: Знання, 2000, 273 с.

15. Аісова Т.В. Законодавство про землеустрій: становлення та його розвиток, 2004. URL: https://lawbook.online/pravo-ukrajinizemelne/zakono davstvo-pro-zemleustriystanovlennya-61797.html (дата звернення: 22.09.2021).

16. Кулинич П., Медведєв К., Потапенко А., Тиханський О., Семенюк В. Становлення і розвиток земельного законодавства України у XX - на початку XXI століття. Київ: ФОП Клименко Ю.Я., 2018, 142 с.

17. Реєнт О.П., Сердюк О.В. Столипінська аграрна реформа: в 2 т./ відп. ред. В.А. Смолій. К.: Наукова думка, 2006. Т. 1: Історія українського селянства. С. 388-407.

18. Хміль I.В. Енциклопедія історії України: в 9 т. / відп. ред. В.А. Смолій. К.: Наукова думка, 2004. Т. 2: Аекрет про землю 1917. C. 319 .

19. Капелюшний В.П. Енциклопедія сучасної України: в 7 т. Київ: Інститут енцикл. досліджень НАН України, 2005. Т. 4: Аекрети радянської влади. 205 с.

20.Кульчицький С.В.Енциклопедія історії України: в 4 т. Київ: Наук. думка, 2005. Т. 3: Закон про соціалізацію землі 1918. $268 \mathrm{c}$.

21. Верт Н. Історія радянської держави. Москва: ВПА, 1995. 347 с.

22. Кульчицький С.В. Ендиклопедія історії України: в 12 т. Київ: Наук. думка, 2009. Т. 9: Примірні статути сільськогосподарської артілі. C. 9-12.

23. Кулинич П.Ф. Енциклопедія історії України: в 5 т. / відп. ред. В.А. Смолій. К.: Наукова думка, 2005. Т. 3: Земельні кодекси УСРРУРСР. $672 \mathrm{c}$.

24. Самойленко А. Право власності на землю: процес отримання документів. 2012. URL:/ /www.npp.com.ua/articles/articles/2567.html (дата звернення: 21.09.2021).

25. Аупенко Ю.О., Ходаківська О.В. Наукові засади запровадження ринкового обігу земель сільськогосподарського призначення. Економіка АПК. 2016. Вип. 12. С. 5-15.

26. Удовенко I.O. Місце земельної ділянки сільськогосподарського призначення в економіці України. II International Confe- rence of European Academy of Science on the topic. Bonn, Germany. 20-28 November. 2018. P. 89-90.

27. Як проходить мораторій на продаж землі. Український земельний ринок. 2021. URL: //land-ukraine.com/news/yak_obkhodyat_moratorii_na_prodazh_zemli/(дата звернення: 23.09.2021).

\section{References:}

1. Chendler, A.D. (1962), Strategy and strukture, MIT Press, London, UK.

2. Ansoff, I. (1989), Strategicheskoe upravlenie [Strategic management], Ekonomyka, Moscow, Russia.

3. Andrews, K. R. (1987), The Concept of Corporate Strategy, 3rd ed, Homewood, IL: R.D. Irwin, UK.

4. Gutsulyak, G.D. (1991), Zemel'no-resursnyy potentsial Karpats'koho rehionu [The Land resource potential of the Carpathian region], Svit, Lviv, Ukraine.

5. Boriak, H.V. and Verstiuk, V.F. (2013), Entsyklopediia istorii Ukrainy [Encyclopedia of the History of Ukraine], Naukova dumka, Kyiv, Ukraine.

6. Shemshuchenko, Yu.S. (1998), Yurydychna entsyklopediia [Legal Encyclopedia], Ukrains'ka entsyklopediia, Kyiv, Ukraine.

7. Smolij, V., Kul'chyts'kyj, S. and Majboroda, O. (1997), Malyj slovnyk istorii Ukrainy [Small dictionary of Ukrainian history], Lybid', Kyiv, Ukraine.

8. Lazans'ka, T.I. (2003), Entsyklopediia istorii Ukrainy: Vil'ni khliboroby [Encyclopedia of the History of Ukraine: Free farmers], Naukova dumka, Kyiv, Ukraine.

9. Lazans'ka, T.I. (2012), Entsyklopediia istorii Ukrainy: Selians'ka reforma 1861 [Encyclopedia of the History of Ukraine: Peasant reform 1861], Naukova dumka, Kyiv, Ukraine.

10. Shemshuchenko, Yu.S. (2003), Yurydychna entsyklopediia [Legal Encyclopedia], Ukrains'ka entsyklopediia, Kyiv, Ukraine.

11. Bielaia, O. and Rasputina, L. (2018), "A look through the centuries. Land managers and the Stolypin reform", Zemlevporiadnyj Visnyk, vol. 1, pp. 24-26.

12. Kul'chyts'kyj, V., Nastiuk, M. and Tyshyk, B. (1999), Istoriia derzhavy i prava Ukrainy [History of State and Law of Ukraine], Yurinkom Inter, Kyiv, Ukraine.

13. Volkovyns'kyj, V.M. and Khoptiar, Yu. A. (2012), Stolypins'ka ahrarna reforma [Stolypin agrarian reform], Naukova dumka, Kyiv, Ukraine. 
14. Muzychenko, P.P. (2000), Istoriia derzhavy i prava Ukrainy [History of the state and law of Ukraine], Znannia, Kyiv, Ukraine.

15. Lisova, T.V. (2004), "Legislation on land management: formation and its development", available at: https://lawbook.online/pravoukrajini-zemelne/zakonodavstvo-pro-zemleustriy-stanovlennya-61797.html (Accessed 22 September 2021).

16. Kulynych, P., Medvediev, K., Potapenko, A., Tykhans'kyj, O. and Semeniuk, V. (2018), Stanovlennia i rozvytok zemel'noho zakonodavstva Ukrainy u KhKh - na pochatku KhKhI stolittia [Formation and development of land legislation of Ukraine in the XX - early XXI], FOP Klymenko Yu.Ya., Kyiv, Ukraine.

17. Reient, O.P. and Serdiuk, O.V. (2006), Stolypins'ka ahrarna reforma: Istoriia ukrains'koho selianstva [Stolypin's agrarian reform: History of the Ukrainian peasantry], Naukova dumka, Kyiv, Ukraine.

18. Khmil', I.V. (2004), Entsyklopediia istorii Ukrainy: Dekret pro zemliu 1917 [Encyclopedia of the History of Ukraine: Decree on Land 1917], Naukova dumka, Kyiv, Ukraine.

19. Kapeliushnyj, V.P. (2005), Entsyklopediia suchasnoi Ukrainy: Dekrety radians'koi vlady [Encyclopedia of modern Ukraine: Decrees of the Soviet government], Instytut entsykl. doslidzhen' NAN Ukrainy, Kyiv, Ukraine.

20. Kul'chyts'kyj, S.V. (2005), Entsyklopediia istorii Ukrainy: Zakon pro sotsializatsiiu zemli 1918 [Encyclopedia of the History of Ukraine: Law on Socialization of Land 1918], Naukova dumka, Kyiv, Ukraine.

21. Wert, N. (1995), Istoriia radians'koi derzhavy [History of the Soviet state], VPA, Moscow, Russia.

22. Kul'chyts'kyj, S.V. (2009), Endyklopediia istorii Ukrainy: Prymirni statuty sil's'kohospodars'koi artili [Encyclopedia of the History of Ukraine: Exemplary statutes of the agricultural artel], Naukova dumka, Kyiv, Ukraine.

23. Kulynych, P.F. (2005), Entsyklopediia istorii Ukrainy: Zemel'ni kodeksy USRR-URSR [Encyclopedia of the History of Ukraine: Land Codes of the USSR-USSR], Naukova dumka, Kyiv, Ukraine.

24. Samojlenko, A. (2012), Pravo vlasnosti na zemliu: protses otrymannia dokumentiv [Land ownership: the process of obtaining documents], available at: //www.npp.com.ua/articles/ articles/2567.html (Accessed 21 September 2021).

25. Lupenko, Yu.O. and Khodakivs'ka O.V. (2016), "Scientific principles of introduction of market circulation of agricultural lands", Ekonomika APK, vol. 12, pp. 5-15.

26. Udovenko, I.O. (2018), "The place of the agricultural land in the economy of Ukraine", Conference Proceedings of the International Conference [II International Conference of European Academy of Science on the topic], Bonn, Germany, 20-28 November, pp. 89-90.

27. Land-Ukraine (2021), "Land market. How is the moratorium on land sales", available at:// land-ukraine.com/news/yak_obkhodyat_moratorii_na_prodazh_zemli/(Accessed 23 September 2021).

Стаття надійшла до редакчї 25.09.2021 p.

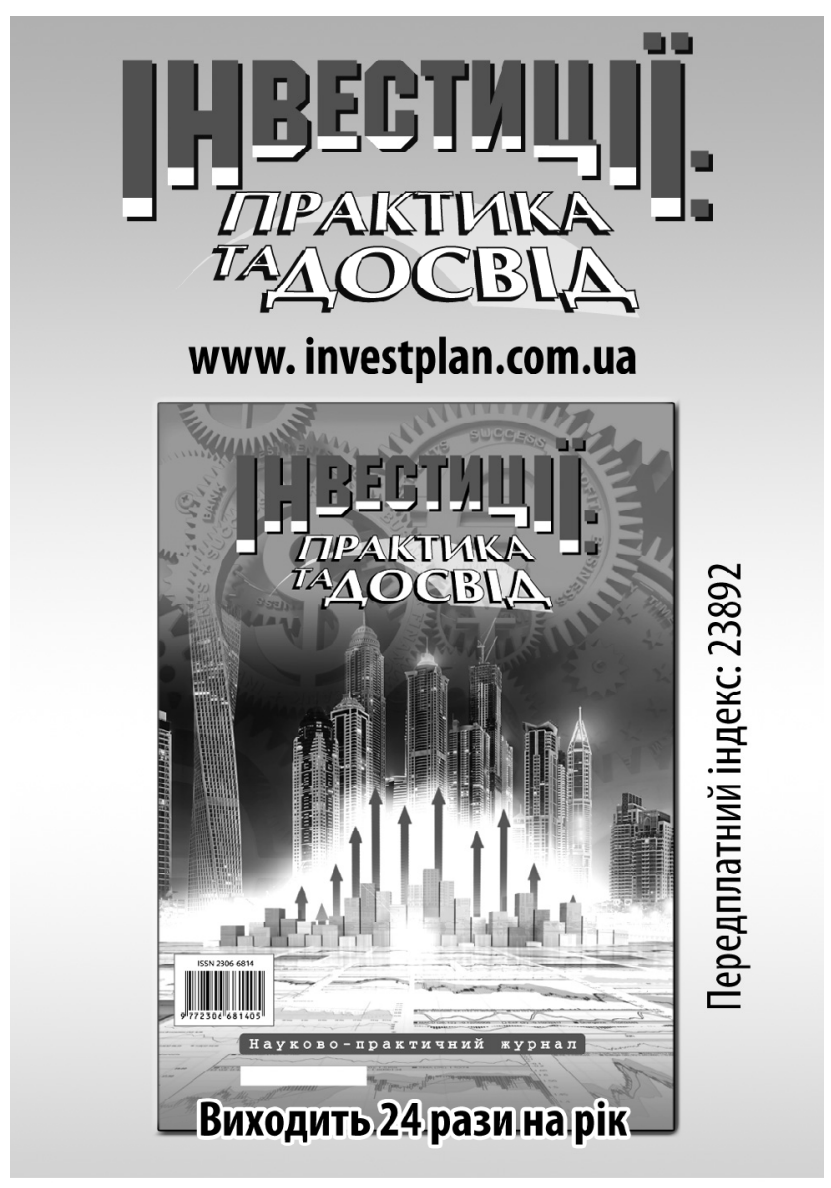

Журнал включено до переліку наукових фрахових видань України (Категорія «Б») 3

ЕКОНОМІЧНИХ НАУК та ДЕРЖАВНОГО УПРАВЛІННЯ

(Наказ Міністерства освіти і науки України № 886 від 02.07.2020)

Спеціальності - 051, 071, 072, 073, 075, 076, 281, 292 
УAK 330.322:631:132.2
В. М. Ходаківський,
к. е. н., Аоцент, Аоцент кафеАри економіки і підприємництва,
Поліський національний університет, м. Житомир
ORCID ID: 0000-0003-3913-7461
Г. Ю. Максимович,
магістрант кафедри економіки і підприємництва,
Поліський національний університет, м. Житомир
ORCID ID: 0000-0002-5772-1189
$\Lambda$. M. Садурська,
магістрант кафедри економіки і підприємництва,
Поліський національний університет, м. Житомир
ORCID ID: 0000-0001-9407-5414
T. П. Чайківська,
магістрант кафедри економіки і підприємництва,
Поліський національний університет, м. Житомир
ORCID ID: 0000-0002-6845-8435

DOI: $10.32702 / 2306-6792.2021 .19 .50$

\title{
СУЧАСНІ УМОВИ ТА ААЬТЕРНАТИВИ РОЗВИТКУ ІНВЕСТИЦІЙНОГО ЗАБЕЗПЕЧЕННЯ СІАЬСЬКОГОСПОААРСЬКИХ ПІАПРИЄМСТВ ЖИТОМИРСЬКОЇ ОБААСТІ
}

\author{
V. Khodakyvskyy, \\ $\mathrm{PhD}$ in Economics, Associate Professor, Associate Professor of the Department \\ of Economics and Entrepreneurship, Polissya National University, Zhytomyr \\ G. Maksimovich, \\ Master's student of the Department of Economics and Entrepreneurship, Polissya National University, Zhytomyr \\ L. Sadurska, \\ Master's student of the Department of Economics and Entrepreneurship, Polissya National University, Zhytomyr \\ T. Tchaikivska, \\ Master's student of the Department of Economics and Entrepreneurship, Polissya National University, Zhytomyr
}

\section{MODERN CONDITIONS AND ALTERNATIVES FOR THE DEVELOPMENT OF INVESTMENT SUPPORT OF AGRICULTURAL ENTERPRISES OF ZHYTOMYR REGION}

Проаналізовано сучасний стан інвестиційного забезпечення сільськогосподарських підприємств Житомирської області. Запропоновано зміни щодо існуючої структури інвестування сільськогосподарських підприємств та ії докорінної перебудови відносно реалізованої стратегії децентралізації. Встановлено взаємозв'язок між кількісними та якісними параметрами інвестування у відношенні до ефективності діяльності сільськогосподарських підприємств та масштабами їх виробництва. Надано рекомендації щодо поліпшення існуючих умов інвестиційного забезпечення сільськогосподарських підприємств Житомирської області. Аосліджено та структуровано джерела інвестиційного забезпечення сільськогосподарських підприємств та проведено їх якісну оцінку в порівнянні 3 прогресивними економічними системами високорозвинутих країн світу. Виявлено недостатність покриття інвестиційних потреб сільськогосподарських підприємств у календарному господарському періоді та доведено її негативний вплив на умови ефек- 
тивності господарської діяльності сільськогосподарських підприємств. Надано рекомендації щодо актуалізації умов якісного поліпшення інвестування сільськогосподарських підприємств з врахуванням умов іх сталого розвитку як невід'ємної складової їх функціонування в стратегічній перспективі та набуття можливих конкурентних переваг.

The current state of investment support of agricultural enterprises of Zhytomyr region is analyzed. Changes in the existing structure of investment of agricultural enterprises and its radical restructuring of the implemented decentralization strategy are proposed. The relationship between quantitative and qualitative parameters of investment in relation to the efficiency of agricultural enterprises and the scale of their production. Recommendations for improving the existing conditions of investment support of agricultural enterprises in Zhytomyr region are given. The sources of investment support of agricultural enterprises are researched and structured and their qualitative assessment is carried out. Insufficient coverage of investment needs of agricultural enterprises in the calendar economic period is revealed and its negative impact on the conditions of efficiency of economic activity of agricultural enterprises is proved. Recommendations for updating the conditions for qualitative improvement of investment of agricultural enterprises, taking into account the conditions of their sustainable development as an integral part of their operation in the strategic perspective. The indicators of efficiency of agricultural enterprises of Zhytomyr region in relation to the size and scale of their activity, average production costs, levels of labor productivity, intensity of land use and the number of used investment resources are systematized. The expediency of rational changes in terms of conditions and forms of implementation of regional investment programs in the medium-term economic alternative is substantiated. The need to increase the level of own financial support of agricultural enterprises in certain economic periods in order to cover current investment needs is indicated. The involvement of the processes of organizational and legal regulation of the current system of investment support of agricultural enterprises of Zhytomyr region is indicated. The low level of reinvestment processes due to excessive use of borrowed financial resources by agricultural enterprises has been proved. The high cost of credit borrowings and unfair terms of their repayment in the process of investment support of agricultural enterprises is indicated.

Ключові слова: інвестичійне забезпечення, сільськогосподарські підприємства, регіон, забезпечення, ефективність, діяльність, перспектива, рекомендачії, сучасний стан, джерела інвестування, обгрунтування, масштаби використання, аргументачія.

Key words: investment support, agricultural enterprises, region, provision, efficiency, activity, perspective, recommendations, current state, sources of investment, substantiation, scale of use, argumentation.

\section{ПОСТАНОВКА ПРОБЛЕМИ У ЗАГАЛЬНОМУ ВИГЛЯДІ ТА ІІЇ ЗВ'ЯЗОК ІЗ ВАЖЛИВИМИ НАУКОВИМИ ЧИ ПРАКТИЧНИМИ ЗАВДАННЯМИ}

На сучасному етапі розвитку економіки проблеми зниження інвестиційної привабливості вітчизняних підприємств, ділової активності на інвестиційному ринку України та дестабілізація національної економіки є достатньо актуальними й пріоритетними завданнями для вирішення проблем як на макро-, так і на мікрорівнях та при формуванні державної інвестиційної політики. Необхідність здійснення інвестицій у сільське господарство є об'єктивною через специфіку процесу його виробництва. Обсяг інвестицій у сільське господарство завжди був недостатнім порівняно з потребою. В умовах, що виникли, інвестиційна проблема в сільському господарстві особливо загострилась. Виходячи 3 обмеженості внутрішніх ресурсів сільськогосподарських підприємств України, найпривабливішим джерелом ресурсного забезпечення сільського господарства тут можуть бути іноземні інвестиції. Але бажання іноземного інвестора вкладати кошти в сільськогосподарські підприємства країни формується під впливом багатьох факторів, які не завжди є сприятливими. За таких умов необхідно формувати позитивне інвестиційне середовище з метою підвищення інвестиційної привабливості аграрної сфери [6].

Відносно реалізації умов інвестиційного забезпечення сільськогосподарських підприємств регіону постає низка питань щодо їх ефективного залучення та використання, оскільки проведення процесів децентралізації в 
значній мірі вплинуло на ефективність функціонування даної системи та потребує докорінної її перебудови. Існуючі умови інвестиційного забезпечення сільськогосподарських підприємств у переважній мірі спрямовані на досягнення лише економічного ефекту їх реалізації без врахування перспектив сталого розвитку сільської економіки, що позиціонує цей вид бізнесу лише з позиції використання наявного земельного ресурсу. Крім того, інвестиційне забезпечення сільськогосподарських підприємств Житомирської області містить елементи якісної неповноти 3 позиції відсутності окремих елементів ринку інвестиційних послуг, що в деякій мірі унеможливлює його ефективне функціонування. Ефективно налагоджені процеси змін умов інвестиційного забезпечення сільськогосподарських підприємств здатні значно поліпшити існуючу ситуації та раціоналізувати напрямок її зміни.

\section{АНАЛІЗ ОСТАННІХ ДОСЛІДЖЕНЬ І ПУБЛІКАЦІЙ, В ЯКИХ ЗАПОЧАТКОВАНО РОЗВ'ЯЗАННЯ ДАНОЇ ПРОБЛЕМИ І НА ЯКІ СПИРАЮТЬСЯ АВТОРИ, ВИДІЛЕННЯ НЕ ВИРІШЕНИХ РАНІШЕ ЧАСТИН ЗАГАЛЬНОЇ ПРОБЛЕМИ, КОТРИМ ПРИСВЯЧУЄТЬСЯ ОЗНАЧЕНА СТАТТЯ}

Вивченню умов та процесів інвестиційного забезпечення сільськогосподарських підприємств присвячені дослідження таких вчених: I. Бланка, I. Вінніченка, А. Войнаренка, А. Гайдуцького, О. Гальчинського, О. Гудзинського, О. Гудзя, М.Аем'яненка, Т. Аудара, В. Іванишина, М. Кісіля, М. Коденської, О. Козак, М. Корецького, С. Кравченка, О. Крисального, М. Кропивки, Г. Аайко, Ю. Аупенка, П. Макаренка, М. Маліка та ін. [1].

Проте реалізація умов інвестиційного забезпечення в межах конкретних регіонів потребує більш детального вивчення з позиції стрімкого нарощування темпів реорганізації їх господарського середовища, уніфікації існуючих управлінських структур та перебудови існуючих економічних відносин на якісно новий рівень їх ефективного забезпечення. Специфіка галузі сільськогосподарського виробництва також вносить вагомі корективи в сам процес інвестування та потребує негайних змін відносно перебудови існуючих інвестиційних відносин у довгостроковій господарській альтернативі. Саме тому дослідження питань регіонального інвестиційного забезпечення сільськогосподарських підприємств є досить актуальним та потребує детального вивчення.

\section{ЗАВДАННЯ СТАТТІ}

Завданнями дослідження є: аналіз та якісна оцінка умов інвестиційного забезпечення сільськогосподарських підприємств Житомирської області, виявлення проблем їх ефективного функціонування та якісного залучення і використання як власних так і залучених інвестиційних ресурсів; виокремлення чинників та факторів безумовного впливу на обсяги використання інвестиційних ресурсів сільськогосподарських підприємств та оцінки процесів реінвестування.

Об'єктом дослідження є процес інвестиційного забезпечення сільськогосподарських підприємств Житомирської області та інтеграція його відносин у загальнонаціональну інвестиційну систему як невід'ємного фактора ефективного розвитку в довгостроковій господарській альтернативі.

\section{ВИКЛАД ОСНОВНОГО МАТЕРІАЛУ ДОСЛІДЖЕННЯ 3 ПОВНИМ ОБГРУНТУВАННЯМ ОТРИМАНИХ НАУКОВИХ РЕЗУЛЬТАТІВ}

Сучасні умови інвестиційного забезпечення сільськогосподарських підприємства суттєво відрізняються від існуючих теорій інвестування сформованих в неокласичних наукових школах та вимагають суттєвого їх дослідження 3 причини стрімкого нарощування об'ємів процесу глобалізації в довгостроковій господарській перспективі. Прискоренню типологічним змінам процесів інвестиційного забезпечення сільськогосподарських підприємств сприяють процеси стрімкого зростання вартості господарських ресурсів та формування економічної асиметричності їх проявів внаслідок підвищення рівня та частоти проявів різного роду економічних кризових явищ.

Таким чином, сучасна практика управління інвестиційними процесами у сільському господарстві вимагає розробки системи індикативних показників, побудованих на основі єдиного методологічного підходу, і яка буде придатна до агрегування з метою використання для аналізу інвестиційної діяльності не тільки в розрізі окремих проєктів, а й на рівні підприємства загалом, чи сукупності підприємств на регіональному і загальноекономічному рівнях, що визначає вимоги до складу цих показників. Крім того, вона має максимально відображати найважливіші характеристики інвестування за схемою "Ресурси-Вкладення-Результат", адекватно, гнучко й оперативно реагувати на зміну внутрішніх і зовнішніх факторів, що впливають на інвестиційне забезпечення, нести інформа- 


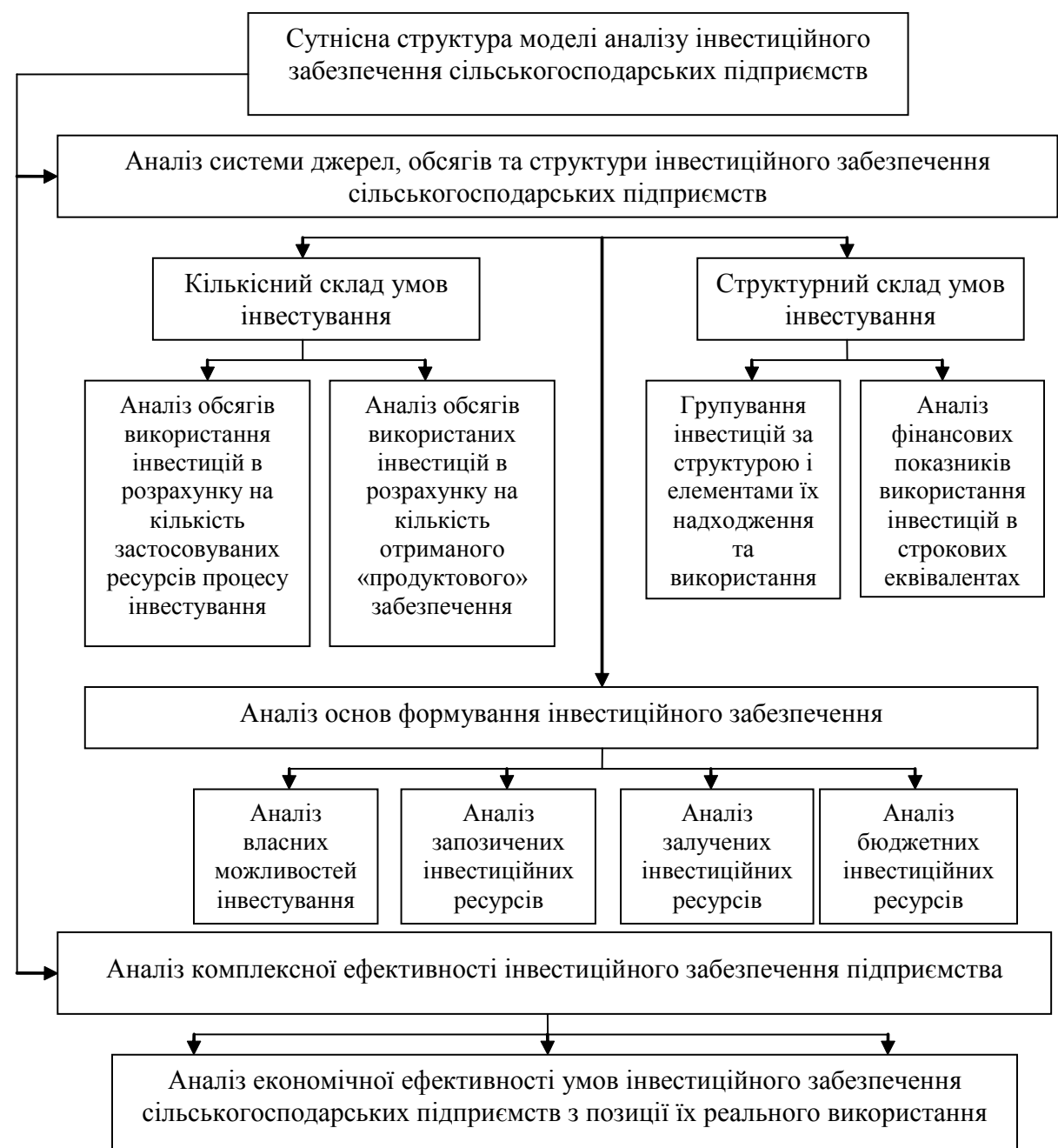

Рис. 1. Модель аналізу умов інвестиційного забезпечення сільськогосподарських підприємств у довгостроковій господарській альтернативі

Ажерело: власні розробки авторів.

ційне навантаження про можливі напрями змін і їхню інтенсивність [4]. 3 огляду на зазначені фактори необхідно докорінно перебудувати систему оцінки та аналізу умов ефективності залучення та використання інвестицій сільськогосподарськими підприємствами 3 позиції ї адресного функціонування, оскільки переважна більшість використовуваних інвестиційних ресурсів на умовах їх запозичення втрачають сенс адекватності розрахунків ефективності використання для самих сільськогосподарських підприємств. Переважно цей тип інвестиційного забезпечення стає мірою простого функціонування сільськогосподарських підприємств без врахування факторів їх можливого розширеного відтворення, оскільки плата за їх використання є надто високою в порівнянні $з$ високо розвинутими економічними формаціями. Цей фактор негативно позначається ну умовах безпосереднього сталого розвитку сільськогосподарських підприємств в довгостроковій господарській перспективі та унеможливлює формування економічних балансів між прибутком сільськогосподарських підприємств і зовнішнім середовищем його формування (стан земельних угідь, умови використання праці, якість продукції та ін.). Саме тому пропонуємо в методиці оцінки якісних та кількісних характеристик умов інвестиційного забезпечення сільськогосподарських підприємств чітко розмежовувати джерела формування та умови використання інвестицій 3 позиції їх вартості для самих об'єктів інвестування, а також більш детально та грунтовно оцінювати саме власні джерела інвестиційного забезпечення основних видів діяльності в структурі реального інвестування (рис. 1). Варто зауважити, що в практиці інвестування сільськогосподарських підприємств відсутні пропорційні стандарти щодо найбільш доцільної ефективності діяльності самих підприємств з позиції їх кількісного формування за структурними елементами вико- 


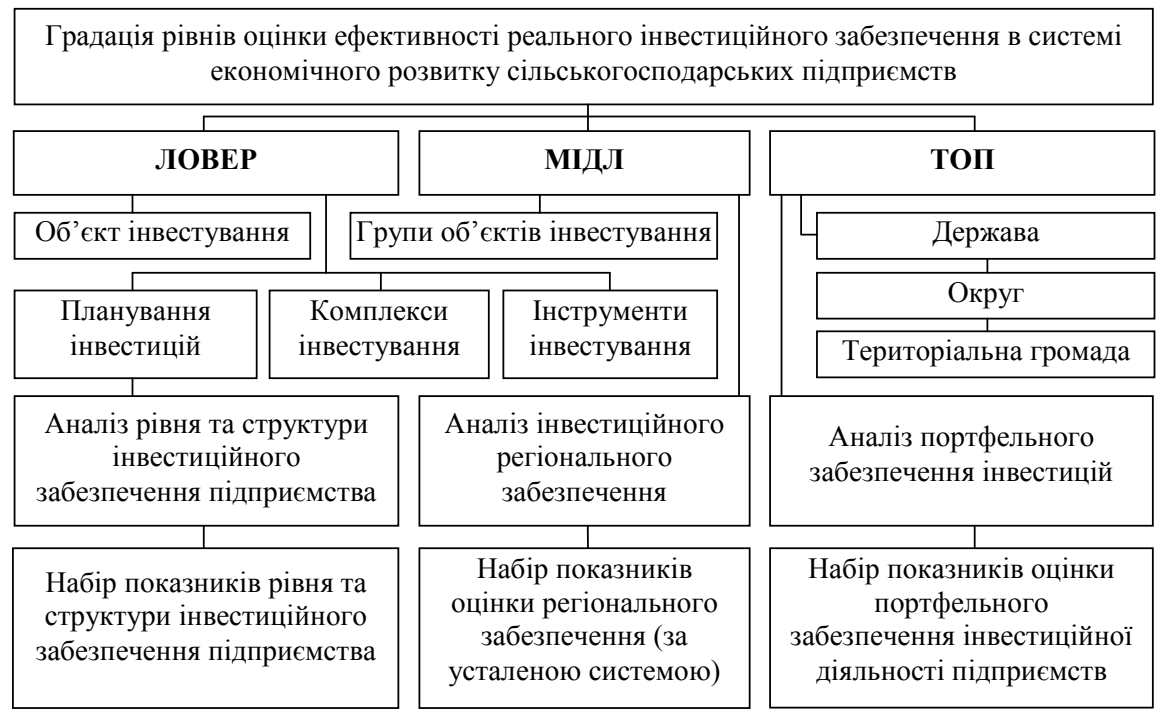

Рис. 2. Організаційно-економічна система оцінки ефективності реального інвестиційного забезпечення системи економічного розвитку сільськогосподарських підприємств у довгостроковій господарській альтернативі

Ажерело: власні розробки авторів.

ристання. В багатьох випадках значна кількість інвестицій не підтверджується кінцевими показниками їх ефективного використання, що стає актуальним для більшості великих аграрних формувань. Саме тому пропонується градація умов оцінки ефективності інвестиційної діяльності сільськогосподарських підприємств з урахуванням індивідуальних характеристик та умов інвестиційного забезпечення.

Запропоновану систему оцінки ефективності інвестиційного забезпечення сільськогосподарських підприємств доречно інтегрувати в існуючу систему загальної оцінки інвестиційного забезпечення сільськогосподарських підприємств за організаційно-економічними рівнями (рис. 2). Пропонуємо вдосконалити існуючу методику оцінки рівня ефективності інвестування сільськогосподарських підприємств 3 позиції ії градації за рівнями можливого застосування показників аналізу: врахування умов реструктуризаційної перебудови та утворення об'єднаних територіальних громад. У наведеному аспекті слід враховувати стратегію інвестиційного розвитку регіону, показники оцінки ефективності якої мають співпадати 3 основними показниками ефективності оцінки інвестиційного забезпечення самих сільськогосподарських підприємств; наступним кроком має стати узагальнення та систематизація введених у дію показників інвестиційної ефективності на ТОП-рівні управління що суттєво змінить структуру та підходи до формування якості статистичної інформації та перерозподілу са- мих інвестиційних ресурсів з високою якістю, безпосередньо підвищить рівень рентабельності сільськогосподарських капіталовкладень у довгостроковій господарській альтернативі.

Аослідження чинників вагомості наявних факторів впливу на кількість інвестицій у розвиток сільськогосподарських підприємств Житоми рської області вказує на доцільність проведених процесів інвестування протягом 20162020 рр. (табл. 1), а також констатує факт зро-

\section{Таблиця 1. Структура обсягу інвестиційного забезпечення сільськогосподарських підприємств Житомирської області 2016-2020 pp., \%}

\begin{tabular}{|c|c|c|c|c|c|c|c|}
\hline \multirow[b]{2}{*}{ Показник } & \multicolumn{5}{|c|}{ Рік } & \multicolumn{2}{|c|}{ Відхилення, +/- } \\
\hline & 2016 & 2017 & 2018 & 2019 & 2020 & $\begin{array}{c}2020 \mathrm{p} . \\
\text { до } \\
2016 \mathrm{p} .\end{array}$ & $\begin{array}{c}2020 \mathrm{p} . \\
\text { до } \\
2018 \mathrm{p} .\end{array}$ \\
\hline $\begin{array}{l}\text { Інвестиції у } \\
\text { матеріальні активи }\end{array}$ & 98,5 & 98,4 & 98,4 & 98,3 & 98,2 & $-0,3$ & $-0,2$ \\
\hline $\begin{array}{l}\text { у т. ч.: } \\
\text { в основний капітал }\end{array}$ & 69,6 & 70,3 & 71,1 & 71,4 & 72,5 & 2,9 & 1,4 \\
\hline $\begin{array}{l}\text { них: } \\
\text { капітальне } \\
\text { будівництво }\end{array}$ & 29,9 & 33,2 & 34,7 & 36,8 & 37,0 & 7,1 & 2,3 \\
\hline $\begin{array}{l}\text { машини, обладнання } \\
\text { та транспортні засоби }\end{array}$ & 39,7 & 37,1 & 36,4 & 34,6 & 35,5 & $-4,2$ & $-0,9$ \\
\hline $\begin{array}{l}\text { у довгострокові } \\
\text { біологічні активи } \\
\text { тваринництва }\end{array}$ & 3,4 & 2,9 & 2,8 & 3,4 & 3,3 & $-0,1$ & 0,5 \\
\hline $\begin{array}{l}\text { в інші необоротні } \\
\text { матеріальні активи }\end{array}$ & 3,1 & 1,5 & 1,3 & 1,4 & 1,3 & $-1,8$ & - \\
\hline у капітальний ремонт & 22,4 & 23,7 & 23,2 & 22,1 & 21,1 & $-1,3$ & $-2,1$ \\
\hline $\begin{array}{l}\text { Інвестиції у } \\
\text { нематеріальні активи }\end{array}$ & 1,5 & 1,6 & 1,6 & 1,7 & 1,8 & 0,3 & 0,2 \\
\hline Загальне значення & 100 & 100 & 100 & 100 & 100 & - & - \\
\hline
\end{tabular}

Ажерело: розраховано за даними Головного управління статистики у Житомирській області 2016-2020 pp. 


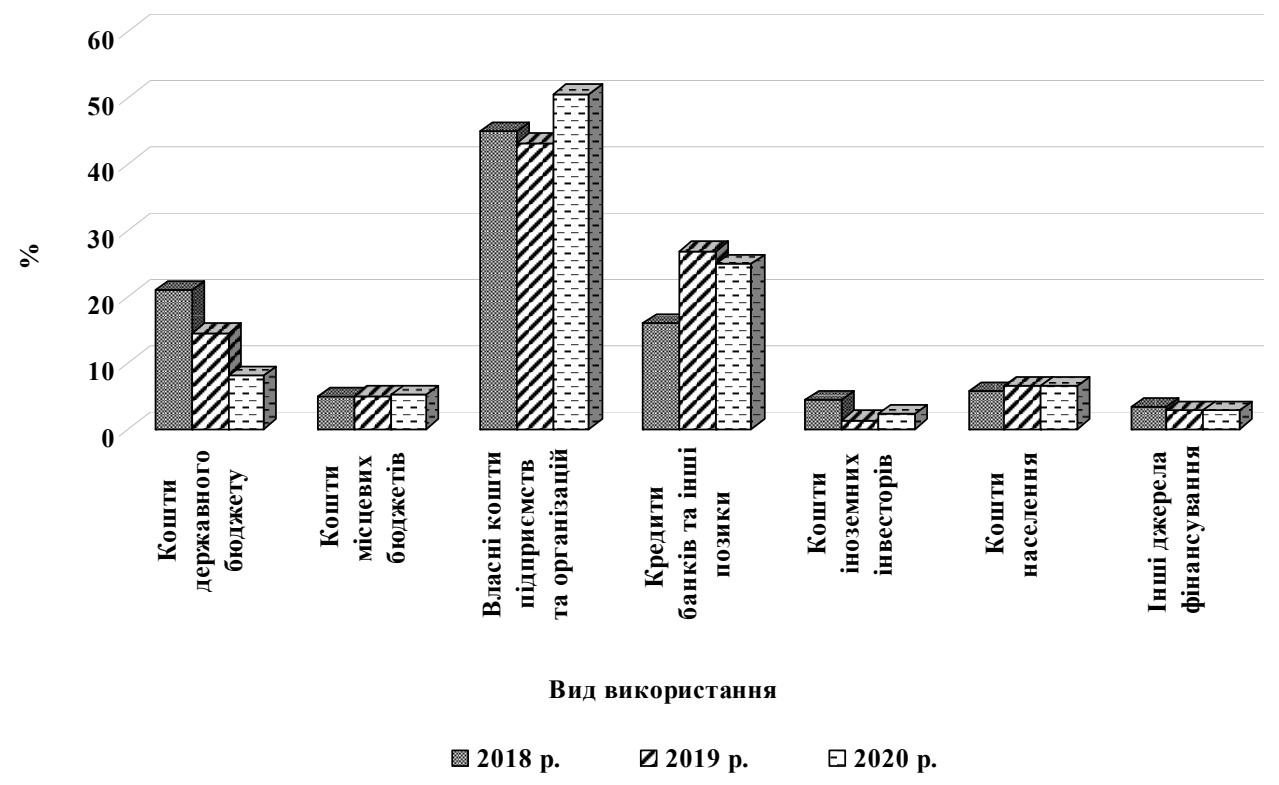

Рис. 3. Структура обсягу використання інвестицій сільськогосподарськими підприємствами Житомирської області за джерелами їх формування 2016-2020 рр., \%

Ажерело: розраховано за даними Головного управління статистики у Житомирській області 2016-2020 pp.

стання рівня їх якісного використання. Оскільки період 2019-2020 рр. характеризується наростанням рівня кризового середовища економічного середовища загалом, варто провести детальний аналіз структури інвестиційного забезпечення сільськогосподарських підприємств за мірою витрати коштів. Переважну більшість інвестицій вкладається в матеріальні активи сільськогосподарських підприємств 3 середнім показником 98,4\% у $2016-2020$ рр. у вигляді матеріальних активів, при цьому спостерігаються стрімкі зміни структури капіталов- кладень 2020 р в порівнянні з 2016 р. на 7,1 \% за статтею витрат капітального будівництва при одночасному зменшення витрат на 1,3 \% за статтею витрат капітального ремонту. Негативною тенденцією стає зменшення структури витрат на біологічні активи 2020 р. у порівнянні 3 2016 р. на 0,3 \% що в найближчій перспективі унеможливить функціонування галузі тваринництва.

Аналіз структури інвестиційних надходжень за джерелами використання сільськогосподарськими підприємствами Житомирської

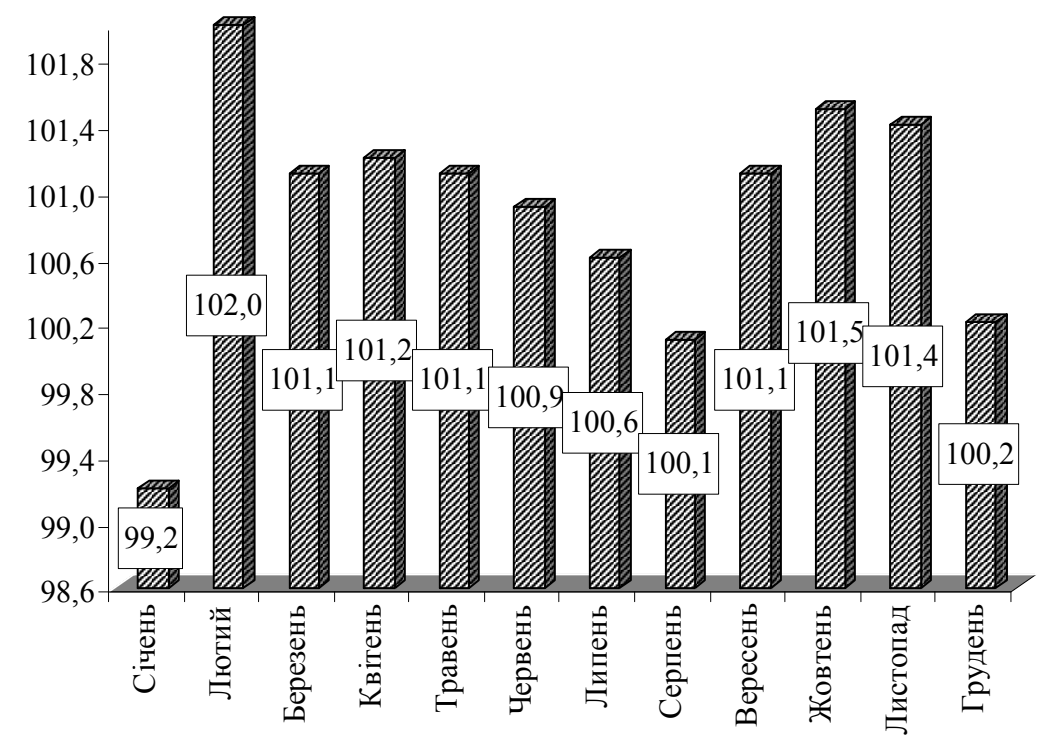

Рис. 4. Граничні потреби рівнів номінальної структури інвестиційного забезпечення сільськогосподарських підприємств Житомирської області, 2020 р.

Ажерело: власні розробки авторів. 
Таблиця 2. Аналіз впливу інтенсивності процесів сільськогосподарського виробництва на рівень інвестиційного забезпечення сільськогосподарських підприємств Житомирської області 2018-2020 рр.

\begin{tabular}{|c|c|c|c|c|c|}
\hline \multirow[t]{3}{*}{ Ознаки групування показників } & \multicolumn{3}{|c|}{$\begin{array}{c}\text { Загальна сума виробничих } \\
\text { витрат в розрахунку на } \\
\text { одиницю оброблювальної } \\
\text { посівної площі, } \\
\text { (тис. грн на } 1 \text { га) }\end{array}$} & \multirow{3}{*}{$\begin{array}{c}\text { III } \\
\text { група в } \\
\text { \% до I } \\
\text { групи }\end{array}$} & \multirow{3}{*}{ 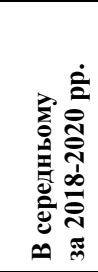 } \\
\hline & \multirow{2}{*}{$\begin{array}{c}\text { I } \\
\text { до } 3,0\end{array}$} & \multirow{2}{*}{$\begin{array}{c}\text { II } \\
3,0-4,0\end{array}$} & \multirow{2}{*}{$\begin{array}{c}\text { III } \\
\text { понад } \\
\mathbf{4 , 0}\end{array}$} & & \\
\hline & & & & & \\
\hline $\begin{array}{l}\text { Кількість сільськогосподарських } \\
\text { підприємств }\end{array}$ & 122 & 191 & 95 & 77,9 & 136,0 \\
\hline $\begin{array}{l}\text { Середня величина обсягу } \\
\text { виробничих витрат в розрахунку на } \\
1 \text { га сільськогосподарських угідь } \\
\text { (включно з адміністративними } \\
\text { витратами), тис. грн }\end{array}$ & 2,5 & 3,8 & 4,6 & 184,0 & 3,6 \\
\hline $\begin{array}{l}\text { Загальний показник валової } \\
\text { продукції підприємства, тис. грн }\end{array}$ & 4224,9 & 8341,7 & 23500,7 & 556,2 & 12022,4 \\
\hline $\begin{array}{l}\text { Середньозважений показник площі } \\
\text { сільськогосподарських угідь } \\
\text { підприємства, га }\end{array}$ & 411,2 & 847,6 & 2544,9 & 618,9 & 1267,9 \\
\hline $\begin{array}{l}\text { Середньорічний рівень } \\
\text { продуктивності праці в } \\
\text { абсолютному вимірі показника, } \\
\text { тис. грн }\end{array}$ & 311,7 & 554,8 & 644,2 & 206,7 & 503,6 \\
\hline $\begin{array}{l}\text { Використання земельних угідь } \\
\text { (показник отриманого } \\
\text { прибутку(збитку)), тис. грн }\end{array}$ & 3,4 & 4,1 & 5,2 & 152,9 & 4,2 \\
\hline Коефіцієнт окупності явних витрат & 0,97 & 1,12 & 1,29 & 133,0 & 1,1 \\
\hline $\begin{array}{l}\text { Рівень інвестиційного забезпечення } \\
3 \text { розрахунку на } 1 \text { підприємство, } \\
\text { тис. грн }\end{array}$ & 3914,1 & 6031,9 & 19354,2 & 494,5 & 9766,7 \\
\hline
\end{tabular}

Ажерело: власні дослідження авторів.

області 2018-2020 рр. вказує на вкрай низький рівень використання процесів реінвестування в значній мірі за рахунок відсутності вільних обігових коштів, впливу процесів сезонності на типологію виробництва та диспаритету цін. У 2020 р. у порівнянні з 2018 р. рівень використання власних інвестиційних ресурсів зріс на $3,7 \%$ що є безумовною позитивною тенденцією, аналогічний показник у розвинутих економічних системах складає 75-80\% (рис. 3 ).

У 2020 р. значного приросту за джерелами використання інвестицій склали кредити банків та інші позики в порівнянні з 2018 р. (9,3\%): скорочення програм підтримки сільськогосподарських товаровиробників; конкуренція на кредитному ринку; підвищення рівня рентабельності галузі сільськогосподарського виробництва. Незмінними залишаються надходження з місцевих бюджетів - при середньому значенні показника 2018-2020 рр. на рівні 5,4\%; кошти населення - 7,5\%, при скороченні асигнувань збоку іноземних інвесторів 2020 р. у порівнянні до 2018 р. - 2,8 \%.

У господарській практиці розрізняють технологічну і відтворювальну структуру інвестицій у основний капітал. Технологічна струк- тура інвестицій відображає співвідношення таких затрат: будівельні роботи, монтаж устаткування; придбання устаткування, яке вимагає монтажу, придбання інструменту, інвентаря; проєктні роботи; інші затрати. Відтворювальна структура інвестицій включає в себе такі напрями: нове будівництво; розширення, реконструкцію і технічне переоснащення діючих підприємств. Першочергове значення для підвищення ефективності діяльності підприємств області має покращення технологічної структури інвестицій у основний капітал, розподіл ї між основними складовими частинами. Прогресивність технологічної структури визначається збільшенням у складі інвестицій частки затрат на придбання активної частини основних виробничих засобів підприємств [5]. Перевищення рівня потреби у інвестиційних ресурсах створює передумови для негайного покриття за виниклої потреби. За проведеними розрахунками та структурою потреб (рис. 4) визначено можливі потреби за сезонністю ї використання сільськогосподарськими підприємствами Житомирської області в 2020 р. Перевищення рівня 100,0 \% вказує на відсутність можливостей задоволення інвестиційної 


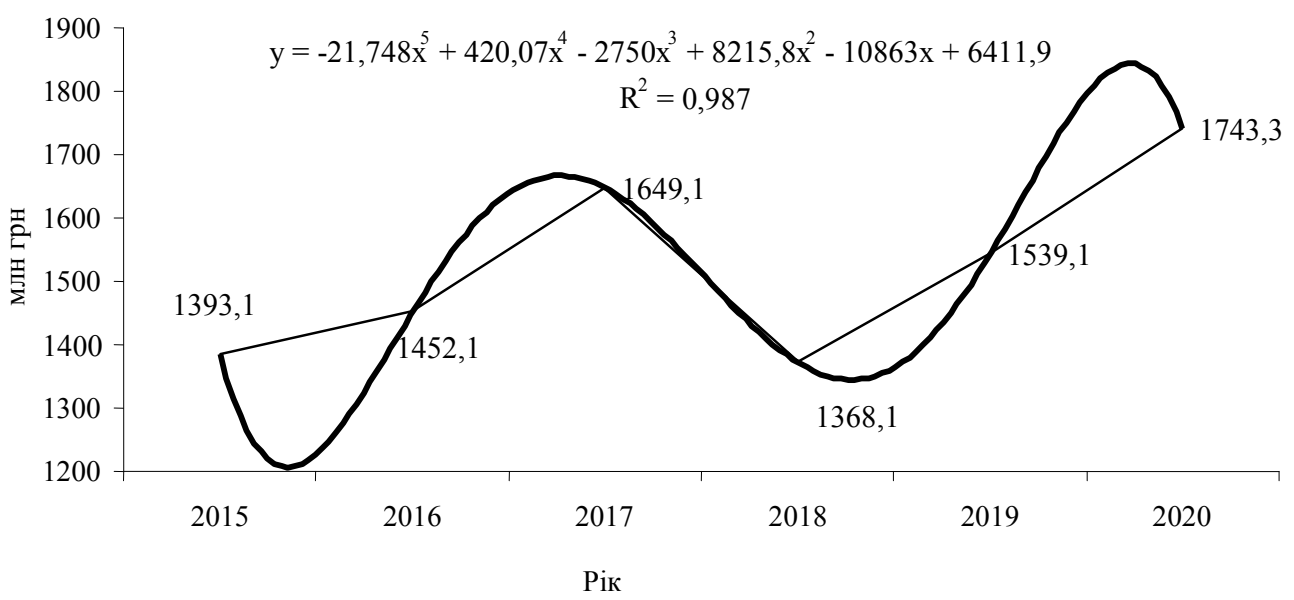

Рис. 5. Кореляційний аналіз динаміки інвестиційного забезпечення та рівня його ефективності в сільськогосподарських підприємствах Житомирської області, III групи масштабності 2015-2020 рр. з застосуванням поліноміальної лінії тренду (у п'ятій степені)

Ажерело: власні дослідження авторів.

потреби в порівнянні з можливістю абсолютного фінансового забезпечення даного господарського періоду.

Під час проведення аналізу та групування показників інтенсивності процесів сільськогосподарського виробництва сільськогосподарськими підприємствами Житомирської області в 2018-2020 pр. розроблено 3 групи якісної оцінки їх діяльності у співвідношенні до кількості наявно використаних інвестицій за різними джерелами їх надходження (табл. 2). Встановлено що найбільш ефективно використовують інвестиції сільськогосподарські підприємства III групи, в яких середній показник площі сільськогосподарських угідь складає 5562,2 тис. га при середньозваженій величині 12022,4 га, а рівень використання земельних угідь в порівнянні з I групою на 52,9 \% вищий.

Також у сільськогосподарських підприємствах з групи спостерігається значна відмінність у показниках окупності витрат $(+10 \%)$ в порівнянні $з$ підприємствами I групи; а також розмір інвестиційних надходжень більший ніж в 4,9 раза. Тобто кількість інвестицій має взаємозв'язок 3 якісними характеристиками ефективності цих сільськогосподарських підприємств. Не мало важливим фактором у доцільності якісної оцінки ефективності діяльності наведених інвестиційних груп має якісна оцінка земельних угідь підприємств.

Існують дослідження, які доводять, що великі підприємства більш ефективні при менших витратах, ніж невеликі сільськогосподарські підприємства. Більші фермерські господарства змогли залишатися вигідними при зниженні цін на сільськогосподарську продукцію в порівнянні з невеликими фермерами, i це пояснює тенденцію до більших господарств. Одна група науковців стверджує, що зростаючий розмір господарства зменшує витрати на гектар. Вони вивчали доходи сільськогосподарських підприємств та виявили, що більші фермерські господарства, як правило, вигідніше через нижчі постійні витрати. Проте деякі невеликі господарства були такими ж прибутковими, як великі, і існували також великі господарства, які були невигідними, отже, сам висновок про одиницю величини не є гарантією рентабельності. Вважалося, що диверсифікація є фактором підвищення прибутковості деяких малих господарств. Прибуток сільськогосподарського підприємства може збільшуватися завдяки економії на масштабі. Однак сільськогосподарські підприємства, що розвиваються, в кінцевому підсумку стикаються із зменшенням віддачі від масштабів, і це $є$ фактором визначення оптимального розміру сільськогосподарського підприємства. Оптимальне сільськогосподарське підприємство, як правило, використовує найбільш ефективну техніку та таку площу, яку можна ідеально обробляти, коли використання машин визначається місцевими по годними та кліматичними умовами. Скорочення прибутку відбувається, коли сільськогосподарське підприємство стає дуже великим, тому що дні, доступні сільськогосподарським виробникам для завершення основних польових операцій, $€$ обмеженим ресурсом. Це дослідження також має відношення до розробників аграрної політики, коли вони намагаються створити програми в умовах зміни галузевого ландшафту. Важливо, щоб ці люди розуміли фактори, що впливають на вибір розмірів зернового господарства та величину програм державної підтрим- 
ки, яку ці господарства можуть потребувати Аля управління ризиками [3].

Проведені дослідження для підприємств за масштабами діяльності III групи вказують на безпосередній та вагомий вплив якості земельних угідь на ефективність та рівень їх використання. За результативний показник (у) було встановлено рівень прибутку в розрахунку на 1 га сільськогосподарських підприємств; $\mathbf{x}-$ зведені виробничі та адміністративні витрати за абсолютним показником приросту протягом 2015-2020 рр., з врахуванням зміни масштабів виробництва та якості земельних угідь (середнє значення 81,2 бали). Тіснота зв'язку цих факторних ознак вказує на безпосередню їх залежність 3 високим рівнем коефіцієнта регресії (рис. 5).

Потрібно відзначити, що інвестиційний клімат зі всіма його проблемами у аграрному секторі України є сприятливим для залучення інвестицій, незважаючи на швидше негативне, ніж позитивне значення державних контролюючих органів у його якості. Це пояснюється тим, що значні масштаби сільськогосподарського бізнесу покривають існуючі витрати на подолання корупційних схем з боку представників держави, що перешкоджають ефективній закупівлі ресурсів, організації земельних та майнових відносин, залученню робочої сили, виробництву продукції, реалізації вироблених товарів та послуг, а також її переробці. Особливо стримують надходження інвестицій у сільськогосподарські підприємства з боку вітчизняних та закордонних інвесторів труднощі у залученні земель сільськогосподарського призначення та перешкоди у вільній реалізації виробленої продукції на зовнішніх ринках. Наявність великої кількості пайовиків, з якими потрібно заключати договори оренди землі, значно ускладнює процеси внутрішньогосподарського землеустрою агропромислових підприємств, проте таку схему, нині існування несформованого до кінця ринку земель, можна вважати оптимальною. 3 іншого боку, затягування процесів оформлення чи переоформлення приватної власності на земельний пай та подальша тривала реєстрація договорів їх оренди унеможливлює оперативне формування аграрними підприємствами земельних масивів для обробітку. Іншою проблемою залучення інвестицій у аграрний бізнес, яка одночасно може бути елементом системи інвестування є майже повна відсутність можливостей самостійного експорту виробленої традиційної 44 сільськогосподарської продукції, до якої відноситься зерно, насіння соняшника, овочі, фрукти, м'ясні або молочні вироби. Якщо у практичній площині експорт молочної продукції вдалось налагодити за рахунок об'єднання молокопереробних підприємств та їх інтеграційних утворень у великі альянси, то невеликі виробники зернової продукції вимушені продавати її посередникам, які формують крупні партії і вивозять закордон. При цьому сільськогосподарські товаровиробники неспроможні встановлювати ціну на свою продукцію, бо часто мають термінові фінансові зобов'язання на момент збору врожаю і потребуючи грошових коштів, реалізовують зерно на неприйнятних для себе умовах [2].

За результатами проведених досліджень у порівнянні з існуючими інвестиційними системами галузі сільськогосподарського виробництва провідних економічних систем сільськогосподарські підприємства з невеликими масштабами виробництва (до 425,5 га) недоотримують у структурному еквіваленті понад $40,5 \%$ існуючих фінансових ресурсів за рахунок діючої інвестиційної політики. При цьому агрохолдингові структури, в порівнянні з малими (фермерськими) господарствами, купують виробничі ресурси в середньому на 32,7 \% дешевше, цим самим створюючи умови для недобросовісної сільськогосподарської конкуренції.

\section{ВИСНОВКИ З ПРОВЕДЕНОГО ДОСЛІДЖЕННЯ I ПЕРСПЕКТИВИ ПОДАЛЬШИХ РОЗВІДОК У ЦЬОМУ НАПРЯMI}

Існуюча система умов інвестиційного забезпечення сільськогосподарських підприємств потребує докорінної перебудови з причин зміни адміністративно-територіального устрою, інвестиційної політики держави та нарощування стрімких процесів глобалізаційних перетворень на світових сільськогосподарських ринках. У свою чергу надмірна зарегульованість процесів інвестиційного забезпечення сільськогосподарських підприємств збоку держави створює надмірний тиск на швидкість та якість інвестиційного забезпечення, зменшуючи номінальний показник ефективності їх використання та періоду обороту.

Попри прибутковість галузі сільськогосподарського виробництва, більшість сільськогосподарських підприємств не спроможні ефективно проводити власну інвестиційну політику з причини низького рівня процесів їх реінвестування. В більшості випадків частка повернення в виробництво отриманого прибутку не перевищує 50 \%, що спонукає до застосуван- 
ня дороговартісних кредитних або інших запозичених ресурсів.

Структура обсягу інвестиційного забезпечення за джерелами витрат залишається стабільною протягом 2018-2020 рр. та не зазнає суттєвих змін. Більшість інвестицій в сільськогосподарські підприємства Житомирської області вкладаються у вигляді вкладень в основний капітал, понад 72 \%. Незадовільним залишається стан інвестування довгострокових біологічних активів тваринництва (3,3\%).

При оцінці граничних потреб рівнів номінальної структури інвестиційного забезпечення сільськогосподарських підприємств Житомирської області встановлено факт незабезпеченої інвестиційної потреби вільними фінансовими ресурсами підприємств протягом календарного періоду їх використання. Зазначена проблема спонукає сільськогосподарські підприємства до пошуку альтернативних джерел фінансування у вигляді запозичених ресурсів, котрі переважно є досить дороговартісними.

Під час проведення групування показників рівня ефективності діяльності сільськогосподарських підприємств Житомирської області протягом 2018-2020 рр. відносно рівня та умов їх інвестиційного забезпечення встановлено що найдоцільніше інвестувати в сільськогосподарські підприємства з середнім розміром виробничої площі 2544,9 га та з загальною сумою виробничих витрат у розрахунку на одиницю оброблювальної посівної площі понад 4 тис. грн на 1 га.

Основними умовами якісного та кількісного поліпшення умов інвестиційного забезпечення сільськогосподарських підприємств Житомирської області мають стати: докорінна перебудова системи організаційно-правового забезпечення та реалізації процесів інвестиційного забезпечення 3 врахуванням реалізованих умов процесу децентралізації; запровадження регіональних інвестиційних програм на пільгових умовах їх використання для самих інвесторів; стимулювання процесів розвитку інвестиційного забезпечення сільськогосподарських підприємств на умовах їх сталого функціонування як запоруки їх ефективної діяльності в стратегічній перспективі; зменшення умов впливу на інвестиційне забезпечення бюрократичних процедур та їх уникнення в майбутньому; раціональний вплив фіскальної політики, що має виявлятися в лояльних податкових відрахуваннях а також використання різного роду податкових пільг відносно сільськогосподарських проєктів; залучення та використання прогресивного інвестиційного досвіду розвинутих економічних систем світу в поєднанні 3 прогресивними виробничими технологіями при врахуванні розвитку умов соціального середовища сільських територій.

\section{$\Lambda$ ітература:}

1. Кісіль M.I. Пріоритетні напрями інвестицій у аграрну сферу України в умовах нестабільності. Вісник ХНАУ. Сер. "Економічні науки". ХНАУ. 2015. № 1. С. 83-90.

2. Коденська М.Ю. Мотиваційні чинники інвестиційного забезпечення розвитку аграрно промислового виробництва. Вісник Академії праці соціальних відносин Федерації профспілок України. 2013. № 2. С. 62-66.

3. Аупенко Ю.О., Захарчук О.В. Інвестиційне забезпечення інноваційного розвитку сільського господарства України. Економіка АПК. 2018. № 11 С. 9-18.

4. Однорог М.А. Інвестиційне забезпечення у сільськогосподарському секторі економіки України. Науковий вісник Полісся. 2016. № 4 (8). Ч. 1. С. $142-148$.

5. Владимирська Н.I. Особливості міжнародного інвестування в економіку України. Економічні інновації. 2019. Т. 21. Вип. 3 (72). C. $26-36$.

6. Аемчук H.I., Кисельова М.С. Інвестиційне забезпечення сільськогосподарських підприємств. Агросвіт. 2016. № 24. С. 21-26.

\section{References:}

1. Kisil', M.I. (2015), "Priority areas of investment in the agricultural sector of Ukraine in conditions of instability", Bulletin of KhNAU, vol. 1, pp. 83-90.

2. Kodens'ka, M.Yu. (2013), "Motivational factors of investment support for the development of agro-industrial production", Visnyk Akademii pratsi sotsial'nykh vidnosyn Federatsii profspilok Ukrainy, vol. 2, pp. 62-66.

3. Lupenko, Yu.O. and Zakharchuk, O. V. (2018), "Investment support of innovative development of agriculture of Ukraine", Ekonomika APK, vol. 11, pp. 9-18.

4. Odnoroh, M.A. (2016), "Investment support in the agricultural sector of Ukraine", Naukovyj visnyk Polissia, vol. 4 (8), pp. 142-148.

5. Vladymyrs'ka, N.I. (2019), "Features of international investment in the economy of Ukraine", Ekonomichni innovatsii, vol. 3 (72), pp. 26-36.

6. Demchuk, N.I. and Kysel'ova, M.S. (2016), "Investment support of agricultural enterprises", Ahrosvit, vol. 24, pp. 21-26.

Стаття надійшла до редакчї 04.10.2021 p. 
УАK 338.4

О. М. Кватирко, аспірант, Національний університет біоресурсів і природокористування України, м. Київ ORCID ID: 0000-0003-0773-4237

\title{
ЗАБЕЗПЕЧЕННЯ
}

\section{КОНКУРЕНТОСПРОМОЖНОСТI $\Lambda І$ СОВОГО СЕКТОРУ НА ЕКОАОГО- ЕКОНОМІЧНИХ ЗАСАААХ: ПРИНЦИПИ ТА ОСОБАИВОСТІ}

\author{
O. Kvatyrko, \\ Postgraduate student, National University of Life and Environmental Sciences of Ukraine
}

\begin{abstract}
ENSURING THE COMPETITIVENESS OF THE FOREST SECTOR BASED ON ECOLOGICAL AND ECONOMIC PRINCIPLES: PRINCIPLES AND FEATURES
\end{abstract}

Встановлено, що конкурентоспроможність лісового сектора - це зАатність його складових (лісового господарства, деревообробного виробництва, лісохімічної та целюлозно-паперової промисловості) та відповідно суб'єктів лісогосподарської та деревообробної діяльності ефективно використовувати наявні конкурентні переваги, які виникають внаслідок об'єктивних природно-ресурсних чинників відновлення та відтворення лісоресурсного потенціалу, а також внаслідок побудови ефективних управлінських систем у сировинному та переробному сегментах, у межах котрих забезпечується найрезультативніше поєАнання виробничих ресурсів - матеріальних, фінансових та Аюдських. У статті обгрунтовується доцільність формування сучасного теоретико-метоАичного підгрунтя зростання рівня конкурентоспроможності лісового сектору як необхідної переАумови посилення впливу господарського освоєння лісоресурсного потенціалу на темпи соціально-економічного піднесення. Аоведено, що в нинішніх умовах турбулентності та волатильності базових ринків, а також збільшення кількості виробників лісопродукції необхідно здійснювати модернізацію виробничо-технічної бази та системи управління дісогосподарською та деревообробною діяльністю. Обгрунтовано, що модернізація має стати пріоритетом корпоративної політики підприємницьких структур у сфері лісового господарства, деревообробного та лісохімічного виробництва, целюлозно-паперової промисловості. Встановлено, що забезпечення конкурентоспроможності лісового сектора на еколого-економічних засаАах має базуватися на комплексі принципів: невиснажливості, розширеного відтворення лісоресурсного потенціалу, еколого-економічної рівноваги, комплексності, інноваційної спрямованості, галузевої еквівалентності, пріоритетності ресурсозбереження, енергетичної доцільності, прискореної імплементації кращих практик лісового менеджменту країн ЄС у практику вітчизняного лісогоспоАарювання, дотримання вимог цифрової трансформації, компліментарності. Обгрунтовано, що в нинішніх умовах глобальної нестабільності важливою детермінантою підвищення рівня конкурентоспроможності постійних лісокористувачів виступає дотримання принципу комплексності, тобто максимально ефективного використання матеріально-речової субстанції деревної та недеревної сировини, а також усунення практики втрати лісосировини у різних фазах лісопродуткового ланцюга та забезпечення утилізації лісосічних віАходів і віАходів деревообробки та лісопилення. 
It is established that the competitiveness of the forest sector is the ability of its components (forestry, woodworking production, forest chemical and pulp and paper industry) and, accordingly, the subjects of forestry and woodworking activities to effectively use the existing competitive advantages that arise due to objective natural resource factors of restoration and reproduction of forest resource potential. As well as due to the construction of effective management systems in the raw materials and processing segments, within which the most effective combination of production resources-material, financial and human. The article substantiates the expediency of forming a modern theoretical and methodological basis for increasing the level of competitiveness of the forest sector as a prerequisite for strengthening the impact of economic development of forest resource potential on the rate of social and economic recovery. It is proved that in the current conditions of turbulence and volatility of the basic markets, as well as an increase in the number of producers of forest products, it is necessary to modernize the production and technical base and management system for forestry and woodworking activities. It is proved that modernization should become a priority of the corporate policy of business structures in the field of forestry, woodworking and forestry chemical production, pulp and paper industry. It is established that ensuring the competitiveness of the forest sector on ecological and economic principles should be based on a set of principles. They are insubordination, expanded reproduction of forest resource potential, ecological and economic balance, complexity, innovation orientation, industry equivalence, priority of resource conservation, energy expediency, accelerated implementation of the best practices of forest management of EU countries in the practice of domestic forestry, compliance with the requirements of digital transformation, complementarity.

It is proved that in the current conditions of global instability, an important determinant of increasing the level of competitiveness of permanent forest users is compliance with the principle of complexity. That is, the most efficient use of the material and material substance of wood and non-wood raw materials, as well as eliminating the practice of losing raw materials in different phases of the forest product chain and ensuring the disposal of cutting waste and woodworking and sawmill waste.

Ключові слова: конкурентоспроложність, лісовий сектор, комплексність, ресурсозбереження, еколого-економічна рівновага, иифрова трансформачіл.

Key words: competitiveness, forest sector, complexity, resource conservation, ecological and economic balance, digital transformation.

\section{ПОСТАНОВКА ПРОБЛЕМИ У ЗАГАЛЬНОМУ ВИГЛЯДІ ТА ІІЇ ЗВ'ЯЗОК ІЗ ВАЖЛИВИМИ НАУКОВИМИ ЧИ ПРАКТИЧНИМИ ЗАВДАННЯМИ}

Міжгалузева спрямованість розвитку лісового сектора національного господарства вимагає розроблення сучасних механізмів забезпечення його конкурентоспроможності, особливо в нинішніх умовах поглиблення децентралізації влади та інституціональної трансформації системи управління лісовим господарством. Аля того, щоб механізми забезпечення конкурентоспроможності лісового сектора не суперечили один одному, а були взаємодоповнюючими, необхідним є обгрунтування комплексу принципів, дотримання котрих при здійсненні заходів щодо використання конкурентних переваг лісогосподарського та деревообробного виробництва дасть змогу повною мірою врахувати екологічну функцію лісів і їх роль у відтворенні господарських комплексів багатолісних районів і тим самим не порушити еколого-економічну рівновагу та стійкість лісових біогеоценозів. Також важливого значення при проєктуванні заходів щодо підвищення конкурентоспроможності лісового сектора та його основних ланок набуває врахування особливостей функціонування постійних лісокористувачів та суб'єктів господарювання, які забезпечують переробку деревини і виробництво широкого спектра дерев'яної продукції. 3 огляду на сказане розроблення комплексу принципів забезпечення конкурентоспроможності лісового сектора на загальнонаціональному та регіональному рівнях, а також врахування особливостей використання конкурентних переваг суб'єктів лісогосподарського та деревообробного виробництва є важливими завданнями теорії, методології та практики управління конкурентоспроможністю галузі та суб'єктів господарської діяльності.

\section{АНАЛІЗ ОСТАННІХ ДОСЛІДЖЕНЬ І ПУБЛІКАЦІЙ}

Багатофункціональне призначення лісового сектора, що випливає з виробничо-тех- 
нічної та ресурсної неоднорідності його складових，вимагає диференційованого підходу до вибору пріоритетів та механізмів підвищення рівня конкурентоспроможності цього сектору загалом та окремих його складових. Аля адекватного реальному стану речей розуміння сутнісних та прикладних характеристик конкурентоспроможності лісового сектора необхідно уточнити сутність поняття "конкурентоспроможність" та основні принципи і особливості забезпечення прийнятного рівня конкурентоспроможності в сировинному та переробному сегментах лісового сектора національного господарства.

У працях I. Андрійчука, Н. Валінкевич, I. Губарєвої, Е. Аобровольської, М. Аубини, О. Зінкевич, С. Іщук, М. Кизима, Н. Покотильської, $\Lambda$. Созанського, А. Фітісова, I. Ярошенко та інших [1-7] розглядається сутнісна характеристика категорії "конкурентоспроможність", визначаються прикметні ознаки конкурентних переваг як базової умови зростання рівня конкурентоспроможності, обгрунтовується важливість зростання рівня конкурентоспроможності економіки загалом та окремих видів діяльності зокрема для забезпечення прийнятних темпів економічного зростання, виявляється вплив глобальної нестабільності на основні детермінанти конкурентоспроможного матеріального виробництва, виокремлюється змістовна характеристика конкурентоспроможності стосовно суб'єктів лісогосподарського, деревообробного, меблевого та целюлозно-паперового виробництва, але не повною мірою сформульовані принципи забезпечення конкурентоспроможності лісового сектора 3 врахуванням глобальних трендів та викликів децентралізації, а також враховані особливості використання конкурентних переваг у сировинній та переробній ланці лісопродуктового ланцюга.

\section{ЦІЛІ СТАТTІ}

Цілями статті $є$ ідентифікація особливостей забезпечення конкурентоспроможності лісового сектора та обгрунтування комплексу принципів, які мають бути враховані при виборі пріоритетів використання конкурентних переваг сировинної та переробної ланок лісопродуктового ланцюга в умовах посилення глобальної економічної турбулентності та поглиблення децентралізації влади і реформи місцевого самоврядування.

\section{ВИКЛАД \\ ОСНОВНОГО МАТЕРІАЛУ ДОСЛІДЖЕННЯ}

Важливою теоретичною позицією є те, що конкурентоспроможність лісового сектора значною мірою визначається конкурентоспроможністю лісогосподарських підприємств. Тому необхідною умовою комплексного підходу до розроблення механізмів підвищення конкурентоспроможності лісового сектора є розрахунок показників конкурентоспроможності постійних лісокористувачів, якими виступають державні та комунальні лісогосподарські підприємства. Проблема підвищення рівня конкурентоспроможності лісогосподарських підприємств актуалізувалася у зв'язку з тим, що лісовий сектор, як вважають Е. Аобровольська та Н. Покотильська, зазнав значних структурних та інституціональних перетворень у зв'язку з переходом до системи ринкових відносин [3, c. 79].

Аля визначення фундаментальних положень використання базових чинників забезпечення прийнятного рівня конкурентоспроможності лісогосподарських підприємств та особливостей використання конкурентних переваг окремих сегментів лісового сектора необхідно максимальною мірою врахувати специфіку лісовідтворення та охорони лісів, а також переробки деревини. Виходячи 3 того, що основними суб'єктами лісового сектору виступають державні лісогосподарські підприємства, зосередимо увагу на конкурентоспроможності первинної ланки національного господарства, тобто підприємства.

Попри те, що існують уніфіковані підходи до забезпечення росту конкурентоспроможності промислових підприємств, як правило мають місце специфічні умови підвищення рівня конкурентоспроможності в окремих галузях промислового виробництва. Стосовно лісогосподарських підприємств дане твердження $€$ найбільш прийнятним 3 огляду на те, що названі суб'єкти господарської діяльності найбільшою мірою залежать від природно-ресурсних факторів, представлених лісовими ресурсами. Обмежуючим чинником тут виступає тривалий період між посадкою (відновленням) лісу та його стиглістю. Це виступає однією з основних особливостей забезпечення конкурентоспроможності лісового сектора як в умовах підйому національної економіки, так і в умовах глибокої стагнації господарського комплексу.

Аержавні лісогосподарські підприємства, які в останні роки втратили фінансову підтрим- 
ку держави на лісовідновлення, мають використати найкращі практики комерційного розрахунку, щоб втриматися на традиційних ринках. Більше того, це необхідно 3 огляду на те, що традиційне джерело доходів, а саме виручка від експорту необробленої деревини, для цих суб'єктів виробничо-господарської діяльності в теперішніх умовах поки недоступне. Водночас необхідно врахувати весь комплекс чинників та особливостей, які здійснюють вплив на конкурентоспроможність лісогосподарських виробництв. Особливо прискіпливо необхідно підходи до імплементації передових практик екологічного менеджменту у вітчизняну практику лісогосподарювання. Екологічний менеджмент лісокористування, на думку А. Фітісова, є однією із умов підвищення конкурентоспроможності та ефективності роботи лісогосподарських підприємств та галузі загалом [6, c. 187].

Базовою умовою забезпечення прийнятного рівня конкурентоспроможності лісогосподарських підприємств є максимізація використання конкурентних переваг названих суб'єктів господарювання. Водночас важливого значення набуває структуризація конкурентних переваг постійних лісокористувачів, якими вони володіють та набувають у процесі виробництва продукції, надання послуг та виконання робіт. Тому необхідно розглянути існуючі підходи вітчизняних вчених відносно ідентифікації конкурентних переваг суб'єктів господарювання в загальному. Зокрема, Н. Валінкевич стратегічною конкурентною перевагою підприємства визначає модернізацію [2, с. 155]. Тому модернізація має стати основним пріоритетом корпоративної політики суб'єктів господарювання у сфері лісового господарства, деревообробного та лісохімічного виробництва, целюлозно-паперової промисловості.

Забезпечення конкурентоспроможності лісогосподарських підприємств, які здійснюю господарське освоєння лісоресурсного потенціалу та залучають деревну та недеревну сировину, а також несировинні корисності лісу у господарський обіг, виступає важливою складовою конкурентоспроможності лісового сектора національної економіки. Водночас лісогосподарські підприємства формують лише ресурсну базу для переробних ланок лісового сектора, тому значною мірою і від конкурентоспроможності продукції лісопильного, стругального, столярного, меблевого, лісохімічного та целюлознопаперового виробництва залежить конкурен- тоспроможність названого сектора національного господарства. Фактично перераховані виробництва становлять основу лісопромислового комплексу, який має відмінні від сировинного (лісогосподарського) риси, тому необхідно враховувати особливості забезпечення конкурентоспроможності у деревообробці та меблевому виробництві, щоб активувати максимальну кількість галузевих та виробничо-технічних чинників, що позитивно впливають на конкурентоспроможність лісового сектора.

3 викладеного вище випливає висновок, що забезпечення конкурентоспроможності лісового сектора є складним багатоаспектним процесом з огляду на функціональну та виробничо-технічну неоднорідність його основних складових - лісового господарства та переробної ланки. 3 метою досягнення максимально позитивного результату в цьому напрямі політика підвищення рівня конкурентоспроможності лісового сектора має базуватися на комплексі принципів, які дадуть можливість отримати очікувані результати щодо використання конкурентних переваг сировинного та переробного сегментів і при цьому не нанести негативного впливу на лісистість території та приріст деревної маси (рис. 1).

Визначаючи пріоритети підвищення рівня конкурентоспроможності лісового сектору необхідно враховувати принцип невиснажливості використання лісоресурсного потенціалу, щоб поставлені цілі ефективнішого використання конкурентних переваг постійних лісокористувачів не перетворювалися в самоціль максимізації прибуткових надходжень будь-якою ціною, в тому числі і за рахунок надмірного використання запасів деревини. Також цей принцип передбачає ощадливе використання недеревної складової лісоресурсного потенціалу, зокрема лікарських рослин, грибів, ягід та інших елементів лісового біорізноманіття, в тому числі і фауністичної складової, що має враховуватися при визначенні пріоритетів заготівлі другорядних лісових матеріалів, побічного лісокористування, ведення мисливського господарства.

Одним 3 базових принципів забезпечення конкурентоспроможності лісового сектору $€$ принцип розширеного відтворення лісоресурсного потенціалу, який базується на дотриманні вимог безперервного лісокористування, що визначаються таксаційними та лісовпорядними документами, зокрема в частині здійснення науково обгрунтованого комплексу лісогосподарських заходів щодо забезпечення необ- 


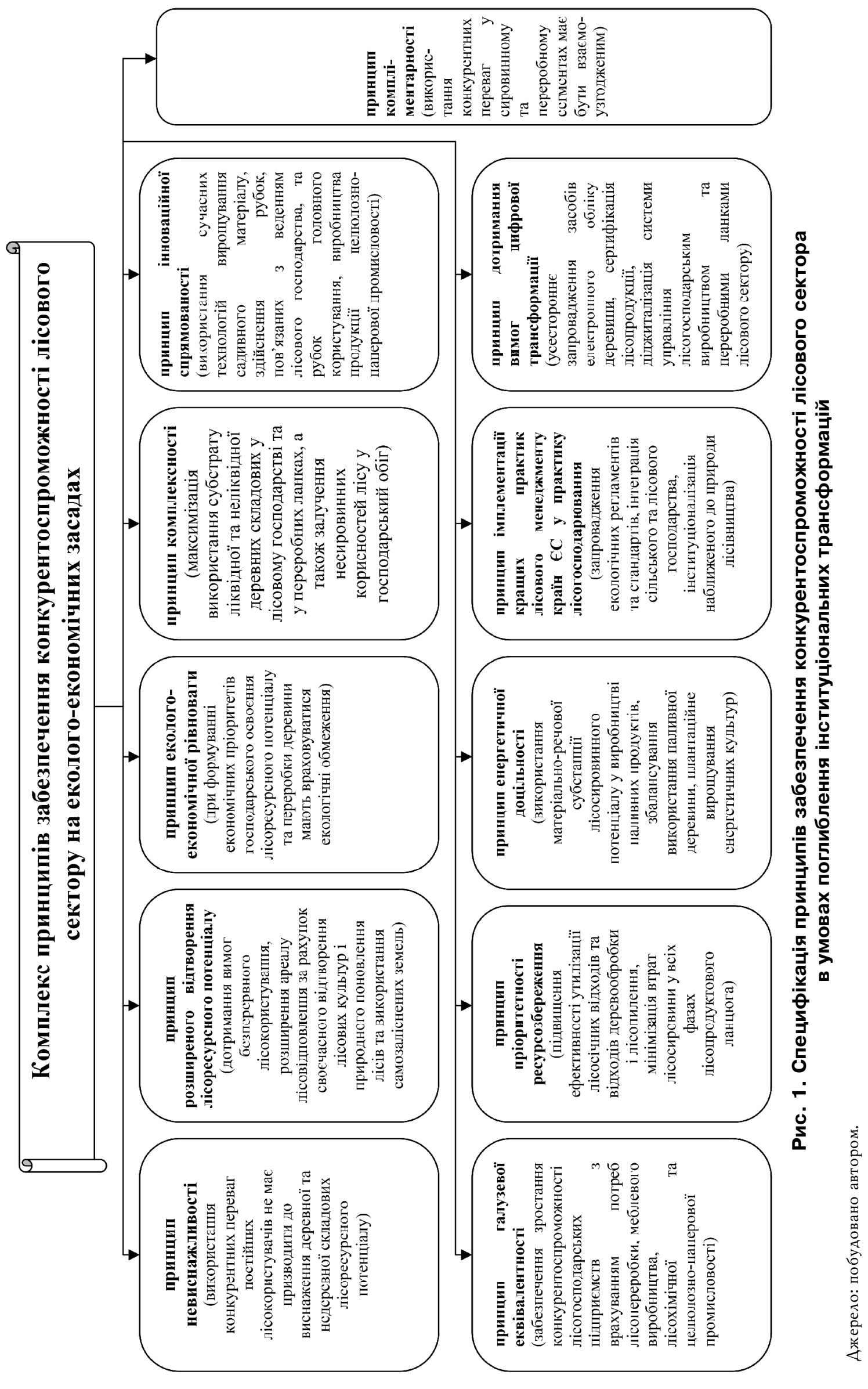


хідної повноти насаджень та покращення характеристик основних лісоутворюючих порід.

Зазначений принцип також передбачає неухильне дотримання вимог стосовно заліснення територій, де проводилися суцільні рубки, зокрема рубки головного користування та окремі види рубок, що пов'язані з веденням лісового господарства, а також забезпечення максимальних масштабів природного лісовідновлення, що, як правило, характеризується високим рівнем приживлюваності насаджень.

Аотримання принципу розширеного відтворення лісоресурсного потенціалу також пов'язане 3 необхідністю заліснення малопродуктивних сільськогосподарських угідь, що не забезпечують навіть мінімального рівня доходності за умови їх використання у продуктивному сільськогосподарському обігу. 3 огляду на це, постійні лісокористувачі мають забезпечувати перманентний контакт з органами місцевого самоврядування, зокрема в частині переведення малопродуктивних сільськогосподарських угідь в землі лісового фонду. Резерви для цього в об'єднаних територіальних громад значні, оскільки в результаті прийняття законодавства про дерегуляцію земельних відносин вони отримали у комунальну власність сільськогосподарські землі державної власності поза межами населених пунктів.

Більше того, значна частина таких земель є самозалісненою і їх повернення у сільськогосподарський обіг фактично унеможливлюється, а проведення певного комплексу лісогосподарських заходів, зокрема рубок проріджування та освітлення, дасть змогу сформувати всі необхідні умови для повноцінного росту лісоутворюючих порід. Самозаліснені землі займають значні площі в зоні масштабних осушувальних меліорацій - це, як правило зона Полісся, де функціонують потужні лісогосподарські підприємства, які мають на своїй базі спеціалізовані підрозділи, що здатні забезпечити комплекс лісооблаштувальних робіт і створити умови для науково обгрунтованого ведення лісового господарства на цих територіях.

Враховуючи те, що усі ланки лісового сектора, зорієнтовані на освоєння і переробку матеріально-речової субстанції лісових ресурсів, надзвичайно важливо при реалізації заходів щодо підвищення рівня конкурентоспроможності лісового сектора враховувати принцип еколого-економічної рівноваги, що передбачає урівноваження господарських пріоритетів 3 пріоритетами відтворення, відновлення та охо- рони лісових ресурсів, зокрема шляхом здійснення періодичного моніторингу реальних запасів деревини, приросту деревної маси, зрушень у породно-віковій структурі. Вагомого значення набуває своєчасне виявлення вогнищ поширення хвороб лісу та лісових шкідників, які можуть призвести до загибелі лісових насаджень, а також зменшення видів лісового біорізноманіття. Аотримання названого принципу також передбачає нарощення асигнувань на розбудову природоохоронної інфраструктури постійних лісокористувачів, зокрема оновлення та модернізацію пожежних машин, здійснення комплексу агротехнічних заходів, які упереджують поширення пожежонебезпечних процесів.

Як показує світова та європейська практика, лісогосподарський бізнес є, як правило, прибутковим за рахунок комплексного використання складових лісоресурсного потенціалу, що дає можливість диверсифікувати виробничу програму як за рахунок виробництва нових видів товарів, так і за рахунок розширення спектра виконання робіт і надання послуг. 3 огляду на це, принцип комплексності при досягненні пріоритетів конкурентоспроможності лісового сектора є необхідною умовою підвищення рівня капіталізації лісогосподарської та деревообробної діяльності, а також усунення практики втрати лісосировини у різних фазах лісопродуткового ланцюга. Зростання комплексності використання лісоресурсного потенціалу означає введення додаткових потужностей у сферу мисливського господарства, зокрема за рахунок збільшення поголів'я лісової фауни, і формування нових сегментів лісового сектора за рахунок максимізації використання усіх можливих субстратів лісосировини у продуктивному обігу (налагодження виробництва паливних пелет та брикетів на основі утилізації деревних відходів та інших складових неліквідної деревини). Суттєве зростання рівня комплексності використання лісоресурсного потенціалу відбувається за умови комерціалізації екосистемних послуг, що продукує лісовий біогеоценоз, які полягають у грунтозахисній, водорегулюючій, рекреаційній функції лісів.

Пріоритети конкурентоспроможності лісового сектора будуть досягнуті прискореними темпами за умови усестороннього застосування процесних та продуктових інновацій як у сировинному, так і в переробному сегменті. Тобто мова йде про дотримання принципу інноваційної спрямованості, який полягає в перманентному застосуванні нових методів та техно- 
логій ведення лісового господарства, зокрема лісорозведення та здійснення лісогосподарських заходів, лісозаготівель, переробки деревини. Також цей принцип передбачає застосування інноваційних методів вирощування садивного матеріалу та вибіркової системи рубок для збалансування вікової та породної структури лісового фонду, а також найновіших технологічних досягнень, які дадуть можливість підвищити ефективність виробництва у стругальному, лісопильному, меблевому виробництві, у лісохімічній та целюлозно-паперовій промисловості, а також в індустрії утилізації деревних відходів.

Однією з необхідних умов поступального розвитку лісового сектора, виходячи з передового іноземного досвіду, є збалансований розвиток його основних складових: сировинної та переробної. 3 огляду на це, необхідно забезпечувати компліментарність між стратегічними пріоритетами розвитку лісогосподарського виробництва та переробних ланок, щоб упередити прояви виникнення галузевих перегинів, що однозначно можуть призвести до виснажливого використання найбільш ліквідної складової лісоресурсного потенціалу, а це порушить еколого-економічну рівновагу в лісових біогеоценозах та закладе ризик дефіциту лісосировини в середньостроковій та довгостроковій перспективі. Тобто необхідно закладати стимули Аля суб'єктів деревообробного виробництва, щоб вони впроваджували технологічні процеси, які передбачають залучення у відтворювальний процес не лише найбільш ліквідної деревини, але й порубкових решток та іншої некондиційної лісосировини. Максимальною мірою принцип компліментарності буде дотриманий за умови створення міжгалузевих об'єднань суб'єктів лісогосподарського та деревообробного підприємництва, де буде можливість на спільній інституційній основі визначати як пріоритети господарського використання деревини, так і пріоритети відновлення лісоресурсного потенціалу.

\ісовий сектор охоплює певну кількість галузей, які спеціалізуються як на лісівничій діяльності, так і на переробці деревини і виготовленні готових дерев'яних виробів. Гіпертрофований розвиток окремих переробних ланок може призвести до підвищення рівня матеріаломісткості виготовлення готової продукції і, як наслідок, прискорити процеси виснаження лісоресурсної бази. Тому необхідно забезпечувати дотримання принципу галузевої еквівалентності, що передбачає збалансований розвиток як комплексних лісогосподарських підприємств, які охоплюють як власне ведення лісового господарства і деревообробку, так i підприємств, які спеціалізуються на суто лісопиленні, стругальному та меблевому виробництві, виробництві продукції лісохімії та целюлозно-паперової промисловості. За таких умов буде відбуватися поступове зниження питомих витрат лісосировини на виготовлення лісопродукції і забезпечуватиметься ріст капіталізації лісового сектору загалом.

Сьогодні маркером функціонування виробничих підприємств, які працюють на основі використання природної сировини, є максимально можливе впровадження технологій, які забезпечують економію первинної та вторинної сировини, що у підсумку призводить до зростання рівня прибутковості. Аля лісового сектора це особливо актуально, оскільки подолання дефіцитності лісосировини можна долати через впровадження ресурсозберігаючих технологій як у сировинному, так і в переробному сегментах. Тобто в основу корпоративної політики лісогосподарських підприємств та суб'єктів деревообробного підприємництва має бути закладений принцип пріоритетності ресурсозбереження, що дасть можливість розширити перелік методів та технологій утилізації лісосічних відходів та відходів деревообробки і лісопилення, а також мінімізувати втрати лісосировини у всіх фазах лісопродуктового ланцюга.

Аотримання даного принципу має передбачати використання франчайзингових, бенчмаркінгових, реінжинірингових та аутсорсингових бізнес-технологій, що дасть можливість використати передовий іноземний досвід застосування порубкових решток та інших складових деревних відходів у виробництві лісопродукції, перепрофілювати основні бізнес-процеси у переробних підрозділах суб'єктів лісогосподарського підприємництва в сторону економії лісосировини, залучати стороні організації для здійснення проєктів утилізації лісосічних відходів та відходів деревообробки і лісопилення.

Сьогодні внаслідок збитковості заготівлі лісосічних відходів та порубкових решток, які утворюються у місцях проведення рубок, значні обсяги такої неліквідної деревини або спалюються, або піддаються гниттю. Це суперечить пріоритетам боротьби з глобальним потеплінням, а постійні лісокористувачі втрачають потенційно можливі додаткові відходи. Такі деревні відходи виступають цінною сировиною для виробництва паливних продуктів, що можуть слугувати певною альтернативою тра- 
диційним видам мінерального палива для домогосподарств та об'єктів комунальної інфраструктури сільських населених пунктів, але за умови надання державою фінансових переференцій.

Такі преференції зроблять діяльність щодо заготівлі та утилізації деревних відходів прибутковою, що стане дієвим каталізатором поширення практики виробництва паливних деревних продуктів як на базі державних лісогосподарських підприємств, так і на базі суб'єктів деревообробного підприємництва. Тому постійні лісокористувачі та суб'єкти деревообробного підприємництва мають закласти в основу діяльності, спрямованої на нарощення обсягів виробництва паливних пелет та гранул, принцип енергетичної доцільності. Саме виконання такого принципу сприятиме не лише утилізації матеріально-речової субстанції деревних відходів (лісосічних відходів та відходів деревообробного виробництва), а й стимулюватиме лісокористувачів здійснювати розширення посівних площ лісових та сільськогосподарських культур енергетичної спрямованості. Вирощування названих культур розширить ресурсну базу виробництва паливних деревних ресурсів і фактично забезпечать формування повноцінного біоенергетичного сегменту лісового сектора, що стане вагомим чинником підвищення конкурентоспроможності лісогосподарського та деревообробного виробництва.

Процеси інтернаціоналізації також охопили і глобальні лісопродуктові ланцюги, тому входження національного лісового сектора у світогосподарський лісівничий простір вимагає імплементації визнаних світовою спільнотою регламентів та стандартів екологічно орієнтованого лісогосподарювання, що передбачає використання широкого спектра форм та методів організації лісівничої діяльності, а також залучення деревної та недеревної складових лісоресурсного потенціалу у відтворювальний процес. Запорукою прискорення процесів інтеграцї̈ Украӥни у світогосподарський лісівничий простір стане дотримання вимог принципу імплементації кращих практик лісового менеджменту країн ЄС у практику вітчизняного лісогосподарювання. В останні роки цей процес суттєво активізувався, що у середньостроковій перспективі дасть можливість на порядок підвищити рівень конкурентоспроможності національного лісового сектора у світогосподарському масштабі.

Аоповненням принципу імплементації кращих практик лісового менеджменту країн ЕС є принцип дотримання вимог цифрової транс- формації, що знайшло свій прояв в усесторонньому запровадженні засобів електронного обліку деревини та лісопродукції, сертифікації продукції, діджиталізації системи управління лісогосподарським виробництвом та переробними ланками лісового сектору, що створює умови для просування суб'єктів лісового сектора в глобальні лісопродуктові ланцюги, а в нинішніх умовах це запорука підвищення конкурентоспроможності. Цифрова трансформація лісового сектора дасть можливість оптимізувати трансакційні і трансформаційні витрати лісогосподарських підприємств та деревообробних виробництв і прискорити процеси прийняття управлінських рішень стосовно диверсифікації лісопродуктових ланцюгів і їх переорієнтації на ланцюги із замкненими циклами.

\section{ВИСНОВКИ І ПЕРСПЕКТИВИ ПОДАЛЬШИХ РОЗВІДОК}

Забезпечення прискорених темпів зростання рівня конкурентоспроможності лісового сектора потребує при проєктуванні конкретних механізмів врахування особливостей побудови лісопродуктових ланцюгів та дотримання комплексу принципів, що дають змогу зберегти максимальну асиміляційну місткість територій концентрації лісоресурсних благ та максимізувати валову додану вартість у сировинній та переробній ланці. Такими особливостями виступають: значний часовий лаг між посадкою лісу та його стиглістю; прогнозованість сировинної бази розвитку переробної ланки лісового сектора, що випливає з даних лісовпорядкування та моніторингу лісів; вагомість лісів у забезпеченні еколого-економічної стабільності територіальних утворень та стійкості біогеоценозів; багатокомпонентна структура лісопродуктових ланцюгів (лісове господарство, деревообробка, лісохімія, целюлозно-паперова промисловість). Водночас забезпечення конкурентоспроможності лісового сектора на еколого-економічних засадах має базуватися на дотриманні суб'єктами лісогосподарського та деревообробного виробництва комплексу принципів: невиснажливості, розширеного відтворення лісоресурсного потенціалу, еколого-економічної рівноваги, комплексності, інноваційної спрямованості, галузевої еквівалентності, пріоритетності ресурсозбереження, енергетичної доцільності, імплементації кращих практик лісового менеджменту країн ЕС у практику лісогосподарювання, дотримання вимог цифрової трансформації, компліментарності. Саме ці принципи мають бути враховані при формуванні національної лісової політики та держав- 
ної промислової політики в частині стимулювання розвитку переробних ланок лісового сектора.

\section{$\Lambda$ ітература:}

1. Андрійчук I.B., Пінчук I.P. Теоретикометодологічні засади оцінки конкурентоспроможності лісогосподарських підприємств. Причорноморські економічні студії. 2019. Вип. 37. С. 66-70.

2. Валінкевич Н. Модернізація як стратегічна конкурентна перевага розвитку підприємства. Конкурентоспроможність національної економіки: Матеріали XVII Міжнародної науково-практичної конференції, 5-6 жовтня 2017 р. К., 2017. C. 151-155.

3. Аобровольська Е., Покотильська Н. Стан та тенденції розвитку лісокористування. Причорноморські економічні студії. 2021. Вип. 63. C. 79-83.

4. Аубина М., Зінкевич О. Теоретичні аспекти функціонування та розвитку лісового господарства в Україні. Бізнес Інформ. 2020. № 2. C. 187-192.

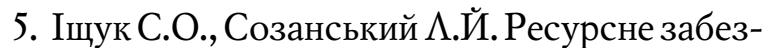
печення деревообробних виробництв України: міждержавні і міжрегіональні порівняння. Регіональна економіка. 2019. № 3 (93). С. 145-154.

6. Фітісов А. Теоретичні основи формування системи екологічного менеджменту у лісовому господарстві. Вісник ЖНАЕУ. 2017. № 1 (59). T. 2. С. $181-184$.

7. Формування стратегічних пріоритетів розвитку лісопромислового комплексу України: монографія / М.О. Кизим, І.В. Ярошенко, B.Є. Хаустова, I.О. Губарєва. Харків: ФОП $\Lambda$ ібуркіна $\Lambda$. М., 2019. 476 с.

\section{References:}

1. Andrijchuk, I.V. and Pinchuk, I.R. (2019), "Theoretical and methodological principles of assessing the competitiveness of forestry enterprises", Prychornomors'ki ekonomichni studii, vol. 37, pp. 66-70.

2. Valinkevych, N. (2017), "Modernization as a strategic competitive advantage of enterprise development", Konkurentospromozhnist' natsional'noi ekonomiky: Materialy KhVII Mizhnarodnoi naukovo-praktychnoi konferentsii [Competitiveness of the National Economy: Proceedings of the XVII International Scientific and Practical Conference], Kyiv, Ukraine, 5-6 October, pp. 151-155.

3. Dobrovol's'ka, E. and Pokotyl's'ka, N. (2021), "Status and trends in forest development", Prychornomors'ki ekonomichni studii, vol. 63, pp. 79-83.

4. Dubyna, M. and Zinkevych, O. (2020), "Theoretical aspects of the functioning and development of forestry in Ukraine", Biznes Inform, vol. 2, pp. 187-192.

5. Ischuk, S.O. and Sozans'kyj, L.J. (2019), "Resource provision of woodworking industries in Ukraine: interstate and interregional comparisons", Rehional'na ekonomika, vol. 3 (93), pp. 145-154.

6. Fitisov, A. (2017), "Theoretical bases of formation of system of ecological management in forestry", Visnyk ZhNAEU, vol. 1 (59), no. 2, pp. 181-184.

7. Kyzym, M.O. Yaroshenko, I.V. Khaustova, V.Ye. and Hubarieva, I.O. (2019), Formuvannia stratehichnykh priorytetiv rozvytku lisopromyslovoho kompleksu Ukrainy [Formation of strategic priorities for the development of the timber industry of Ukraine], FOP Liburkina L.M., Kharkiv, Ukraine.

Стаття надійшла до редакиії 04.10.2021 p.

\section{ПЕРЕАП ААТА}

ВИААННЯ МОЖНА ПЕРЕАПААТИТИ З БУАЬ-ЯКОГО МІСЯЦЯ!

- ЧЕРЕЗ РЕААКЦІЮ (ТЕА. 458-10-73);

- ЧЕРЕЗ АП "ПРЕСА"

(У КАТААОЗІ ВИААНЬ УКРАЇНИ);

— ЧЕРЕЗ ПЕРЕАП ААТНI АГЕНТСТВА 